\author{
UNIVERSIDADE DE SÃO PAULO \\ ESCOLA DE COMUNICAÇÕES E ARTES \\ PROGRAMA DE PÓS-GRADUAÇÃO EM ARTES CÊNICAS
}

TATIANA MELITELLO WASHIYA

Temporalidades em dança e suas dramaturgias do corpo

Versão original

São Paulo

2019 
TATIANA MELITELLO WASHIYA

\section{Temporalidades em dança e suas dramaturgias do corpo}

\section{Versão Original}

Tese apresentada ao Programa de Pós-Graduação em Artes Cênicas da Escola de Comunicações e Artes da Universidade de São Paulo para a obtenção do título de Doutora em Artes.

Área de concentração: Texto e Cena

Orientadora: Profa. Dra. Maria Helena Franco de Araujo Bastos

São Paulo 
Autorizo a reprodução e divulgação total ou parcial deste trabalho, por qualquer meio convencional ou eletrônico, para fins de estudo e pesquisa, desde que citada a fonte.

Catalogação na Publicação

Serviço de Biblioteca e Documentação

Escola de Comunicações e Artes da Universidade de São Paulo

Dados inseridos pelo(a) autor(a)

Washiya, Tatiana Melitello

Temporalidades em dança e suas dramaturgias do corpo /

Tatiana Melitello Washiya ; orientador, Maria Helena

Franco de Araujo Bastos. -- São Paulo, 2019.

$172 \mathrm{p}$.

Tese (Doutorado) - Programa de Pós-Graduação em Artes

Cênicas - Escola de Comunicações e Artes / Universidade de São Paulo.

Bibliografia

Versão original

1. dança contemporânea 2. tempo e temporalidades 3 .

dramaturgia 4. corpo I. Franco de Araujo Bastos, Maria

Helena II. Título.

CDD 21.ed. - 700 
Nome: WASHIYA, Tatiana Melitello

Título: Temporalidades em dança e suas dramaturgias do corpo

Tese apresentada ao Programa de Pós Graduação em Artes Cênicas da Universidade de São Paulo para obtenção do título de doutora em Artes.

Aprovada em:

Banca Examinadora:

Prof.(a) Dr.(a).

Instituição:

Julgamento:

Prof.(a) Dr.(a).

Instituição:

Julgamento:

Prof.(a) Dr.(a).

Instituição:

Julgamento:

Prof.(a) Dr.(a).

Instituição:

Julgamento:

Prof.(a) Dr.(a).

Instituição:

Julgamento: 
Dedico esta pesquisa ao meu pai Antonio Noboru Washiya (in memoriam), que faleceu no decorrer desta pesquisa, mas que sempre esteve comigo me apoiando com muito amor, sendo um importante guia na minha trajetória. Também quero homenagear minha mãe, Eliana Melitello Washiya, por todo amor, carinho e apoio. 


\section{Agradecimentos}

À minha orientadora Helena Bastos, pela atenção, convivência e apoio durante tantos anos de pesquisa.

À Profa. Dra. Geisha Fontaine, por toda a atenção e auxílio.

À Profa. Dra. Sandrine Dubouilh Frechet pela colaboração.

Aos integrantes do Laboratório de dramaturgia do corpo (LADCOR).

Ao meu parceiro Pablo Perosa.

Aos amigos Vagner Rodrigues, Peti Costa, Marcelo Castilha, Elisa Damazio, Cabelo, Lara Dau, Karina Ka, Lucia Yanez, Gulherme Pinto e Bebel de Barros.

À CAPES, pela bolsa de doutorado sanduíche no exterior.

O presente trabalho foi realizado com 0 apoio da Coordenação de Aperfeiçoamento de Pessoal de Nível Superior - Brasil (CAPES) - Código de Financiamento 001. 


\section{RESUMO}

A pesquisa investiga temporalidades em dança contemporânea a partir de três aspectos convergentes: o primeiro, de que as temporalidades se tecem em tramas pelo corpo por entendimentos espaçotemporais processados por esquemas cognitivos e experiências sensório-motoras nas trocas com o ambiente de existência. O segundo explora temporalidades pelas seleções, estratégias e organização de dados temporais numa perspectiva coreográfica a partir das referências das obras: Danças Passageiras (2013), Esculturas Breves (2015), Brevidades (2016) e Nó(s) (2016). Nessa confluência, a pesquisa agrega também os parâmetros temporais do movimento, tais como o fluxo, a repetição, o uníssono, a gravidade, a velocidade e a memória, com as obras So blue (2012), Fase: quatro movimentos para a música de Steve Reich (1982), Tempo 76 (2007) e Men Walking Down on the Side of a Building (1970). Os parâmetros temporais do movimento, compreendidos como um prisma de temporalidades, também são brevemente abordados no contexto de curso de dança. O terceiro aspecto engloba os anteriores para observar temporalidades em sua dimensão política, observando questionamentos temporais implicados no mercado cultural e no contexto histórico e sociocultural em que elas são elaboradas. A principal hipótese da pesquisa é que as temporalidades podem viabilizar uma dramaturgia do corpo em dança. O objetivo geral da pesquisa é compreender a ligação entre temporalidades e dança. O objetivo específico é analisar certas noções e estratégias temporais que, além de agirem como tessitura para a criação, permitem dramaturgias de dança. Para isso, são utilizados conceitos promovidos pelos pesquisadores(as) de dança André Lepecki (1997), Christine Greiner (2005), Geisha Fontaine (2004), Helena Katz (2005), Helena Bastos (2017), Laurence Louppe (2012), Maxine Sheets-Johnstone (1966), Rosa Hercoles (2010), entre outros autores. Esse campo teórico permite investigar a questão do tempo em dança pelo desenvolvimento do entendimento de que "temporalidades" correspondem ao processo de composição, organização e estruturação de toda uma concepção coreográfica.

PALAVRAS-CHAVE: Temporalidades; Dramaturgia; Dança; Corpo. 


\section{ABSTRACT}

This thesis analyses temporality in contemporary dance from three convergent aspects: the first covers temporalities as intertwined by the body through temporal experiences in environment. The second explores the understanding of temporality by selections, strategies and organization of temporal factors from a choreographic perspective, based on Brazilian dance works: Danças Passageiras (2013), Esculturas Breves (2015), Brevidades (2016) and Nó(s) (2016). In this confluence, the research also incorporates temporal parameters of movement, such as flow, repetition, unison, gravity, velocity and memory, analyzing the works: So blue (2012), Fase: four movements for the music of Steve Reich (1982), Tempo 76 (2007) and Men Walking Down on the Side of a Building (1970). Temporal parameters of movement as an aspect of temporality are also treated within this research in the context of dance course. The third aspect includes temporality on its political dimension, considering that temporal questions implies cultural market and sociocultural context in which they are elaborated.The main hypothesis of this research is that temporality enables a dramaturgy of the body on dance. The general goal of the research is to understand the connection between temporality and dance. The specific goal is to analyze temporal notions which enable the creation and dance dramaturgies. The research may use concepts promoted by dance researchers, such as: André Lepecki (1997), Christine Greiner (2005), Geisha Fontaine (2004), Helena Katz (2005), Helena Bastos (2017), Laurence Louppe (2012), Maxine SheetsJohnstone (1966), Rosa Hercoles (2010), among other authors. This theoretical field allows us to investigate the issue of time in dance, by developing the understanding that "temporality" corresponds to the process of composition, organization and structuring of a whole choreographic conception.

KEY-WORDS: temporality, dramaturgy, dance, body. 


\section{Sumário}

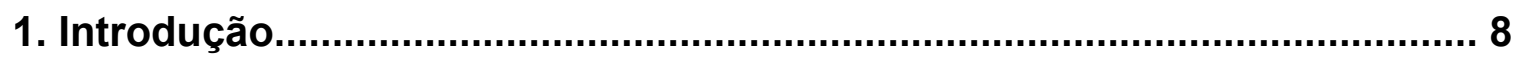

1.1 Estrutura do texto

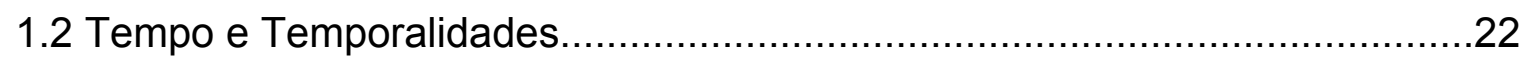

2. Temporalidades que viabilizam uma dramaturgia do corpo...................... 24

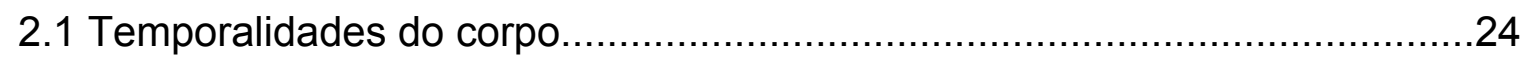

2.2 Temporalidades e dramaturgia das ações do corpo......................................39

2.3 Temporalidades implicadas na dramaturgia de dança e na coreografia........44

2.4 Dramaturgia que transborda os marcos de um texto dramático......................51

2.5 Temporalidades que surgem na e pela composição coreográfica..................59

3. Temporalidades percebidas em obras de dança...........................................67

3.1 Dramaturgia do instante em Danças Passageiras ......................................70

3.2 Dramaturgia das instalações coreográficas: Esculturas Breves e

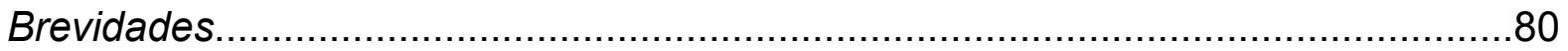

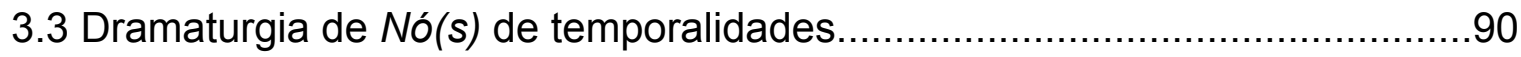

4. Parâmetros temporais na composição de procedimentos........................102

4.1 Parâmetros temporais do movimento......................................................102

4.2 A gravidade e a obra Men Walking Down on the Side of a Building ............105

$4.3 \mathrm{O}$ fluxo e a obra So blue........................................................................114

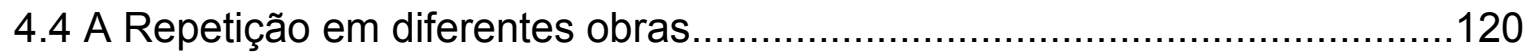

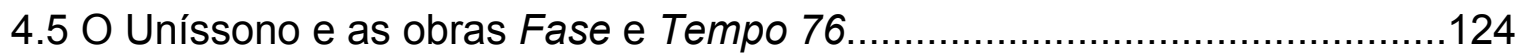

4.6 Parâmetros temporais do movimento no âmbito de curso de dança.............129

5. Temporalidades: questionamentos de um presente imediato......................138

5.1 Dimensão política de temporalidades em dança......................................138

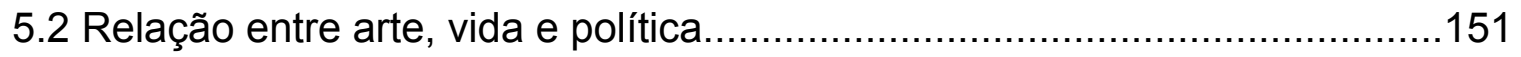

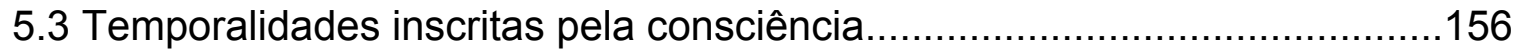

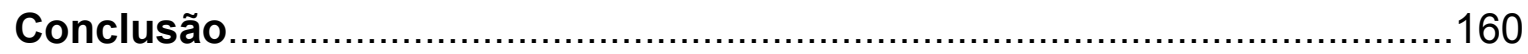

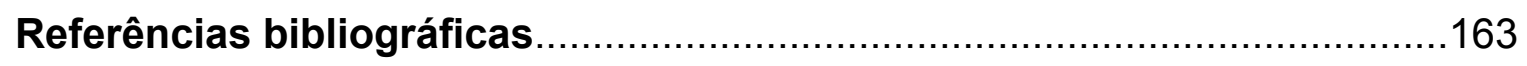




\section{Introdução}

A presente pesquisa realiza uma análise da ligação entre temporalidades e dança, investigando certas noções temporais que se estabelecem como tessitura de partida para a criação, com o entendimento de que esse prisma do tempo revela coerências e estratégias de uma organização coreográfica. Nesta investigação, desenvolvemos o entendimento de que a temporalidade corresponde ao processo de criação, composição e estruturação de procedimentos espaçotemporais que permitem a concepção de um pensamento artístico.

Esta investigação é uma continuidade da pesquisa de mestrado intitulada "Trajetórias Coreográficas: Composição entre corpo, espaço e cidade", desenvolvida sob a orientação da Prof. ${ }^{a}$ Dr. ${ }^{a}$ Helena Bastos, no Departamento de Artes Cênicas da USP, entre 2012 e 2014. A dissertação investigou certas elaborações espaciais organizadas pelo corpo na construção de uma dança por "trajetórias" que não apenas se referem a determinadas construções espaciais feitas em dança, mas também às organizações corporais que possibilitam essas construções de espaço.

A valorização da dimensão espacial na pesquisa de mestrado disparou, na investigação atual de doutorado, iniciada em 2015, o interesse em aprofundar as especificidades temporais no fazer em dança. Espaço e tempo estão invariavelmente ligados, contudo, a presente pesquisa se debruça sobre certas noções temporais em dança, a fim de estudarmos suas particularidades.

Refletir acerca das noções temporais em dança contemporânea implica algumas complexidades, porque há diversos aspectos do tempo em relação à dança. Neste sentido, a pesquisa aborda certos aspectos de temporalidades percebidas em dança, tais como: o modo como elas se estabelecem em tramas pelo corpo e como elas se constituem como um processo de criação, escolhas e organização de dados espaçotemporais; além disso, desenvolvemos também uma outra faceta de temporalidades que são os parâmetros temporais do movimento e uma dimensão política acerca dessa noção do tempo. Este viés de temporalidades é elaborado com a intenção de observarmos como tais temporalidades viabilizam uma dramaturgia do corpo em dança. 
Embora haja procedimentos espaço-temporais elaborados, por exemplo, pela iluminação, pela sonoplastia, por vezes por vídeo-imagens e outros elementos que possam entrar em jogo na concepção de uma dramaturgia, essa pesquisa foca na abordagem de dramaturgia composta pelas ações do corpo. Compreendemos que é a partir das ações corporais e das elaborações do movimento dançado que as coerências entre os demais elementos de uma concepção cênica são construídas permitindo uma dramaturgia, "através da temporalidade em que as relações de sentido se estabelecem e do espaço em que decorrem" (PAIS, 2016, p.103).

De acordo com a pesquisadora em dança e coreógrafa Helena Bastos (2003), as ações do corpo em dança correspondem a um mover com propósito. "O movimento é o fundamento do conhecimento e a dança ganha existência no corpo a partir de movimentos. É na ação que a dança constrói o corpo para que possamos entender o seu funcionamento e, consequentemente, conhecer" (BASTOS, 2003, p.52). Trata-se de ações produtoras de conhecimento que "estimulam conexões entre as estruturas de atividades corporais e operações cognitivas" (p.15).

A professora e dramaturgista de dança Rosa Hercoles colabora com a compreensão de que a dramaturgia das ações do corpo é composta por um tecido de relações coerentes, estabelecendo, por necessidades processuais, conexões com todos os elementos de uma concepção cênica. Isso porque a dramaturgia

trata da criação de algo que, apesar de compartilhar propriedades heterogêneas, apresenta uma organização que se encontra inseparavelmente conectada e não simplesmente agrupada. Podendo-se entender a dramaturgia, dentro de seu aspecto mais geral, como sendo a instância responsável pelo estabelecimento de tais conexões. (HERCOLES, 2005, p.18)

A partir desses entendimentos, investigamos como as temporalidades promovem estratégias de dança. A pesquisa desenvolve a hipótese de que as temporalidades podem viabilizar uma dramaturgia, com a compreensão de que as noções temporais criadas e combinadas dão a ver coerências e relações de sentido elaboradas em um pensamento artístico.

A pesquisa se debruça sobre as seguintes questões: $O$ que seria temporalidades em dança? Que relações acontecem entre essa noção temporal e o fazer coreográfico? As temporalidades poderiam viabilizar uma dramaturgia do corpo? Como as temporalidades estão implicadas num contexto artístico 
contemporâneo? Como elas estão sendo abordadas por coreógrafos brasileiros no século XXI? Se as temporalidades se constituem como estratégias de criação que portam singularidades e questionamentos de nosso presente imediato, que dimensão política pode se imbuir nesta noção temporal?

Partindo do entendimento de que a elaboração de noções e questões temporais em uma criação acontece por um processo de combinação de temporalidades e que essa noção qualitativa do tempo implica questionamentos que revelam e expõem modos de criação artística, investigamos como este prisma do tempo está envolvido nas organizações corporais e como as temporalidades se constituem como um conjunto elaborado de procedimentos espaçotemporais que viabilizam um pensamento cênico.

Embora a questão temporal seja amplamente estudada em diversos campos, tais como a filosofia, as ciências sociais e cognitivas, há poucas publicações que tratam de especificidades temporais presentes no campo de conhecimento da dança, o que endossa a dificuldade de se pensar acerca dessa problemática.

Contudo, certos pesquisadores em dança colaboram para refletirmos em torno de temporalidades em dança e suas dramaturgias do corpo. Entre eles, localizamos as reflexões propostas pelas autoras: Christine Greiner (2005), Helena Katz (2005) e Helena Bastos (2017), que permitem observarmos como as temporalidades se constituem como tramas pelas e nas ações do corpo e como elas implicam uma consciência no qualificar modos de agir; as autoras Geisha Fontaine (2004), Laurence Louppe (2012) e Maxine Sheets-Johnstone (1966) tratam pontualmente do tempo em dança contemporânea; as autoras Ana Pais (2016), Marianne Kerkhove $(1997)$ e Rosa Hercoles $(2005,2010)$ tratam de dramaturgia, auxiliando na observação da relação entre temporalidades e ações do corpo como pensamento dramatúrgico; os autores André Lepecki (2016) e Bojana Kunst (2015) promovem uma dimensão política de temporalidades em dança. Todos esses autores nos inspiram a pensar temporalidades em dança.

A investigação acontece por processos de contaminação da dança pelos campos do conhecimento das artes cênicas, da filosofia e das ciências cognitivas, e pela perspectiva de que ação e conhecimento se dão numa mesma escala temporal. A pesquisa aborda questionamentos que possam ir além da restrição de princípios enquadrados por uma determinada disciplina, tendo como intuito que as fronteiras entre esses conhecimentos permaneçam porosas, se entrelacem nessa investigação 
com as minhas experiências como dançarina, coreógrafa e professora de dança contemporânea, e também com a observação de diferentes criações coreográficas.

A investigação é realizada com exemplos de temporalidades percebidas nas obras coreográficas: Danças Passageiras (2013), concebida pela coreógrafa brasileira Zélia Monteiro; Esculturas Breves (2015) e Brevidades (2016), concebidos pela coreógrafa brasileira Helena Bastos; e no processo de criação da coreografia Nó(s) (2016), do qual participei como coreógrafa e dançarina. Esses exemplos ajudam a observar como a criação de procedimentos espaçotemporais percebidos nesses trabalhos dão a ver os pensamentos articulados de tais obras.

A pesquisa aborda também parâmetros temporais do movimento como uma das facetas de temporalidades. Entre os parâmetros temporais do movimento, selecionamos a gravidade, o fluxo, a repetição e o uníssono para este estudo. A seleção desses parâmetros é observada também com os exemplos das coreografias: Men Walking Down on the Side of a Building (1970), da norteamericana Trisha Brown; So blue, da canadense Louise Lecavalier (2012); Fase (1982), da belga Anne Teresa de Keersmaeker e Tempo 76 (2007) da francesa Mathilde Monnier.

Essas coreografias permitem que observemos singularidades nos modos de criação, combinação de noções temporais e diferentes abordagens no tratamento de cada um destes parâmetros temporais do movimento. Além disso, todos os exemplos que a presente pesquisa destaca dessas obras coreográficas também colaboram para observarmos a inviabilidade de definir uma única temporalidade em dança. Isso porque, além de as temporalidades se concretizarem de modo relacional, a área de conhecimento da dança contemporânea é um campo vasto e diversificado e se compõe justamente pelas distintas e infinitas organizações espaçotemporais.

Ademais, a investigação aborda dois cursos de dança ministrados por mim durante a pesquisa de doutorado. Essas experiências contribuem para observarmos como as temporalidades se desdobram de modo diferente na concepção de uma obra coreográfica e no que tange a um curso de dança, sob o viés do estudo dos parâmetros temporais do movimento.

Os entendimentos de temporalidades e a seleção dos parâmetros temporais do movimento abordados na presente pesquisa foram também desdobrados de acordo com o laboratório de dança, com o estágio realizado em agosto de 2017 a 
maio de 2018, pelo Programa de Doutorado Sanduíche, no Departamento de Artes da Universidade Bordeaux Montaigne, na França, com a supervisão da pesquisadora em dança e autora do livro "Les danses du temps" (2004), Geisha Fontaine $^{1}$.

Embora a presente pesquisa trate de diversas referências de dança, não pretendemos realizar uma abordagem historiográfica. Além disso, este estudo acerca das questões temporais em dança contemporânea está circunscrito num contexto ocidental. Buscamos tratar de temporalidades como um processo de elaboração de questões espaçotemporais que agem como tessitura de partida para as problemáticas artísticas de uma dramaturgia do corpo.

$\mathrm{Na}$ contramão de uma imagem retilínea, contínua e uniforme do tempo cronológico medido por fatores externos como relógios e calendários, a pesquisa desenvolve o termo temporalidades como um prisma do tempo que indica modos qualitativos de agir, elaborados pelas ações do corpo.

A pesquisa aborda um entendimento do corpo que se co-implica na ação que cria, corpo sujeito de cognição $^{2}$ e de percepção $^{3}$, que constrói relações espaçotemporais e incorpora entendimentos por seu processo sensório-motor. Temporalidades criadas por um processo cognitivo do corpo, o qual, por sua vez, "apreende e incorpora entendimentos espaciais e temporais na relação com o seu ambiente de existência" (KATZ; GREINER, 2005). Ou seja, trata-se de temporalidades que implicam espaço e espacialidades corporais. São temporalidades que se concretizam pelo corpo e no corpo que as constrói, de acordo com as suas experiências no ambiente. Dessa forma, o desafio de pensar relações temporais imbricadas na dança envolve complexidades que impossibilitam

\footnotetext{
${ }^{1}$ Doutora em filosofia da arte, Geisha Fontaine é coreógrafa da companhia Mille Plateaux Associés e presidente da Associação de Pesquisadores em Dança (l'aCD) de Paris.

2 "Etimologicamente, o termo cognição tem origem em cognoscere, significando adquirir conhecimento. Quando se diz que um sistema é cognitivo, diz-se que ele é capaz de conhecer, ou seja, de aprender. [...] Em princípio, o homem não apenas sabe como sobreviver e realizar certas tarefas aprendidas, mas também é capaz de aprender a aprender, de refletir sobre suas ações, resolver problemas complexos, inventar novos dispositivos técnicos, lidar com símbolos, criar cultura, escrever, dançar, criar e atuar na linguagem, tem capacidade de teatrar, de desenhar, entre outras ações. Enfim, a cognição humana possui complexidade ímpar, podendo ser estudada sob diversas perspectivas e contextos." (RIBEIRO, 2015, p. 27).

3 "A percepção é uma ação cognitiva elaborada pela experiência sensório-motora, com a qual os sentidos são continuamente selecionados no cérebro por sinais ligados à ação em curso. A percepção é elaborada segundo as possibilidades de cada corpo, fisiológicas, emocionais, culturais, em função da ação que cada pessoa põe em curso, a depender de sua história passada" (BERTHOZ, 2005).
} 
que a ideia de temporalidades seja dissociada do corpo. Aliás, é o corpo que possibilita essa noção de tempo.

Abordamos temporalidades que denotam um tempo plural, provisório e finito, correspondente à experiência humana. Um aspecto do tempo que é poético e singular, pois está relacionado às experiências, à consciência e à subjetividade de um indivíduo em coexistência com os outros pelo seu estar no mundo. As experiências no ambiente de existência desse corpo possibilitam a seleção e organização dos materiais espaçotemporais de uma obra. E, nesse sentido, o corpo é um elemento fundamental para esta pesquisa, porque ele atua como agenciador de sentidos para as estruturas artísticas que cria.

Com esse entendimento, esta investigação se debruça sobre temporalidades que implicam a consciência e as experiências de um indivíduo. Temporalidades que só existem a partir da percepção ${ }^{4}$ e que possibilitam a organização e a singularidade de uma dança. Elas envolvem as transformações do meio de existência onde esse corpo vive, uma noção de tempo em dança que está relacionada às potencialidades subjetivas da vida em sociedade. Ou seja, o ambiente cultural, biológico, contextual desse corpo é o que possibilitará essas temporalidades.

As temporalidades compostas pelas próprias tramas do corpo podem ser percebidas pelas diferentes experiências de passagem do tempo no ambiente de existência (JOHNSON, 2007), como, por exemplo, quando calculamos o tempo de corrida ao atravessar uma avenida. As noções de tempo incorporadas e apreendidas pelo corpo no ambiente de existência se relacionam a outras temporalidades que são construídas por um processo de agenciamento de procedimentos espaçotemporais elaborados numa criação artística.

"Se a dança tem forças que são específicas, é antes de tudo porque ela está relacionada aos dados temporais" (FONTAINE, 2004, p. 7). Tanto os entendimentos espaçotemporais elaborados por um corpo em relação ao ambiente em que esse vive quanto uma configuração de dados espaçotemporais voltada a uma proposição

\footnotetext{
${ }^{4}$ Segundo o catedrático de fisiologia da percepção do Collège de France, Alain Berthoz (2005), "a percepção é multissensorial, o cérebro escolhe, seleciona continuamente os sentidos utilizados em função da ação em curso e dos resultados esperados, que ele influencia e predetermina a sensibilidade dos receptores por sinais ligados à ação em curso ou extraídos da memória das ações passadas" (BERTHOZ, 2005, p. 29). Ele explica que a percepção é uma ação cognitiva elaborada pela experiência sensório-motora, na qual os sentidos são continuamente selecionados no cérebro por sinais ligados à ação em curso. A percepção é elaborada segundo as possibilidades de cada corpo, fisiológicas, emocionais, culturais, em função da ação que cada pessoa executa, a depender de sua história passada.
} 
cênica apresentam temporalidades que concretizam uma dramaturgia do corpo em dança.

$\mathrm{Na}$ construção de uma dança, modos qualitativos de agir são elaborados a partir da experiência, da consciência das sensações cinestésicas (JOHNSTONE, 1966), da subjetividade que encontra vias de especificação pelos processos de produção social (GUATTARI; ROLNIK, 1996) e da percepção como uma ação que põe em curso a memória e as expectativas esperadas (BERTHOZ, 2005). A criação em dança implica uma "corporeidade temporalizada que encontra vias de especificação por uma força motora ininterrupta colocada em jogo na coreografia" (BERNARD, 2001). Nesse sentido, ela não é estruturada de modo previsível, de sucessão ou continuidade linear temporal em que um evento $A$ necessariamente determine um evento $B$. As temporalidades implicam diversas relações espaçotemporais, e essa noção temporal "transforma o tempo objetivo dos relógios" (GIL, 2001). São temporalidades que correspondem a um contexto histórico e cultural de acordo com o ambiente em que elas se processam, se constituem como produção de diferenças, atuando de modo sociopolítico e estético como material de mudança (KUNST, 2012).

Os questionamentos explorados na pesquisa partem do entendimento de que temporalidades correspondem ao processo de composição, de organização e de estruturação de toda uma peça de dança, da sua construção à sua apresentação. As temporalidades, percebidas como um processo de criação de qualidades temporais, implicam um qualificar, um modo de agir. Quando qualificamos algo, identificamos uma precisão, uma urgência e uma singularidade: trata-se de temporalidades que denotam questionamentos específicos. Além disso, à medida que as noções temporais de um trabalho vão sendo exploradas, elas se desdobram em novas percepções temporais. O que queremos dizer é que o reconhecimento das qualidades temporais abre espaço a novas ressignificações e potencialidades no tratamento de uma organização de dança.

Nesse sentido, a presente pesquisa aborda temporalidades como um aspecto do tempo que denota qualidades espaçotemporais construídas pela e nas ações do corpo. Essas qualidades envolvem uma singularidade no que tange a diversas bifurcações e complexidades segundo a cultura, época, vivências e o ambiente em que elas se manifestam.

Cada criação coreográfica articula um modo qualitativo de lógicas e 
conexões entre os elementos a partir das ações do corpo, ações promovidas pelas experiências e percepções articuladas simultaneamente com as memórias e expectativas futuras deste corpo. Temporalidades que elaboram um presente composto de passados e projeções futuras, noções temporais que portam "singularidades na expressão de um evento" (LEPECKI, 2016), de acordo com seu contexto de existência.

Diferentemente do tempo quantitativo, cronológico e linear determinado por mecanismos externos, como relógios e calendários, as temporalidades indicam modos provisórios do corpo e do movimento de articularem convergências, divergências, sobreposições e simultaneidades de diversas elaborações temporais em uma estrutura artística.

Compreendemos que essas temporalidades compostas pelo corpo também permeiam outras linguagens e formatos artísticos além da dança. Segundo o autor Michel Bernard, "a temporalidade, trama de nossa corporeidade" (2001, p.14), convida o artista à elaboração de uma estética sem restrições em um trabalho artístico, sem fronteiras tanto no que se refere a um determinado domínio artístico, quanto a exigências normativas de uma necessidade social e de obstáculos institucionais. Para ele, "a arte é, por essência, nômade" (p.22) 5 . De acordo com o autor, a condição da arte não é encerrada por um valor próprio e nem por uma norma a priori, mas, isto sim, por um desenvolvimento no qual ela se articula e que interfere necessariamente em outras linguagens artísticas, em vez de se modular por uma segregação.

Porém, cada especificidade artística apresenta uma singularidade. Assim, podemos nos perguntar se existem temporalidades características da dança contemporânea.

Embora a expressão "dança contemporânea" seja "problemática"6, por se tratar de um termo bastante amplo e diversificado, ela corresponde às fronteiras cada vez mais sutis e fluídas entre as linguagens artísticas. Isso porque ela teve um

\footnotetext{
5 Tradução nossa a partir do original: "l'art est, par essence, nomade".

${ }^{6}$ Segundo a dançarina, doutora em filosofia da arte e professora da Universidade Paris $\mathrm{V}$, Sylvie Crémézi, "a palavra dança em todas as línguas europeias 'danza', 'dance', 'tanz', é derivada da raiz Tan que em sânscrito significa 'Tensão'. Quanto à palavra 'contemporânea', tomada nela mesma, significa simplesmente: 'que pertence ao tempo presente', uma vez que cada período supõe uma nova relação entre a época e a expressão. Mas atualmente, a expressão 'dança contemporânea' é mais problemática porque ela disputa frequentemente com a 'dança moderna' ou 'dança pósmoderna'." Tradução nossa a partir do original: "Le mot de danse dans toutes les langues européennes 'danza', 'danse', 'tanz', dérive de la racine Tan qui en sanskrit signifie 'Tension'. Quant
} 
avanço considerável no século $X X$ com crescimento da colaboração de campos do conhecimento como a história da arte, a filosofia, as ciências humanas e cognitivas, além do interesse por práticas somáticas e artigos especializados do meio acadêmico (LOUPPE, 2007, p.8).

Ao citar a pesquisadora Geisha Fontaine (2016), Louppe (2007) afirma que nos estudos de Fontaine "encontramos as armadilhas do tempo. O tempo como dimensão da história onde o evento corporal nunca cessa de recriar sua própria cena" (p.35). Para além disso, ela observa que a multiplicidade nas abordagens espaçotemporais com relação às escolhas do dançarino, bem como o risco artístico dos processos criativos, são características percebidas na dança contemporânea a partir dos anos 1960 na França. Segundo ela, a dimensão contemporânea da dança "encontra-se em uma abordagem crítica, ressoa com outras artes e demonstra multiplicidades de abordagens de criação" (FONTAINE, 2016) ${ }^{8}$.

Assim, explorar também o fator temporal dispara infinitas possibilidades de criação em dança contemporânea, campo do conhecimento no qual o corpo provoca mudanças. Segundo Sally Banes (2002), os coreógrafos trouxeram novas proposições e investigações sobre tempo, espaço, corpo e dança, abraçando diversas artes nos anos 1960. Outras proposições incorporadas à natureza da dança também entraram em questão, como jogos e ações simples, por exemplo, andar e correr: "essa abertura de fronteiras da dança foi uma ruptura com a dança moderna, que era qualitativamente diferente nas questões de tempo, espaço e corpo" 9 (BANNES, p.47).

A partir do século $X X$, o fluxo de procedimentos espaçotemporais entre os campos do conhecimento, tais como dança, teatro, música e artes visuais,

au mot 'contemporain', pris en lui-même, il signifie tout simplement : 'qui appartient à l'époque présente, au temps présent', puisque chaque période suppose une nouvelle relation entre l'époque et l'expression. Mais aujourd'hui, l'expression 'danse contemporaine' est plus problématique car elle rivalize souvent avec celle de 'danse moderne' ou 'modern dance' ou même 'post-modern dance'. (1997, p. 11).

7 "On retrouve ici les rets du temps à quoi Geisha Fontaine consacre son étude. Le temps comme dimension de l'Histoire où l'évènement corporel ne cesse de recréer sa propre scène". (2007, p.35).

${ }^{8}$ Disponível em: http://www.milleplateauxassocies.com/ouvertures/conferences/ Conferência em: 19/01/2016, em CNDC d'Angers. Acesso em: 21 mar. 2017.

${ }^{9}$ Tradução nossa a partir do original: "The problem of defining dance for the early postmodern choreographers was related to the inquiries into time, space, and the body, but extended beyond them, embrancing the other arts and asserting proposition about the nature of dance. [...] This opening of the borders of dance was a break from modern dance that was qualitatively different from issues of time, space and the body". 
contribuíram tanto para a expansão de linguagens artísticas quanto para os diversos atravessamentos abordados por instalações, espetáculos multimídia e performances, por exemplo, que se multiplicam e se expandem no contexto artístico atual. É nessa situação que o convívio e a diversidade de temporalidades parecem instigar cada vez mais dançarinos e coreógrafos contemporâneos.

Compreendemos que o campo de conhecimento da dança lida com processos de contaminação com ênfase nessa linguagem; além disso, há diversas estratégias que são exploradas no campo da dança. Por exemplo, abordamos o parâmetro espaçotemporal da gravidade e observamos diferentes modos nos quais ela é explorada nos exemplos que citamos nesta pesquisa.

Atualmente, observamos coreografias que utilizam textos, palavras, artes visuais e demais materiais que carregam lógicas temporais advindas de outras linguagens artísticas, e que frequentemente permeiam um espetáculo de dança. Porém, mesmo um texto, quando trabalhado no campo da dança, não terá o mesmo sentido do que quando inserido no teatro, por exemplo. Os procedimentos espaçotemporais construídos ao longo de um processo de criação por um corpo situado no campo da dança parecem ultrapassar os limites entre um espetáculo de dança, teatro ou performance. Os procedimentos temporais de cada um desses formatos se misturam e se entrelaçam cada vez mais enquanto proposta, que, a depender da situação, pode ser de dança, de performance ou teatro.

Nesse sentido, entendemos que as temporalidades em dança contemporânea têm se expandido a partir do século $X X$ até os dias de hoje. Atualmente, testemunhamos um aumento de complexidades, de sobreposições e de simultaneidades de diferentes qualidades espaçotemporais nas abordagens de criação em dança. As temporalidades - mesmo as preparadas pelo corpo no ambiente da dança - parecem ultrapassar a fronteira de uma estrutura de espetáculo de dança, ao serem apresentadas em diversos formatos e entrecruzadas com outras linguagens artísticas.

Assim, pensar as temporalidades e suas relações com a dramaturgia do corpo no campo da dança envolve diversos aspectos e irradia diversas características, as quais buscaremos abordar dentro dos limites da presente pesquisa. Trataremos de diferentes aspectos de temporalidades, observando como a criação das escolhas e a organização de procedimentos espaçotemporais se apresentam em diversos níveis na construção de uma dramaturgia do corpo. 
Temporalidades são elaboradas nessa investigação sob o aspecto do corpo, sob o viés dos procedimentos temporais que esse corpo constrói na composição de uma estrutura cênica. Trataremos também da dimensão política imbricada em tais questões e de certos parâmetros temporais do movimento recorrentes em dança. 


\subsection{Estrutura do texto}

No capítulo 2 em "Temporalidades que viabilizam uma dramaturgia do corpo", abordamos um entendimento de corpo composto por temporalidades. Essa perspectiva de temporalidades percebidas pelo viés do corpo é concebida pela teoria Corpomídia (KATZ; GREINER, 2005). Segundo essa teoria, o corpo é um processo coevolutivo com o seu ambiente de existência, sendo o sujeito de cognição aquele que incorpora e atualiza entendimentos espaçotemporais na relação com o outro e com os objetos, no meio em que vive. Abordamos também a noção de dramaturgia composta pelas ações do corpo, observando a etimologia da palavra drama: do grego, drao significa agir. Ademais, apontamos concepções de dramaturgia no campo da dança segundo alguns contextos históricos e culturais, como, por exemplo, o termo dramaturgia empregado como "a ação do dramaturgista" (FONTAINE, 2017) e como "relações de cumplicidades e sentidos no espetáculo" (PAIS, 2016). Traçamos uma relação com a dramaturgia que advém do teatro, e, atualmente, a ação do dramaturgista cada vez mais sendo realizada por processos coletivos. Tratamos do entendimento de temporalidades como o processo de composição e de estruturação de procedimentos temporais que permitem uma concepção de pensamento artístico. Quando falamos em composição, percebemos que ela não acontece de modo totalmente controlado - como, por exemplo, na perspectiva de composição controlada proposta pela coreógrafa Doris Humphrey -, mas sim dentro de uma concepção que talvez se aproxime da proposta do coreógrafo Merce Cunningham. Cunningham explora as temporalidades do acaso e do imprevisível em suas composições, levando em conta "processos de atualizações" (LEPECKI, 2011).

No capítulo 3 em "Temporalidades percebidas em obras de dança", abordamos temporalidades percebidas em Danças Passageiras, Esculturas Breves e Brevidades e Nó(s). Observamos como o cruzamento de diferentes procedimentos temporais permite uma dramaturgia e como a expansão de temporalidades colabora para os novos formatos de apresentação de dança.

No capítulo 4 em "Parâmetros temporais na composição de procedimentos", abordamos parâmetros temporais do movimento como uma das facetas de 
temporalidades em dança. Entre os parâmetros temporais do movimento, a presente pesquisa seleciona para o estudo o fluxo, o uníssono, a defasagem, a repetição, a velocidade e a gravidade. Compreendemos que tais parâmetros temporais do movimento participam de uma dramaturgia das ações do corpo em dança. Embora esses parâmetros apenas se concretizem de maneira relacional em cada processo, cada um deles apresenta certas características próprias. Com esse entendimento, buscamos esmiuçar os parâmetros selecionados na presente pesquisa, observando como eles se desdobram em diferentes procedimentos de obras coreográficas.

Os parâmetros temporais do movimento são ressignificados, como observamos no exemplo da exploração do uníssono na obra Tempo 76, da coreógrafa francesa Mathilde Monnier. Por vezes, há subversão de princípios próprios de um certo parâmetro, como veremos, por exemplo, com a gravidade subvertida na obra Men Walking Down on the Side of a Building, da coreógrafa norte-americana Trisha Brown. Há obras, por outro lado, nas quais cada parâmetro se evidencia como elaboração de um pensamento artístico, como é o caso do parâmetro temporal do fluxo, explorado na obra So Blue da coreógrafa canadanse Louise Lecavalier; outro exemplo é o uníssono e a repetição, elaborados na obra Fase: quatro movimentos para a música de Steve Reich, da coreógrafa belga Anne Teresa de Keersmaeker. Além desses exemplos, apontamos também outros pensamentos coreográficos acerca desses mesmos parâmetros temporais do movimento, com o intuito de observar como cada um deles pode se desdobrar de diversas maneiras em diferentes obras coreográficas.

No capítulo 5 em "Temporalidades: questionamentos de um presente imediato", abordamos uma dimensão política de temporalidades em dança, observando como as temporalidades implicam "singularidades" (LEPECKI, 2016), diferenças, "dissensos no compartilhamento de experiências comuns" e "modos de subjetivação" (RANCIĖRE, 2017, 2018). Temporalidades que participam de referências culturais, sociais e até institucionais, onde uma dança se desenvolve. Temporalidades que não implicam um espaço mensurável ou tempo objetivo dos relógios, mas que expandem potências de agir no encontro com o espectador porque são temporalidades que envolvem a consciência (GIL, 2001). Um aspecto político de temporalidades é observado no contexto brasileiro a partir dos acontecimentos político-econômicos do país, os quais, por sua vez, interferem nas condições de trabalho do dançarino e também em suas temporalidades, à medida 
que implicam discursos de descontinuidades, rupturas e suspensões. Abordamos, por fim, uma temporalidade da consciência que se conecta com as expectativas futuras e necessidades de um corpo, além de jogos imprevisíveis do imaginário (BERNARD, 2001). 


\subsection{Tempo e Temporalidades}

Tempo e temporalidades estão invariavelmente ligados, não se pode manter a presença de um sem o outro, pois o tempo só pode ser apreendido a partir de uma condição temporal: "o homem não consegue estudar o tempo se não a partir da sua própria temporalidade, da sua própria vida, das suas próprias angústias, das suas próprias sensações" ${ }^{10}$ (FILHO, 2016).

Tempo e temporalidades são elementos indissociáveis um do outro. Por exemplo, é no tempo de duração de um espetáculo de dança que são apresentadas as qualidades temporais, as ideias e coerências trabalhadas num processo de composição coreográfica. Porém, há diferenças entre tempo e temporalidades: "a temporalidade corresponde a um prisma do tempo" ${ }^{11}$ (FONTAINE, 2017).

Mesmo compreendendo que a ligação entre tempo e temporalidades seja estreita, a palavra temporalidade porta questionamentos e modos específicos de organizações temporais. Para tratar das questões temporais implicadas no fazer em dança, a pesquisa utiliza o adjetivo temporalidades, que denota "qualidade, estado ou condição do que é temporal estado do que é provisório" (HOUAISS, 2001, p. 2691), um aspecto do tempo que qualifica uma determinada maneira de agir. Ou seja, não pretendemos abordar nesta pesquisa o substantivo tempo, que indica "a ideia de presente, passado e futuro; período contínuo no qual os eventos se sucedem" (HOUAISS, 2001, p. 2690).

Segundo a Enciclopédia Einaudi (1993), os significados de "tempo/temporalidades" são descritos tanto pelo ordenamento dos acontecimentos segundo a sua sucessão temporal - o tempo físico e quantitativo, definido pelos relógios -, quanto pelas elaborações sensório-motoras. "A organização temporal dos comportamentos somáticos dos indivíduos - mas também da vida social - reproduz, pois, um traço essencial da história do tempo" (p. 68). A enciclopédia denota temporalidades como processos subjetivos e relacionais com o outro e com os

\footnotetext{
10 Palestra do filósofo Clóvis de Barros Filho "Tempo e Temporalidades". Disponível em: https://www.youtube.com/watch?v=yKwEKVpAo0c Acesso em: 12 nov. 2017. Publicado no Caderno Filosófico em 03 mar. 2016.

${ }^{11}$ FONTAINE, G. Entrevista à Tatiana Melitello. Bordeaux, 2017. Tradução a partir do original: "La temporalité correspond à un prisme du temps".
} 
objetos no mundo, implicando fluxo dos estados de consciência, de multiplicidade e variabilidade, diferentemente do tempo objetivo, quantitativo, homogêneo e mensurável pelos relógios.

A "concepção de tempo mais antiga e difundida na Antiguidade considera-o como uma ordem mensurável do movimento"12 (ABBAGNANO, 1963, p. 1135). O tempo que indica uma duração caracterizada por determinados períodos e medidas, como, por exemplo, um dia ou uma hora, implica um corpo que ocupa uma posição regular e que se move segundo períodos regulares. Ele caracteriza o fluxo contínuo de movimento dos corpos que se relacionam na medida em que uma coisa se sucede à outra.

Segundo o sociólogo alemão Norbert Elias (1998), o tempo determinado pelo relógio, instrumento físico padronizado pela sociedade, define o caráter instrumental do tempo por uma ordenação linear dos acontecimentos que envolve um "antes" e um "depois". Também implica o estabelecimento de uma relação no seio de uma única e mesma sequência de acontecimentos, entre o que se produz "mais cedo" e o que se produz "mais tarde".

Compreendemos o "tempo cronológico, da sucessão de dias, horas, momentos, período; época" (FERREIRA, 1972, p. 1164) por unidades que podem ser medidas por fatores externos - como, por exemplo, pelo mecanismo dos relógios e calendários -, segundo uma linha temporal de referências na qual os acontecimentos são mensurados em sequências temporais regulares, uniformes e contínuas.

\footnotetext{
12 "A definição de Aristóteles, o Tempo é o número do movimento segundo o antes e o depois [...], é a expressão mais perfeita dessa concepção, que identifica o Tempo com a ordem mensurável do movimento. Não é diferente o significado da definição dos estoicos [...] Na Idade Média, essa concepção do $T$. foi compartilhada por realistas e por nominalistas [...] Hobbes definiu o T. como imagem do movimento, na medida em que imaginamos no movimento o antes e o depois, ou seja, a sucessão [...] Descartes simplesmente repetia essa última, definindo o $T$. como número do movimento" (ABBAGNANO, 1998, p. 945).
} 


\section{Temporalidades que viabilizam uma dramaturgia do corpo}

\subsection{Temporalidades do corpo}

O entendimento de corpo abordado nesta pesquisa é vital para compreendermos como as temporalidades permitem uma dramaturgia do corpo. Isso porque $\mathrm{o}$ próprio corpo elabora temporalidades constantemente. $\mathrm{O}$ entendimento de corpo que norteia esta pesquisa é proposto pela Teoria Corpomídia criada em 2001 pelas pesquisadoras Helena Katz ${ }^{13}$ e Cristine Greiner ${ }^{14}$ (2005). Essa teoria permite compreender o corpo como um processo coevolutivo pelas constantes trocas com o outro no meio de existência. Embora essas trocas estejam implicadas nas permanências de elementos já configurados no corpo, os acontecimentos que ainda estão por vir promovem de modo ininterrupto atualizações cognitivas e novas percepções nas experiências espaçotemporais desse corpo. Isso implica um corpo que a todo momento é transformado pelas informações e toda transformação indica um processo temporal.

A teoria Corpomídia lida com a noção de mídia de si mesmo, diferentemente de um entendimento de corpo como recipiente, no qual as informações seriam armazenadas e depois devolvidas como um veículo de transmissão. Ou seja, contrária ao entendimento do corpo como um suporte unilateral de entrada e saída de dados, a teoria do Corpomídia afirma que os cruzamentos de informações biológicas e culturais são constantemente atualizados em relação às organizações já existentes desse corpo, através do sistema sensório-motor e nervoso, na relação entre o corpo e o ambiente.

\footnotetext{
${ }^{13}$ Helena Katz é pesquisadora de dança, professor doutora do Departamento de Linguagens do Corpo da PUC / SP e crítica de dança do jornal O Estado de São Paulo.

${ }_{14}$ Christine Greiner é pesquisadora de dança e professora doutora do Departamento de Linguagens do Corpo da PUC/SP.
} 
As informações do mundo são selecionadas para se organizar na forma de corpo-processo sempre condicionado pelo entendimento de que o corpo não é um recipiente, mas sim aquilo que se apronta nesse processo coevolutivo de trocas com o ambiente. (GREINER; KATZ, 2005, p. 130)

O corpo se transforma, apreende, incorpora conhecimentos por um fluxo constante de diferentes informações que são processadas no ambiente de existência, informações essas que invariavelmente transformam e modificam esse corpo. A concepção de que o corpo é um processo coevolutivo que apronta redes perceptuais, motoras e de aprendizado nas relações com o ambiente, proposta pela Teoria Corpomídia, possibilita pensar que temporalidades implicam espacialidades, pois, segundo essa Teoria, é na relação com o ambiente que elaboramos noções temporais. Em outras palavras, é com o espaço que se formam entendimentos de tempo.

\begin{abstract}
As relações entre o corpo e o ambiente se dão por processos coevolutivos que produzem uma rede de pré-disposições perceptuais, motoras, de aprendizado e emocionais. Embora corpo e ambiente estejam envolvidos em fluxos permanentes de informação, há uma taxa de preservação que garante a unidade e a sobrevivência dos organismos e de cada ser vivo em meio à transformação constante que caracteriza os sistemas vivos. [...] $\mathrm{O}$ corpo não é um lugar onde as informações que vêm do mundo são processadas para serem depois devolvidas ao mundo. [...] O corpo é - resultado desses cruzamentos, e não um lugar onde as informações são apenas abrigadas. É com esta noção de mídia de si mesmo que o corpomídia lida, e não com a ideia de mídia pensada como veículo de transmissão. (KATZ; GREINER, 2005, pp. 130-131)
\end{abstract}

O pesquisador Andrew Hewitt ${ }^{15}$ (2005) contribui com esse entendimento, explicando que, no exercício cotidiano no ambiente de existência, aprendemos por exemplo operações de equilíbrio e medidas espaçotemporais a partir dos referenciais que o corpo denota. Hewitt afirma que a vivência cotidiana no ambiente mobiliza em nós não apenas noções espaçotemporais, mas também incorporações e modos de agir, através de uma educação na qual aprendemos uma linguagem de expressão em meio à experiência social (2005, pp. 78-79). Nesse sentido, o termo coreografia utilizado por Hewitt ajuda a pensarmos o corpo implicado em sua prática

\footnotetext{
${ }^{15}$ Andrew Hewitt é professor de literatura comparada na Universidade da Califórnia, Los Angeles.
} 
social sob um viés estético-político, que desenvolveremos no último capítulo da presente pesquisa.

Outro pesquisador que colabora na reflexão sobre o corpo, espacialidades e temporalidades como elementos interdependentes (o que possibilita compreendermos temporalidades processadas pelo corpo através de esquemas cognitivos e experiências sensório-motoras desse corpo) é Mark Johnson ${ }^{16}$ (2007). Ele explica que compreendemos relações espaçotemporais por meio do movimento corporal e da percepção motora dos objetos nas experiências vividas. Esse entendimento é construído a partir do movimento do nosso corpo e das relações com os objetos no ambiente. Realizamos esquemas de imagens a partir das atividades sensório-motoras porque é nos movimentos espaciais que compreendemos como o tempo se "move" ou "passa". O autor afirma que a elaboração de metáforas, significados, qualidades, emoções, perceptos, imagens e estruturas imaginativas, realizadas por esquemas cognitivos ${ }^{17}$, abre espaço para relacionarmos informações e prepararmos conceitos, como noções temporais, por exemplo. Esse processo é formado pela experiência na interação do corpo com o ambiente, por meio de vivências atuais e possíveis.

As noções temporais são apreendidas no ambiente por temporalidades do corpo que não se processam por uma ação que sucede a outra. Cada qualidade de movimento nos oferece distintas passagens de tempo, diferentes temporalidades são construídas de modo provisório pelas ações corporais sem necessariamente haver uma relação linear entre essas ações.

Segundo Johnson, distintas qualidades temporais são realizadas nos diferentes modos de ação corporal: a produção de um movimento manifesta qualidades temporais dependendo de como o ato é performado. Ações como andar, correr, saltar ou andar na ponta dos pés oferecem distintas experiências de passagem temporal. Essa ideia auxilia na compreensão de que temporalidades são construídas de acordo com as diversas experiências de movimento trabalhadas em

\footnotetext{
${ }^{16}$ Mark Johnson é professor de Artes e Ciências do Departamento de Filosofia da Universidade de Oregon.

17 "Cognição é um tipo particular de ação: uma estratégia que envolve processos inconscientes e conscientes que são solicitados na avaliação e organização dos problemas práticos do mundo". Tradução nossa a partir do original: "cognition is a particular kind of action: a response strategy that apply some measure of forethought in order to solve some practical, real-world problem" (JOHNSON, 2007, p. 120).
} 
cada processo coreográfico. O autor cita o fluxo como uma das experiências qualitativas do tempo:

Contudo, quero conectar nossa consideração fenomenológica das qualidades do fluxo temporal com nossa habilidade de conceituar tempo e relações temporais. Pois, já em nossa percepção e movimento corporais, experimentamos essa correlação íntima entre movimento e mudança temporal, que é a base para algumas das maneiras pelas quais nós pensamos de forma mais abstrata sobre o tempo, e são precisamente as várias qualidades de diferentes movimentos que nos permitem conceituar diferentes experiências de passagem do tempo. ${ }^{18}$ (JOHNSON, 2007, p. 28)

Os escritos de Johnson, de Hewitt e a Teoria Corpomídia permitem compreendermos temporalidades do corpo como experiências processadas pelas relações que esse corpo estabelece com o seu ambiente. Situações e contextos relacionais permitem diferentes percepções espaçotemporais manifestas por distintas qualidades de movimentos, que, por sua vez, geram novas percepções. Essa noção de temporalidades diz respeito, portanto, ao presente, que é efetivamente sensório-motor. O corpo e suas relações espaçotemporais são dependentes. Temporalidades são produtoras de espacialidades, pois não estamos falando de um tempo ou de um espaço em geral, mas sim de temporalidades e espacialidades próprias a um corpo em movimento.

Trata-se de temporalidades que implicam um presente ancorado em diversas qualidades de movimento, tais como suas resistências, desacelerações e suspensões - uma ideia de tempo ligada ao corpo e ao seu peso em relação ao espaço.

Nesse sentido, a filósofa e pesquisadora em dança Marie Bardet ${ }^{19}$ (2012) nos leva a compreender temporalidades como um objeto de estudo privilegiado para o corpo em dança. Segundo ela, temporalidades se processam pelas ações do corpo nas suas escolhas espaçotemporais. Trata-se de temporalidades que têm o

\footnotetext{
${ }^{18}$ Tradução nossa a partir do original: "However, by way of anticipation, I want to connect our phenomenological account of the qualities of temporal flow with our ability to conceptualize time and temporal relations. For, already in our perception and bodily movement, we experience this intimate correlation of movement and temporal change that is the basis for some of the ways we think more abstractly about time, and it is precisely the various qualities of different movements that permit us to conceptualize different experiences of the passing of time".

${ }_{19}$ Marie Bardet é doutora em estética e filosofia contemporânea e professora de dança da Universidade Paris 8.
} 
presente como mediador, um presente que é constitutivo do movimento sensóriomotor, porque a dança se tece "entre perceber e fazer, uma temporalidade $\operatorname{singular"~}^{20}$ (p. 88), pelo movimento. A improvisação, por exemplo, lida com a temporalidade atrelada ao tempo real, ou seja, a um tipo de composição no qual o tempo presente é um elemento fundamental, pois é a partir dele que a emergência de novos movimentos pode acontecer no espaço-tempo da cena.

Nesse contexto, Bardet auxilia na compreensão de que a temporalidade se manifesta de modo singular e heterogêneo ${ }^{21}$, permitindo captar a atenção presente para os movimentos. Nos jogos dinâmicos do movimento dançado, a temporalidade emerge da duração heterogênea entre a memória corporal desse corpo, provida pela consciência, e as imprevisibilidades do presente, fatores que eliminam o esquema linear temporal de causa e consequência.

A temporalidade dos corpos em movimento pensada no cruzamento entre as práticas da dança e da filosofia, e em particular na leitura dos textos de Bergson, se redistribui radicalmente em uma heterogeneidade que deforma o esquema clássico de causa/consequência. ${ }^{22}$ (2012, p. 203)

Os escritos de Bardet acerca da temporalidade dos corpos se apoiam no pensamento pluralista das várias dimensões do tempo, elaborado pelo filósofo Henri Bergson (1859-1941). Para ele: "não há um ritmo único da duração; é possível imaginar muitos ritmos diferentes os quais [...] mediriam o grau de tensão ou relaxamento das consciências" (BERGSON, 1990, p. 171). Há uma duração elástica formada por um presente contraído de passados e futuros, em que a ação é inerente, ou seja, constitutiva do movimento sensório-motor do corpo.

Entre as simultaneidades, ocorrerá tudo o que se quiser. O tempo poderia acelerar-se enormemente, e mesmo infinitamente: nada teria

\footnotetext{
${ }^{20}$ Tradução nossa a partir do original: "Se precisa allí el àmbito de trabajo de toda danza que teje, en los limites entre percibir y hacer, una temporalidade singular de su efectuación".

${ }^{21}$ A palavra heterogêneo, no presente texto, indica variedade, de natureza variada. "Mesmo a mais básica das trocas de energia e/ou informação só acontece fora da homogeneidade plena. O tempo também desempenha um papel fundamental na identificação e no surgimento das diferenças. E quando aparece em movimento (fluxo) já anuncia a possibilidade do outro, porque todo sinal que ocorre em diferentes tempos se modifica" (KATZ; GREINER, 2015, pp. 17-18).

${ }^{22}$ Tradução nossa a partir do original: "A temporalidad de los cuerpos en movimiento pensada en el cruce entre las prácticas danzadas y filosóficas, y más en particular en la lectura de textos de Bergson, se redistribuye radicalmente en una heterogeneidad que deforma el esquema clássico de causa/consequencia."
} 
mudado para o matemático, para o físico, para o astrônomo. Profunda, no entanto, seria a diferença do ponto de vista da consciência. (BERGSON, 2006, p. 5)

Essa duração temporal invariavelmente implica um jogo simultâneo de múltiplas referências. Bergson (1968) explica que a duração temporal envolve a percepção dos momentos de nossas vidas relacionada ao ambiente. Isso abrange uma consciência apreendida dos múltiplos eventos situados nos diversos pontos do espaço. Mas essa consciência não diz respeito apenas a um indivíduo, e sim à relação, a um conjunto de consciências que os sujeitos partilham. Segundo ele, "somos capazes de realizar os movimentos do corpo em dois aspectos: como sensação muscular, eles fazem parte contínua da consciência, e como percepção visual, eles descrevem uma trajetória no espaço"23 (BERGSON, 1968, p. 48).

Para ele, a duração, mais do que uma imagem espacial, configura-se como uma imagem temporal da experiência do corpo. A duração é percebida como uma noção criadora elaborada tanto pela matéria, que para Bergson diz respeito ao corpo e ao espaço - "chamo de matéria o conjunto das imagens, e de percepção da matéria essas mesmas imagens relacionadas à ação possível de uma certa imagem determinada, meu corpo" (2010, p. 17) -, quanto pela memória, que, segundo o autor, indica "sobrevivência das imagens passadas, estas imagens irão misturar-se constantemente à nossa percepção do presente e poderão inclusive substituí-la" (2010, p. 69). Ou seja, uma ideia de duração que incorpora o instante da experiência do presente e a experiência adquirida, de tempos criados e estendidos que implicam a consciência.

\begin{abstract}
O presente real, concreto, vivido, aquele a que me refiro quando falo de minha percepção presente, este ocupa necessariamente uma duração. Onde portanto se situa essa duração? Estará aquém, estará além do ponto matemático que determino idealmente quando penso no instante presente? Evidentemente, está aquém e além ao mesmo tempo, e o que chamo 'meu presente' estende-se ao mesmo tempo sobre meu passado e sobre meu futuro [...] Donde concluo que meu presente consiste num sistema combinado de sensações e
\end{abstract}

\footnotetext{
${ }^{23}$ Tradução nossa a partir do original : "Il est donc bien vrai que le temps se mesure par l'intermédiaire du mouvement. Mais il faut ajouter que, si cette mesure du temps par le mouvement est possible, c'est surtout parce que nous sommes capables d'accomplir des mouvements nousmêmes et que ces mouvements ont alors un double aspect : comme sensation musculaire, ils font partie du courant de notre vie consciente, ils durent ; comme perception visuelle, ils décrivent une trajectoire, ils se donnent un espace".
} 
movimentos. Meu presente é, por essência, sensório-motor. (BERGSON, 1999, pp. 113-114)

De acordo com Bergson (2006), diferentemente de uma duração medida pela trajetória de um móvel, os dados espaçotemporais configurados pela própria ação do corpo agem como elaboração, criação e escolha. Para ele, a duração dessa temporalidade é concebida considerando a consciência do tempo vivido: essa duração "não é somente a experiência vivida; é também experiência ampliada" (DELEUZE, 1999, p. 31). Ela tem como característica "a novidade absoluta a cada instante, por isso é um processo contínuo de criação" (ABBAGNANO, 1963, p. 1139).

\begin{abstract}
Sermos criadores de nossas intenções, de nossas decisões, de nossos atos e, por isso mesmo, de nossos hábitos [...], trabalhamos continuamente na modelagem, como a matéria que nos é fornecida pelo passado e pelo presente, pela hereditariedade, pelas circunstâncias [...] não é necessário que dele tenhamos plena consciência, como tampouco o artista precisa analisar seu poder criador; ele deixa esse cuidado para o filósofo e contenta-se com criar. Em compensação, é preciso que o escultor conheça a técnica de sua arte e saiba tudo o que se pode aprender acerca dela: essa técnica concerne sobretudo àquilo que sua obra terá em comum com outras; é comandada pelas exigências da matéria sobre a qual ele opera e que se impõe a ele como a todos os artistas. (BERGSON, 2006, p. 108)
\end{abstract}

Bergson "não coloca mais o movimento do lado da duração", ele "descobre um tempo que é coexistência de todos os níveis de duração" (DELEUZE, 1992, p. 64). Com essa perspectiva, compreendemos que o corpo em dança lida com temporalidades entrecruzadas por um pensamento rizomático na organização de uma coreografia, pondo em jogo um fluxo de referências descontínuas e que aparecem de modo não previsível.

Nessas organizações, o movimento articula elementos do passado, do futuro e do presente, mas não por meio de uma linearidade sucessiva de informações, que segue de um ponto a outro reciprocamente, e sim por "uma direção perpendicular, um movimento transversal, que as carrega uma e outra, racho sem início nem fim, que rói suas duas margens e adquire velocidade no meio" (DELEUZE, 1995, p. 49). 
Essa reflexão possibilita pensarmos que as temporalidades do corpo são mobilizadoras de uma ideia, agem como criação, pois interligam passado, presente e futuro de modos entrecruzados. Nesse viés, a pesquisadora em dança Laurence Louppe $^{24}$ (2012) afirma que "a problemática do tempo é uma das grandes questões da dança contemporânea" (p. 149). O aspecto temporal em uma obra artística é fundamental, pois não é um elemento que constatamos localizar-se exteriormente a nós ou de modo pronto, ele é criado pelo corpo - portanto, é um constante fluxo de transformação desse mesmo corpo.

Assim, não tratamos de um tempo que se constitui por uma linha contínua, tal como o tempo cronológico. Diferentemente desse, o corpo na dança cria temporalidades de modo assimétrico, ou seja, esse corpo constrói e lida com um presente contraído de passados e futuros, um tempo fluído, em um trânsito entre essas temporalidades.

Para a coreógrafa, pesquisadora e doutora em filosofia da arte, Geisha Fontaine (2004), o corpo é percebido "como uma temporalidade provisória que produz outra temporalidade provisória: o movimento" 25 (FONTAINE, 2004, p. 11). De acordo com ela, o processo de elaboração de obras coreográficas depende das variações temporais instauradas, que ganham especificidade pelo trabalho corporal dos dançarinos.

Esse processo não é formado somente pelo ajuntamento de um elemento temporal a partir do anterior para o posterior. Segundo Fontaine ${ }^{26}$, a questão do tempo intervém sobre os modos de estruturação de uma peça coreográfica, sobre o movimento dançado, sobre as relações entre os dançarinos. Essas elaborações temporais se constroem durante o processo de criação e se revelam de diversas maneiras na concepção coreográfica. Os dados temporais podem se constituir como tema ou material para estratégias corporais e composicionais de uma dança, ou

\footnotetext{
${ }^{24}$ Laurence Louppe (1938 -2012) foi crítica e historiadora de dança especializada em estética da dança.

${ }^{25}$ Tradução nossa a partir do original: "je conçois le corps comme une temporalité provisoire produisant une autre temporalité provisoire: le mouvement."

${ }^{26}$ Conversa com Geisha Fontaine (2017). Tradução a partir do original: "la question du temps intervient sur les modes de structuration d'une pièce chorégraphique, sur le mouvement dansé et sur les rapports entre les danseurs. Ces élaborations temporelles se construisent lors du processus de création et se dévoilent de diverses façons dans la conception chorégraphique. Les données de temps sont très importantes dans le processus de composition, d'organisation de structuration de la chorégraphie."
} 
seja, são muito importantes no processo de composição, de organização e de estruturação da coreografia.

Fontaine ainda afirma que:

\begin{abstract}
O parâmetro do tempo intervém nos diferentes campos que a dança reagrupa, o movimento, a frase de movimentos, a composição coreográfica, a ligação com os elementos não coreográficos (música, luz, cenografia, figurino, vídeo, texto), as diversas frases do processo criativo, o desenvolvimento do espetáculo (sua apresentação e sua recepção), a memória. O parâmetro do tempo significa assim uma ligação com a abordagem estética do coreógrafo, com sua cultura e com a corrente a que pertence. O coreógrafo trata a questão do tempo em função da abordagem física do movimento dançado e das problemáticas artísticas que ele implica. ${ }^{27}$ (FONTAINE, 2004, p. 46)
\end{abstract}

O entendimento de temporalidades como trama de nossa corporeidade, em uma dinâmica de metamorfoses incessantes que o espetáculo coreográfico põe em fluxo, se vincula à reflexão proposta pelo professor de estética teatral e coreográfica da Universidade Paris VIII, Michel Bernard (2001). Segundo ele, as temporalidades se processam pelas sensorialidades e fisicalidades de um corpo porque cada percepção é criação de uma temporalidade.

Segundo a pesquisadora em dança Susan Leigh Foster ${ }^{28}$ (2005), a temporalidade é percebida por uma transitoriedade da fisicalidade de um corpo que incorpora e constrói significados. A partir dos estudos culturais, Foster (2005) aborda a fisicalidade como criação de corporalidades que desenvolvem discursos de dança por signos coreográficos, elaborados por um corpo imbuído de ressonâncias sociais e políticas. Uma compreensão de corpo e de temporalidade que está de acordo com o contexto sociocultural.

Um exemplo de que o entendimento de corporalidades é realizado de acordo com seu contexto histórico cultural pode ser observado com o legado da notação de Feuillet, que "localiza o corpo espacialmente em relação aos eixos horizontal e

\footnotetext{
${ }^{27}$ Tradução nossa a partir do original: "Le paramètre du temps intervient dans les différents champs que 'la' danse regroupe, le mouvement, la phrase de mouvements, la composition chorégraphique, le rapport aux éléments non chorégraphiques (musique, lumières, scénographie, costumes et parfois vidéo ou texte), les diverses phases du processus créatif, le déroulement du spectacle (sa présentation et sa réception), la mémoire. Le paramètre du temps est aussi lié à l'approche esthétique du chorégraphe, à sa culture et aux courants auxquels il appartient. Le chorégraphe traite la question du temps en fonction de son approche physique du mouvement dansé et des problématiques artistiques qu'il se donne".

${ }^{28}$ Susan Leigh Foster é coreógrafa, dançarina e professora de história e teoria do corpo no Departamento de Artes da Universidade da Califórnia em Los Angesles (UCLA).
} 
vertical, e temporalmente em relação a uma métrica de progressão através do espaço" ${ }^{29}$. (FOSTER, 2009, p. 107).

O corpo elabora conhecimentos por um processo cognitivo a partir de suas experiências no contexto de existência. Os aspectos temporais em dança implicam uma corporificação cognitiva, ou seja, um "fenômeno-atividade que acontece com o corpo e no corpo, devido a sua interação e acoplamento com o ambiente" (RIBEIRO, 2015, p. 48). A cognição é aqui compreendida como ação de um corpo capaz de aprender e se transformar com essa construção de conhecimento. "A ação corporificada (embodied action) passa a ser chamada de 'enação' e, de acordo com esta perspectiva, não se poderia mais pressupor um observador desencarnado ou um mundo existente apenas na mente de alguém" (GREINER, 2005, p. 35).

A ação corporificada que emerge do conhecimento cognitivo de um sujeito que experimenta relações temporais possibilita a esse corpo a elaboração de suas temporalidades, ou seja, possibilita que ele organize corporalmente e dramaturgicamente os dados espaçotemporais de sua dança segundo seu contexto sociocultural.

As descobertas sensório-motoras de espaço e de tempo viabilizam as temporalidades e espacialidades que um corpo elabora; são temporalidades corporificadas pelas experiências do próprio corpo. O corpo agencia dados espaçotemporais, produzindo temporalidades que serão concretizadas pelo movimento do corpo, que, por sua vez, apresenta as ideias desenvolvidas em uma concepção coreográfica.

O corpo muda de estado cada vez que percebe o mundo. E o corpo artista é aquele em que aquilo que ocorre ocasionalmente como desestabilizador de todos os outros corpos (acionando o sistema límbico) vai perdurar. Não porque ganhará permanência neste estado, o que seria uma impossibilidade, uma vez que sacrificaria a sua própria sobrevivência. Mas o motivo mais importante é que desta experiência, necessariamente arrebatadora, nascem metáforas complexas que serão, por sua vez, operadores de outras experiências sucessivas, prontas a desestabilizar outros contextos (corpos e ambientes) mapeados instantaneamente de modo que o risco tornar-se-á inevitavelmente presente. (GREINER, 2005, p. 123)

\footnotetext{
${ }^{29}$ Tradução nossa a partir do original: "Feuillet notation located the body spatially in relation to horizontal and vertical axes, and temporally in relation to a metricized progression across space" (FOSTER, 2009, p. 107).
} 
O corpo do qual tratamos se constitui por temporalidades. Ele elabora qualidades temporais por seu sistema cognitivo, produzindo redes perceptuais, motoras, de aprendizado e emocionais, de modo coevolutivo com o meio em que vive. Nessa relação entre corpo e ambiente, ambos se coimplicam, não de modo estático ou passivo, mas sim como dependentes no processo de elaboração de informações desse corpo que continuamente e constantemente se vê num fluxo de atualizações.

Segundo o Dicionário de Filosofia (2008), a temporalidade corresponde à espacialidade do corpo: "na medida em que a própria autoconsciência só se dá através da experiência interna do tempo [...] a temporalidade se temporaliza como futuro-que-vai-ao-passado-vindo-ao-presente" (JAPIASSÚ; MARCONDES, 2008, p. $265)^{30}$.

Para a pesquisadora de dança Maxine Sheets-Johnstone ${ }^{31}$ (1966), "de acordo com recentes fenomenologistas, as temporalidades e espacialidades são estruturas inerentes da consciência corporal humana" ${ }^{32}$ (JOHNSTONE, 1966, p. 15). O indivíduo compreende temporalidade pelo seu próprio corpo e as estruturas espaçotemporais estão enraizadas na consciência reflexiva do homem, não como noções abstratas de um tempo e um espaço dados por um conhecimento objetivo, mas sim pela experiência do tempo e do espaço vividos, que nos possibilitam entendimentos espaçotemporais. Essa compreensão espaçotemporal se realiza anteriormente ao conhecimento de tempo por durações mensuráveis.

O indivíduo não tem um passado desde que ele é o seu passado, modo no qual ele não está nele; ele é sempre já um presente. Ele não tem um presente, mas é o seu presente, modo no qual não está fixado no instante: seu presente é sempre um fluido, é um voo que o projeta para seu futuro. Finalmente, ele não tem um futuro, ele é seu

\footnotetext{
${ }^{30}$ Essa citação está abarcada a uma abordagem fenomenológica, primeiramente proposta pelo filósofo alemão Edmund Husserl (1859 - 1938), que trata da experiência do homem em interação com seu ambiente, e engendra um ponto de vista a partir da experiência vivida, da imediata e direta consciência do homem em relação com outro. Essa visão difere da percepção do indivíduo concebido através de fenômenos constituídos por partes separadas. Nessa perspectiva fenomenológica, a construção do tempo descreve uma totalidade das subestruturas passado, presente e futuro, não como formas distintas, mas inter-relacionadas, que não existem como séries isoladas de "agoras", mas derivadas de uma síntese apreendida pelo indivíduo em sua totalidade reflexiva, ou seja, pelas perceppções, subjetividades e consciências, a partir de suas experiências.

${ }_{31}$ Maxine Sheets-Johnstone é coreógrafa norte-americana e professora associada do departamento de filosofia da Universidade de Oregon.

${ }^{32}$ Tradução nossa a partir do original: "According to recent phenomenologists, temporality and spatiality are inherent structures of human consciousness-body". (JOHNSTONE, 1966, p. 15)
} 
futuro no modo de não estar nele, seu futuro ainda não é, mas é delineado sobre o presente do qual ele se move em direção ao futuro como para um objetivo. O indivíduo compreende temporalidade no seu próprio corpo ${ }^{33}$ (JOHNSTONE, 1966, pp. 16-17).

Ou seja, "temporalidade é uma estrutura fundamental da consciência corporal humana" ${ }^{34}$ (JOHNSTONE, 1966, p. 20). A partir da consciência reflexiva das relações com os objetos e com o outro no mundo, um indivíduo se implica em um fluxo de tempo entre futuro, passado e presente, se inter-relacionando nessas estruturas temporais de forma coesa.

\begin{abstract}
A partir desta breve descrição de temporalidade, é evidente que o tempo existe porque existe a consciência humana, e torna-se claro como temporalidade é uma estrutura inerente à consciência humana. A nossa consciência do tempo emana da consciência imediata que temos de nossas próprias totalidades sintetizadas e nunca alcançadas: o meu passado é ontem apenas porque eu sou imediatamente consciente de que meu presente é hoje e meu futuro amanhã. A noite segue o dia como uma sucessão temporal objetiva apenas porque a consciência relaciona aparições regulares de luz e escuridão em um significado temporal que é relacional. Consciência que dota o mundo de uma estrutura temporal unificada pela relação de aparições que são externas também umas às outras. Mas isto constitui este tempo objetivo na base desta própria temporalidade original. ${ }^{35}$ (JOHNSTONE, 1966, p. 21).
\end{abstract}

Essa consciência produzida pela percepção das diferenças, a qual Johnstone aborda, não diz respeito a apreender algo pela reflexão sobre um dado objeto, através do entendimento de suas partes externas, nem como soma e sequência

\footnotetext{
${ }^{33}$ Tradução nossa a partir do original: "Man does not have a past since he is his past in the mode of not being it; he is always already present. He does not have a present, but is his present in the mode of not being fixed in the instant: his present is a flight which projects him into his future. Finally, he does not have a future since he is his future in the mode of not being it, his future is not yet, but is outlined upon the present out of which he moves toward the future as to a goal. Man comprises temporality within himself, for he is such an ekstatic being".

${ }^{34}$ Tradução nossa a partir do original: "In sum, original temporality is a fundamental structure of human consciousness-body".

${ }^{35}$ Tradução nossa a partir do original: "From this brief description of temporality, it is apparent that time exists because human consciousness exists, and it has become clear how temporality is an inherent structure of human consciousness. Our consciousness of time emanates from the immediate awareness we have of our own synthesized yet never achieved totality: my past is yesterday only because I am immediately aware of my presence today and my future tomorrow. Night follows day as an objective temporal succession only because consciousness relates the regular appearances of light and darkness into a meaningful temporal relationship. Consciousness endows the world with a unified temporal structure by relating appearances which are external too one another. But it constitutes this objective time on the basis of its own original temporality".
} 
dessas partes. Trata-se, isto sim, de uma consciência corporal implícita, constituída pela espacialidade que um sujeito apreende com as experiências vividas.

A consciência da experiência do corpo acontece pelas sensações cinestésicas. Essa consciência está diretamente implicada no esquema corporal que possibilita um imediato conhecimento dos sentidos e gestos. Isso significa que, quando falamos de temporalidade, nos referimos a qualidades espaçotemporais singulares: não se trata de todo ou qualquer tempo, mas de estar em um lugar específico e em um momento determinado.

Assim, temporalidades elaboradas por um corpo implicam as suas espacialidades e os compartilhamentos espaciais estabelecidos com o outro. Temporalidades que dizem respeito aos diferentes modos de mover e que se transformam de modo imprevisível. São temporalidades relacionais, seja nos arranjos dos elementos coreográficos na criação de uma composição, seja no fluxo de relações que o corpo a todo momento vivencia no contato com o outro e com os objetos no seu ambiente de existência. Ou seja, temporalidades são geradas devido aos fatores relacionais, trata-se de um fluxo temporal que se processa em razão da habilidade do corpo humano de articular relações.

Segundo a pesquisadora de dança Fabiana Britto ${ }^{36}$ (2008), a questão da temporalidade na dança diz respeito à dinâmica relacional, pois a dança que um corpo cria está baseada em mecanismos de caráter interativo que se propagam ao longo do tempo, gerando a sua organização. Essa é atribuída pela autora não a uma narrativa linear, mas sim a processos simultâneos de relações constituídas por propriedades particulares que formam um conjunto, para ela: "sobretudo o tempo: tudo o que dele deriva está inscrito no fluxo da temporalidade" (2008, p. 41).

Partindo do conceito de tempo assimétrico proposto pelo químico russo llya Prigogine (1917-2003), prêmio Nobel de química em 1977, Britto (2008) afirma que os processos de criação de uma dança registram assimetria entre passado e futuro. A partir da termodinâmica do século XIX, Prigogine produz o entendimento de que os eventos não são uniformes e nem homogêneos, ou seja, não estão em estados de "mais prováveis", pois "vivemos em um mundo improvável, e a flecha do tempo, a possibilidade de definir uma diferença entre o antes e o depois é consequência

\footnotetext{
${ }^{36}$ Fabiana Britto é pesquisadora e professora de dança no Departamento de Dança da Universidade Federal da Bahia.
} 
deste fato"37 (PRIGOGINE; STENGERS, 1991, p. 32). Ele aborda a ideia do devir não como repetição do mesmo por movimentos periódicos, mas sim como um entendimento temporal que está longe do equilíbrio. Para ele, o vir a ser é compreendido pela irreversibilidade e pelas emergências de novos elementos. Segundo a ideia das flutuações criadoras da física quântica (MASSI; PEPE, 2002, p. 404), no vazio quântico ${ }^{38}$, partículas denominadas "buracos negros" teriam desencadeado microscópicas formas de existência por flutuações de explosões entrópicas, e não por processos lineares. Essa ideia nos traz uma dimensão temporal observada por sistemas instáveis no universo, abordada pelo campo do conhecimento da evolução e aprofundada pelo químico nos anos 1980.

Nessa visão, formulada pela segunda lei da termodinâmica, Prigogine instaura um entendimento temporal que sugere imprevisibilidade, indeterminismo, assimetria e irreversibilidade. Essa visão, dependente das condições delimitadas pelo entorno, ajuda a pensar transformações não por processos lineares e constantes, mas sim por dinâmicas específicas.

Baseada nessa noção, Fabiana Britto (2008) afirma que, diferentemente da ideia de causa e efeito, o processo de criação de uma dança não implica a linearidade de acontecimentos previsíveis. Ele ocorre devido ao fluxo de relações interativas, no qual cada sistema sofre mudanças de estado ao longo do tempo. "Sabemos do passado pela sua ressonância na atualidade: a irreversibilidade é uma restrição que impõe o presente como mediador do nosso acesso ao passado" (BRITTO, 2008, p. 85).

Trata-se da rede de relações que possibilitará as temporalidades em dança contemporânea:

O principal fator de caracterização da dança está relacionado com as diversas escalas de tempo que operam simultaneamente no processo de sua feitura - que é, também, o seu modo de relacionarse com o ambiente prévio e ulterior à sua existência. (BRITTO, 2008, p. 26).

\footnotetext{
${ }^{37}$ Tradução nossa a partir do original: 'Vivimos en un mundo 'improbable', y la 'flecha del tiempo', la posibilidad de definir una diferencia entre el antes y el después es simplesmente consecuencia de este hecho".

38 "Entidade que contém potencialmente incontáveis partículas virtuais, uma entidade na qual e a partir da qual as partículas virtuais podem atualizar-se ou aniquilar-se. Não é inerte, mas caracterizada por uma atividade incessante, por uma contínua série de flutuações e pelo surgimento de 'nós' ou 'vórtices' gravitacionais espontâneos". (MASSI; PENNE, 2002, p. 404)
} 
Além de temporalidades apenas serem concretizadas por meio da relação, o fator experiência também é fundamental para as estruturações temporais em dança - aliás, uma dança só existe quando é experienciada. Segundo Johnstone (1966), o conhecimento elaborado com a experiência é percebido antes de qualquer reflexão, julgamento ou interpretação de um aprendizado exterior. Assim, podemos pensar que não há nada de definitivo sobre a dança, essa se constitui como um fenômeno através da experiência vivida, um fenômeno criado para e com a experiência.

Johnstone trata de uma abordagem fenomenológica da dança, na qual os elementos que a compõem não são percebidos e analisados como separados ou como unidades externamente ligadas, mas como um todo, cujos elementos estão relacionados. "Abordar dança como um fenômeno não pressupõe nada de antemão da experiência imediata da dança" ${ }^{39}$ (1966, p. 8). Uma dança torna-se potente quando os dançarinos estão implicitamente conscientes de si mesmos e da forma como se movem, imersos no que estão criando. Isso porque os dançarinos e a dança são apenas um, "criar uma dança é criar uma forma dinâmica singular"40 (JOHNSTONE, 1966, p. 5).

Essas temporalidades elaboradas pelo e no corpo implicam espaços e elaboram percepções, pensamentos e ideias que participam da dança desse corpo: não se trata de um tempo, mas de pluralidades e diversidades de temporalidades envolvidas em fluxos permanentes com o ambiente. Essas temporalidades do corpo se desdobram em outra temporalidade: a do processo de organização de dados espaçotemporais de uma dramaturgia. Buscamos refletir acerca dessa questão nos subcapítulos seguintes, compreendendo que o campo de conhecimento da dança envolve modos próprios de conexões na criação de um processo coreográfico; porém, esse aspecto está diretamente ligado aos modos de produção pelos quais esse corpo se relaciona.

\footnotetext{
${ }^{39}$ Tradução nossa a partir do original: "To approach dance as a phenomenal presence is to presuppose nothing in advance of the immediate experience of dance".

${ }_{40}$ Tradução nossa a partir do original: "To create a dance is to create a uniquely dynamics form".
} 
2.2 Temporalidades e dramaturgia das ações do corpo

Neste momento, abordamos temporalidades como um processo de criação, organização e combinação de procedimentos espaçotemporais que permitem uma dramaturgia. Tratamos de uma noção temporal que qualifica modos de agir viabilizando um pensamento artístico.

De acordo com Fontaine (2017), "a temporalidade é um processo de composição, de organização e de estruturação sobre toda a peça coreográfica. Cada elemento evidentemente também tem sua própria característica temporal" (Informação verbal) $^{41}$. Segundo ela, as temporalidades compõem os modos de estruturação de uma peça coreográfica. Os dados temporais que intervêm em um espetáculo constituem a temporalidade dessa obra - trata-se de elaborações temporais construídas em um processo de criação e que se desdobram em diversos modos e níveis em uma concepção coreográfica.

Compreendemos que a temporalidade se constitui como um processo na medida em que a organização temporal de uma criação cênica acontece por um conjunto circunstancial e ativo de fenômenos ordenados no tempo; o processo diz respeito ao modo de proceder, a sequência ordenada de operações, a um objetivo ${ }^{42}$.

De acordo com Fontaine (2017), "o processo coloca em jogo os dados temporais de uma composição coreográfica da sua construção até sua apresentação. Isso porque o processo corresponde a diferentes fases de um fenômeno"43 (Informação verbal).

As temporalidades constituídas como processo de criação e combinação de questões temporais portam singularidades de uma estruturação cênica porque apresentam uma dimensão temporal pela qual as obras coreográficas são qualificadas através das relações que se estabelecem ao longo do fazer. Os dados

\footnotetext{
${ }^{41}$ FONTAINE, G. Resposta à pergunta de Tatiana Melitello em entrevista realizada em Paris, 2018. Tradução nossa a partir do original: "La temporalité pour moi est un processus de composition, d'organisation et de structuration, sur toute la pièce. Chaque élément a bien sûr aussi son propre caractère temporel".

${ }^{42}$ Segundo a definição de processo pelo Dicionário LE ROBERT, 1994, p. 900.

${ }^{43}$ Aula de Geisha Fontaine no departamento de Artes da Universidade Bordeaux Montaigne. Novembro de 2017. Tradução a partir do original: "Le processus met en jeu les données temporelles d'une composition chorégraphique de sa construction jusqu'à sa présentation. C'est parce que le processus correspond à différentes phases d'un phénomène."
} 
temporais criados intervêm na qualificação de um modo de agir de acordo com uma ideia. Temporalidades que também intervêm na comunicação entre as percepções do dançarino e as do espectador, que não são as mesmas; nas relações estabelecidas com os outros artistas dentro do próprio processo de criação e até mesmo nas escolhas dos parâmetros temporais do movimento selecionados em um trabalho.

Compreendemos que as temporalidades se corporificam como organizações temporais nas especificidades construídas pelas escolhas, seleções e estratégias de dados espaçotemporais que cada artista estabelece para um pensamento coreográfico. Ao combinar temporalidades, o artista constrói e organiza nuances e dinâmicas que permitem a elaboração de um pensamento artístico.

Os procedimentos temporais elaborados em uma dança se atualizam pelo e no corpo, se reconstituindo "na sucessão dos seus instantes, no fluxo de uma temporalidade não controlável que ela tenta portanto imaginar e mesmo visualizar"44 (BERNARD, p. 80, 2001), temporalidades que compõem uma dramaturgia do corpo. Segundo Michel Bernard (2001), essa temporalidade "envolve precisamente a criação de necessidades de uma espécie de tempo ou de um tempo de uma espécie todo distinto e singular"45 (p. 81).

Nesse sentido, as temporalidades não apenas compõem uma dramaturgia, mas se constituem na e pela dramaturgia. Além de uma dança se configurar por uma corporalidade processada através de constantes transformações e mudanças, compondo as dramaturgias do corpo, a dramaturgia pensada como estrutura cênica global é composta por muitos dados temporais, além dos procedimentos temporais do corpo e seu movimento. Uma certa iluminação, uma determinada textura sonora ou mesmo o silêncio, por exemplo, geralmente fazem parte de uma elaboração dramatúrgica, são elementos que participam de uma concepção artística e apresentam procedimentos temporais próprios.

Segundo Fontaine $(2017)^{46}$, a dramaturgia trata da coerência, da organização interna que estrutura uma obra. Ou seja, a maneira de construir no tempo e no

\footnotetext{
${ }^{44}$ Tradução nossa a partir do original: "le corps dansant ne cesse de se dissoudre et de se reconstituer dans la succession de ses instants, dans le flux d'une temporalité non maîtrisable qu'il essaie pourtant d'imager et mieme de visualiser".

${ }^{45}$ Tradução nossa a partir do original: "La danse implique précisément la création du besoin d'une espèce de temps ou d"un temps d'une espèce toute distincte et singulière." (p.81).

${ }^{46}$ Conversas com Dra. Geisha Fontaine em Universidade de Bordeaux Montaigne e no Pôle Enseignement Supérieur Musique / Danse. França. Dia 10 de outubro de 2017: "La dramaturgie traite
} 
espaço, o modo e as ideias de construção de início, desenvolvimento e fim da duração de um espetáculo. Para ela, a estruturação temporal cênica se realiza pelo processo que opera desde o início da concepção da coreografia até sua apresentação.

O termo dramaturgia não é muito utilizado por Fontaine (2018), mas as suas proposições ajudam a pensar em torno desse termo. Segundo ela, a dramaturgia varia segundo os contextos culturais e históricos. Frequente na Alemanha em Países do Norte, por exemplo, a dramaturgia apresenta uma função bem clara e específica que depende do trabalho do dramaturgista. $O$ dramaturgista traz elementos da pesquisa, da documentação e contribui para a coerência e para a estruturação de uma obra ${ }^{47}$ (Informação verbal): "historicamente a dramaturgia é ação do dramaturgista que contribui na definição do fio condutor da criação" 48 (FONTAINE, 2017). Segundo ela, o termo dramaturgia não é muito utilizado no campo da dança na França - os franceses preferem utilizar as expressões composição ou escritura coreográfica.

Mesmo compreendendo que a dramaturgia se refere também ao ofício do dramaturgista de colaborar com referências que dizem respeito a toda uma concepção artística, a presente pesquisa busca focalizar as próprias ações do corpo. Centramo-nos na observação de temporalidades a partir das ações do corpo e seu movimento, pois entendemos que é por meio disso que as coerências de um trabalho cênico serão construídas para a composição de todos os procedimentos temporais elaborados nessa composição. Mesmo compreendendo que a dramaturgia abrange diversos elementos de uma construção cênica, nossa perspectiva se centraliza no fato de que é a partir das ações corporais que uma concepção cênica é elaborada, porque a ação diz respeito aos processos sensoriais, motores e cognitivos. Ou seja: ela é pensamento.

de la cohérence de l'organisation interne qui structure une oeuvre. C'est-à-dire la manière de construire dans le temps et l'espace, la manière et les idées de construction de début, de développement et du fin d'un spectacle, son organisation de la timeline d'un spectacle. Pour elle, la structuration temporelle scénique se fait par le processus qui s'opère dès le début de la conception de la chorégraphie jusqu'à sa présentation."

${ }^{47}$ Conversas com a Dra. Geisha Fontaine em Paris, 2018: "La dramaturgie varie selon les contextes culturels et historiques. La dramaturgie, très courante en Allemagne et Pays du Nord, par exemple, présente une fonction très claire et spécifique qui dépend du travail du dramaturge. Le dramaturge apporte des éléments de recherche, de la documentation et participe à la cohérence et à la structuration d'une oeuvre".

48 "Historiquement la dramaturgie, c'est l'action du dramaturge. Les dramaturges contribuent à définir le fil conducteur de la création." 
Lembramos que a etimologia da palavra dramaturgia provém do grego e denota ação. Entendemos que as ações do corpo disparam a conexão entre os elementos cênicos; evidentemente, cada um dos elementos constitutivos de uma dramaturgia, como a iluminação, as texturas sonoras, o silêncio, por exemplo, apresentam características temporais próprias que viabilizam as coerências de uma obra. Contudo, buscamos observar a perspectiva de temporalidades sob o viés do corpo e de seu movimento, observando como elas articulam as coerências elaboradas em uma dança.

De acordo com a dramaturgista Rosa Hercoles ${ }^{49}$, a dramaturgia é compreendida a partir das ações do corpo, portanto, a denominação mais precisa nesse caso seria dramaturgia do corpo que dança (2010). Essa dramaturgia tece coerências pelo e no próprio corpo. Por exemplo, o fato de um artista escolher realizar toda uma criação em velocidade lenta implica um conjunto de entendimentos que difere de uma outra criação, na qual o dançarino escolhesse utilizar somente a velocidade acelerada para os seus movimentos, por exemplo. "Cada escolha provoca uma determinada ação no mundo" (BASTOS, 2003, p. 63). As ações corporais apresentam seleções, elaborações e posições de um pensamento artístico configuradas pelo próprio movimento do corpo.

A dramaturgia implica uma estrutura coerente organizada pelas ações corporais e, como o "corpo é pensamento" (KATZ, 2010), a lógica que parte dessas ações é aquilo que estabelece diálogo com todos os materiais concebidos em um trabalho cênico. Isso envolve uma elaboração de coerências e lógicas na articulação de um discurso coreográfico.

A construção desses sentidos se realiza pelas temporalidades na medida em que a cumplicidade das relações vai se compondo no processo de construção. "O discurso da cumplicidade passa, sobretudo, por unificar, numa rede de dobras, os elementos cênicos através da temporalidade em que as relações de sentido se estabelecem e do espaço em que decorrem" (PAIS, 2012, p.103).

Segundo a autora Ana Pais (2016), a dramaturgia trata da coerência de todos os materiais cênicos organizados na estrutura de um espetáculo. A dramaturgia é compreendida como "modo de estruturação e relações de sentido no espetáculo" ( $p$.

\footnotetext{
${ }^{49}$ Rosa Hercoles é pesquisadora de dança e professora do Departamento de Artes do Corpo da PUC/SP.
} 
25), que operam desde a prática do processo de criação do espetáculo à efemeridade de sua apresentação.

Ao escolher ou fazer opções relativamente aos materiais cênicos e à sua articulação na cena, o olhar artístico estrutura-os dramaturgicamente, fundamentando essas opções e criando uma lógica e uma coerência próprias a cada espetáculo. (PAIS, 2012, p. 43)

As temporalidades acontecem por uma tessitura de relações entre os materiais espaçotemporais ordenados num processo de criação. São temporalidades que não se esgotam na estreia de um espetáculo - pelo contrário, trata-se de um processo que se potencializa na tomada de consciência da relação entre o modo como se dá um espetáculo e os efeitos perante o público.

A dramaturgia envolve o laço de cumplicidade entre a cena e o espectador na duração de um espetáculo. Isso implica refletir quais procedimentos temporais são elaborados pelo coreógrafo e/ou por coletivos, como essas temporalidades são organizadas no compartilhamento com o público, de que modo as escolhas temporais estão entrelaçadas no pensamento que esse artista intenta comunicar ao espectador, como ele desenvolve seu material coreográfico no perpassar temporal compartilhado com o público.

As temporalidades estão, assim, diretamente vinculadas à dramaturgia em dança. Se as ações do corpo "estimulam conexões entre as estruturas de atividades corporais e operações cognitivas" (BASTOS, 2003, p. 15), elas também estão relacionadas à coreografia. Nesse sentido, abordamos a seguir como a dramaturgia em dança é percebida em relação à coreografia, com o intuito de aprofundar a forma como as temporalidades intervêm nessa relação. 
2.3 Temporalidades implicadas na dramaturgia de dança e na coreografia

Os procedimentos espaçotemporais correspondem aos modos como cada coreógrafo os articula em uma dança. São temporalidades criadas que compõem uma dramaturgia do corpo em dança, mas que também se concretizam como materiais da coreografia.

Etimologicamente, a palavra coreografia associa a forma grega koreos (dança) à grafia (escrita), ou seja: escrita dos movimentos dos corpos. Já a palavra dramaturgia, como mencionamos, provém do grego drao, que significa agir.

O significado de dramaturgia que faz referência à ação está intimamente ligado à coreografia: "no caso da dança, essa ação remete diretamente aos passos e aos gestos e ao modo como eles são mostrados" (KATZ, 2010, pp.163-167). Ação essa que se constrói no tempo real da criação do movimento do corpo.

A dramaturgia em dança se compõe pelas ações do corpo e está relacionada à composição coreográfica. Diferentemente de um simples agrupamento de elementos, a dramaturgia estabelece a organização da cena pelas conexões de suas propriedades constitutivas. De acordo com Hercoles $(2005,2010)$, a dramaturgia do corpo em dança implica a estruturação de suas ações, de modo que a construção singular de uma dança depende de como o corpo ordena os elementos que compõem o movimento. A organização dessa dança vai se dar de acordo com as questões que ela pretende discutir pela elaboração das ações corporais.

Nesse sentido, as questões temporais organizadas pelas ações do corpo apresentam escolhas temporais que determinam toda uma estrutura cênica. São temporalidades que permitem uma configuração da cena e uma composição de ações corporais.

Segundo o crítico de dança Jean Marc Adolphe (1997), "a coreografia é intrinsecamente a dramaturgia de dança [...] Ela tenta captar os fluxos de circulação de sentidos. A dramaturgia é um exercício de circulação"50 (pp. 32-33). De acordo com ele, a dramaturgia do movimento consiste no estudo da própria lógica construída pelos agenciamentos corporais, perceptivos, temporais e espaciais

\footnotetext{
${ }^{50}$ Tradução a partir do original : "La 'chorégraphie' est intrinsèquement la dramaturgie de la danse [...] Elle tente de capter les flux de circulation du sens. La dramaturgie est un exercice de circulation."
} 
promovidos pelo corpo dançante. Esse, por sua vez, coloca em fluxo de circulação todos os materiais que se conectam nesse processo. Em vez de serem organizados separadamente em "caixas", eles estão comprometidos com o "humano e sua responsabilidade de ação e não submetidos por um fator religioso ou divino" (ADOLPHE, 1997, p. 32). De acordo com o autor, diferentemente de abordar a dramaturgia como um sentido dado, ela interroga a ação que se apresenta na articulação de sentidos em cada processo.

A relação íntima entre dramaturgia e coreografia não é nova. Segundo Hercoles (2005), a dramaturgia em relação à ação e ao movimento das cenas foi proposta em 1760 na publicação Lettres sur la danse, pelo mestre de balé francês Jean Georges Noverre (1727-1809). A obra de Noverre exprime o conjunto de concepções teóricas e críticas da dança vigente em seu tempo, apresentando características dramáticas a partir do que chamou de "balé de ação".

Naquele momento, o balé de ação "utiliza-se da expressão gestual, incorpora a pantomima e com isso torna-se capaz de criar a ilusão" (MONTEIRO,1998, p. 34). Contudo, as características que apreendem a pantomima com vistas à verossimilhança e à imitação da natureza humana já existiam nos balés de corte criados nos bailes do Renascimento italiano e francês: "o balé de corte reunia dança, recitativos e cantos em um enredo dramático e usando alegorias" (KATZ, p. 165).

Noverre, ao longo da carta 13, expõe que a "coreografia [...] é a arte de escrever a dança com a ajuda de diferentes signos" (MONTEIRO, 1998, p. 339). Essa afirmação toma como referências o tratado de Orchéosographie, publicado em 1588 por Thoinot Arbeau, e os princípios da notação, publicados em 1700 com a obra Chorégraphie ou l'art de décrire la danse par caractère, figures et Signes démonstratifs, de Raoul Anger Feuillet.

Segundo Noverre:

Os passos a serem seguidos eram indicados sobre esses percursos com traços e signos demonstrativos e convencionais; a cadência ou os passos eram assinalados por pequenas barras colocadas transversalmente, dividindo os passos e fixando o tempo; a música sobre a qual esses passos foram compostos aparecia no alto da página, de forma que oito compassos de coreografia equivaliam a oito compassos da música; por meio desse arranjo era possível soletrar a dança, contanto que se tivesse a precaução de nunca trocar a posição do livro, mantendo-o sempre na mesma direção. Eis, Senhor, o que foi outrora a coreografia. A dança era simples e pouco composta, a maneira de escrevê-la era consequentemente simples e 
essa leitura facilmente podia ser aprendida sem grandes problemas. Hoje, no entanto, os passos são complicados, são duplos, triplos, há uma imensa variedade de combinações entre eles; é pois muito difícil colocá-los por escrito e ainda mais difícil decifrá-los. (MONTEIRO, 1998, p. 340).

Podemos observar que o entendimento de dramaturgia como ação e movimento das cenas, proposto por Noverre, surge da relação com a coreografia, a partir das obras Orchéosographie, publicada em 1588 por Thoinot Arbeau, e Chorégraphie ou l'art de décrire la danse par caractere, figures et Signes démonstratifs, publicada em 1700 por Raoul Anger Feuillet.

Mas além disso, esses escritos ajudam a observar uma determinada configuração temporal implicada no surgimento da noção de coreografia. A notação musical, com a qual os balés de ópera deveriam oferecer uma cena que encadeasse e que ligasse intimamente o primeiro ato ao segundo, o segundo ao terceiro e assim por diante, trazia as "sequências necessárias ao andamento do drama", andamento esse determinado por uma partitura musical: "a música, então, traria consigo o caráter do poema, traçaria as ideias do poeta" (MONTEIRO, 1998, p. 252).

A partir dessa ideia de tempo linear, contínuo e determinado, da coreografia vinculada à música exposta pelos princípios da notação gráfica, abordada nos séculos XVIII e XIX, podemos observar a variedade de desdobramentos que isso gerou nos dias de hoje, na co-existência entre dança e música.

Apesar de a música em geral lidar com um tempo sequencial e contínuo, esses mesmos elementos temporais se desorganizam e se transformam através de novas articulações no século XX e XXI, subvertendo os entendimentos de tempos outrora promovidos. Atualmente, a dança não utiliza apenas esse tempo, mas sim uma pluralidade de estratégias temporais de criação.

No início do século $X X$, vários coreógrafos utilizam uma abordagem na qual música e dança se apresentam como linguagens independentes, como Merce Cunningham, Rudolf Laban ${ }^{51}$ e Martha Graham ${ }^{52}$. De lá para cá, as variações dessa

\footnotetext{
${ }^{51}$ Rudolf Laban (1879 - 1958) coreógrafo e artista visual, que teve um papel fundamental em dança, desenvolvendo o seu sistema de linguagem do movimento, Laban Movement Analysis (LMA) ou Sistema Laban. Abordamos mais Laban no capítulo "Parâmetros temporais do movimento", no presente texto.

${ }^{52}$ Martha Graham (1894 - 1991) é uma bailarina, coreógrafa e professora estadunidense que revolucionou a dança moderna no século XX. "Os primeiros pioneiros da dança moderna de Duncan a Graham rejeitaram o que eles acreditavam ser 'artificial' (e ortopedicamente não saudável) do vocabulário do balé em favor de movimentos mais próximos ao 'natural' do corpo". Tradução nossa a
} 
relação são trabalhadas de diversas formas: por exemplo, a música na função de criar uma atmosfera, na ligação entre cenas, a presença de músicos em cena, a música em diálogo com a improvisação etc. Trata-se de temporalidades que colocam em jogo uma pluralidade de diálogos explorada na relação entre música e dança.

Vale lembrar que mesmo uma composição que utilize uma notação coreográfica $^{53}$, que subsiste independentemente à existência dos corpos, a notação se distingue da dança propriamente dita realizada no tempo presente de sua apresentação. Ou seja, ela se distingue dos corpos que dançam essa notação, pois há uma adequação entre a coreografia e o modo como cada intérprete lerá essa notação. A "leitura" ou interpretação de cada artista, bem como o modo de construção de uma dança, fazem parte da dramaturgia.

Segundo Hercoles (2005), as novas ideias surgidas em dança tanto no século XVIII, com a proposição de Noverre (como o abandono do ornamento excessivo), quanto no século XIX, com o coreógrafo russo Michel Fokine (1880-1942), que libera a dança como legenda e propõe uma ideia de unidade de concepção interpretativa, geraram ecos no entendimento de dramaturgia como ação. Ademais, essas ideias "pavimentam o caminho para que, hoje, a noção de espetáculo como produto final seja substituída pela ideia de um produto cênico que represente uma solução possível, em constante processo de transformação" (HERCOLES, 2005, p. 20).

A dramaturgia de dança pode ser então compreendida pela construção de coerências trabalhadas no desenvolvimento de uma coreografia, desde o seu início até o seu término. Entendemos também que a construção dessas coerências é realizada pelo próprio movimento dançado, "fazendo do movimento de dança um fiador de uma dramaturgia de dança" (KATZ, 2010, p. 163). Trata-se de perceber o

partir do original: "The early pioneers of modern dance - from Duncan through Graham - rejected what they believed to be the "artificial' (and orthopedically unhealthy) vocabular of ballet in favor of movements more in keeping with the 'natural' inclinations of the body." (COPELAND, 2004, p. 64). "Graham e Skolow derivaram seus movimentos estéticos dos ritmos da respiração". Tradução nossa a partir do original: "Graham and Sokolow both derived their movement aesthetic from the basic rhthms of breathing" (COPELAND, 2004, p. 54).

${ }^{53}$ Embora os sistemas de notação tenham um papel diferente da partitura musical, a arte da notação ou a transcrição escrita do movimento dançado desempenha atualmente uma função especializada, "a maioria dos dançarinos não podem ler a notação coreográfica. O que acaba por desempenhar um papel de arquivo reservado aos especialistas" (FONTAINE, 2004, p. 22), embora ela seja um modo de durabilidade uma obra de dança. Tradução nossa a partir do original: "Actuellement, la majorité des danseurs ne peuvent pas lire la notation choregraphique, qui joue essentiellement un rôle d'archive réservée aux spécialistes". 
corpo como elemento articulador das estruturações e coerências que tecem uma dramaturgia do corpo que dança.

Isso nos permite observar que as temporalidades construídas pelas ações corporais em uma dramaturgia se estabelecem em diálogo com os procedimentos temporais criados pelos movimentos. Ou seja, são temporalidades elaboradas pelo conjunto de questionamentos dos modos temporais trabalhados.

As escolhas das qualidades temporais e espaciais durante o processo de ensaios com a elaboração das ações e dos movimentos dançados vão conduzindo e sugerindo novas temporalidades. A partir dessas, outras qualidades temporais são desdobradas no desenvolvimento da concepção cênica.

Em vez de as ações serem organizadas em uma ordem sequencial linear, como foram abordadas outrora no vínculo com a música, o processo de organização e combinação das ações na estrutura dramatúrgica de um espetáculo se expande, no que tange aos modos de organização temporal, do século XX para os dias de hoje. As disposições dessas ações têm sido exploradas em diversos sentidos e direções na composição de uma estrutura cênica.

A lógica interna construída pelo desenvolvimento do movimento e do pensamento que possibilita a estrutura de um trabalho artístico implica uma temporalidade que não é definida de antemão, e sim atualizada a cada elemento descoberto no decorrer de sua feitura. Isso indica um fator temporal de atualizações e transformações na dramaturgia em dança. A diversidade das criações e escolhas temporais e a pluralidade dos modos como elas são dispostas e organizadas em um processo de criação trazem uma expansão de possibilidades de agenciamentos dessas temporalidades.

$\mathrm{Na}$ construção de uma dramaturgia de dança, diversas informações são selecionadas e entremeadas não por uma ordem cronológica ou linear, mas labiríntica, de acordo com as temporalidades - ou seja, pela lógica criada no interior desse processo.

Diferentemente de uma teoria, aplicação de regras ou modelos, o trabalho dramatúrgico consiste na busca pela estrutura de todo o material que se desenvolve no processo de um trabalho artístico. O trabalho dramatúrgico trata de "investigar uma via pela qual se organiza e estrutura todo o material que chega sobre a 
mesa"54. A "dramaturgia, como é chamada recentemente, é entendida como a base de toda criação artística, que se agita na montagem de uma peça"55 (KERKHOVE, 1997, p. 19). Trata-se dos elementos que, em lugar de serem sobrepostos, vão se constituindo como uma rede, e isso se compõe pelas informações que ainda estão por vir.

Nesse sentido, "torna-se imperativo o reconhecimento dos distintos modos como as instruções que constituem o movimento são singularmente implementadas por cada corpo" (HERCOLES, 2010, p. 199). Para Hercoles, a dramaturgia

\begin{abstract}
Em seu sentido mais geral trata da instância que se ocupa com a identificação, a proposição e o estabelecimento dos critérios que irão orientar a construção de uma obra dramática. Atualmente, tais critérios não se encontram determinados a priori, mas sim, surgem do conjunto de opções estéticas e conceituais que todos os profissionais envolvidos numa composição, coreográfica ou teatral, realizam ao longo do processo criativo. Ou seja, a dramaturgia de agora não cabe em definições por escola, estilo, etc, uma vez que se constrói no tempo real da criação (HERCOLES, 2005, p. 10).
\end{abstract}

Trata-se de uma ideia de dramaturgia do corpo que consiste na continuidade de uma temporalidade através da qual os elementos vão se interconectando, de acordo com uma lógica temporal construída na criação. O processo se opera segundo as possíveis ações corporais propostas pelo movimento para exprimir uma determinada ideia.

As temporalidades que implicam as escolhas temporais elaboradas por um processo de criação em dança, e que operam de acordo com sua proposta coreográfica, permitem uma dramaturgia na medida em que elas se constroem pelo e no corpo, por um modo de pensamento que orienta toda uma obra coreográfica. As temporalidades, aqui pensadas como procedimentos espaçotemporais, orientam toda uma obra porque viabilizam tanto uma dramaturgia em dança quanto uma coreografia.

Trata-se de temporalidades que vão se construindo e se concretizando, tornando-se visíveis pouco a pouco na configuração de um trabalho cênico. Nesse processo, assumem-se dobras e múltiplas direções de estruturações de sentidos e

\footnotetext{
${ }^{54}$ Tradução nossa a partir do original: "c'est chercher une route par laquelle on arrive a 'ranger' et structurer tout le matériel qui arrive 'sur la table' en travaillant à une production".

${ }^{55}$ Tradução nossa a partir do original: "La 'dramaturgie' comme on l'appelle depuis peu de temps, est bien entendu à la base de toute création artistique, qu'il s'agisse de monter une pièce".
} 
de coerências de um espetáculo. São temporalidades que se tornam concretas na dramaturgia do corpo que dança pelo modo como as organizações espaçotemporais são agenciadas por um artista na construção de um pensamento coreográfico.

As "temporalidades provisórias" constituem o corpo e o movimento, como afirma Fontaine (2004), e acontecem de modo "relacional", segundo Britto (2008), modo no qual os elementos coreográficos são articulados de maneira imprevisível. Constantemente, surgem novas questões e desdobramentos em todas as etapas de construção de uma dança. Assim, a noção de dramaturgia como processual está diretamente ligada a fatores temporais, ou seja, temporalidades se vinculam diretamente a essa dramaturgia.

As temporalidades compõem uma dramaturgia de dança por seu caráter relacional e processual. Elas estão presentes na organização das ações corporais que constantemente mudam, no conjunto de procedimentos espaçotemporais que se transforma a cada elemento que se estabelece na criação, no tempo de pesquisa e nas qualidades construídas nesse processo.

Ou seja, a escolha do modo e da disposição dos dados temporais elaborados em um processo participam de uma dramaturgia do corpo em dança, na medida em que essas informações se realizam de modo específico, de acordo com as espacialidades e qualidades temporais articuladas. Elas também se realizam com os questionamentos desenvolvidos de forma coesa no decorrer desse processo, num jogo dinâmico de atualizações e modulações temporais criadas para um trabalho cênico.

A dramaturgia do corpo em dança é tecida pelos modos de ação corporal imbuídos de espacialidades e qualidades temporais. Essa dramaturgia não acontece por uma composição na qual tais ações se dispõem de modo pré-determinado ou fixo. A disposição e estruturação temporal das informações se realizam de modo específico, de acordo com as seleções temporais de cada processo. A característica processual dessa dramaturgia acontece porque há nela um jogo dinâmico de atualizações e modulações temporais criadas em cada processo. A questão temporal é, portanto, vital na dramaturgia. 
2.4 Dramaturgia que transborda os marcos de um texto dramático

Embora o termo dramaturgia esteja historicamente atrelado ao teatro, a dramaturgia de dança não é a mesma do teatro: há diferenças de materiais que englobam o percurso histórico de cada uma dessas áreas do conhecimento. De acordo com a dramaturgista de teatro e de dança Marianne Van Kerkhonve ${ }^{56}$, "podemos nos ocupar de dramaturgia durante anos e não sermos capazes de dar uma definição clara para exprimir o que esse termo representa exatamente" ${ }^{57}$ (KERKHONVE, 1997, p. 19). No entanto, ela afirma que há semelhanças entre essas duas disciplinas das artes cênicas. Isso porque a

dramaturgia está sempre vinculada às estruturas [...] ela trata de trabalhar com a tensão entre as partes e o todo, de desenvolver a relação entre os atores/dançarinos, entre os volumes, as disposições no espaço, os ritmos, as escolhas dos momentos, os métodos etc. Ela trata da composição. ${ }^{58}(1997$, p. 21$)$

Se, historicamente, a dramaturgia implica o ofício do dramaturgista, frequentemente esse ofício em dança é assumido pelos próprios coreógrafos na elaboração de um pensamento cênico (ADOLPHE, 1997, p. 33), promovido, nos dias de hoje, cada vez mais pelo corpo e seu movimento. A partir das ações corporais, são configurados alguns elementos tais como luz, som, manipulação de objetos, por vezes palavras, textos e projeções, com o objetivo de uma organização e uma estruturação coerentes nessa dramaturgia.

Mas além dos próprios coreógrafos, os dançarinos e a equipe de um processo criativo podem realizar o ofício do dramaturgista. Segundo o dramaturgo Guy Cools (2005), enquanto, no século XIX, o teatro foi regido por atores e, no

\footnotetext{
${ }^{56}$ Marianne Van Kerkhonve é dramaturgista, colaboradora nessa qualidade nas produções da coreógrafa Anne Teresa De Keersmaeker entre 1985 e 1990.

${ }^{57}$ Tradução nossa a partir do original: "On peut s'occuper de dramaturgie depuis des années et n'être toujours pas capables d'en donner une définition claire, d'exprimer ce que cela répresente exactement".

${ }^{58}$ Tradução nossa a partir do original: "La dramaturgie a toujours quelque chose a voir avec des structures: il s'agit de "contrôler" le tout, de "peser" l'importance des parties, de travailler avec la tension entre les parties et le tout, de développer la relation entre les acteurs/danseurs, entre les volumes, les dispositions dans l'espace, les rythmes, les choix des moments, les méthodes etc; bref, il s'agit de composition."
} 
século $X X$, por diretores consagrados, no século $X X I$, testemunhamos uma era de processos coletivos guiados - mais que dirigidos - por dramaturgos ${ }^{59}$. Contudo, o processo, que é segundo ele sempre coletivo, traz atualmente para o campo da dança o papel do dramaturgo em diálogo com o coreógrafo e com os dançarinos, de modo a explorar as ações concretas no corpo de tais dançarinos.

A partir século $X X$, o coreógrafo estreita a relação de trabalho com 0 dramaturgista, como é o exemplo de Marianne Van Kerkhonve com a coreógrafa Anne Teresa de Keersmaeker, do alemão Raimund Hogue com a coreógrafa Pina Bausch, do francês Claude-Henri Buffard com o coreógrafo Jean-Claude Gallotta, do holândes Robert Steijn com o performer Frans Poelstra.

o dramaturgista contribui com as referências e colabora para a estruturação de um pensamento artístico. A dramaturgia engloba a reflexão sobre os vários elementos da coerência de um pensamento e sobre o papel dos objetos, dos acessórios, por vezes imagens e textos, elementos que participam das conexões para estabelecer as lógicas de uma concepção artística global. O dramaturgista de dança estabelece o diálogo com o coreógrafo colaborando com ele, clarificando e questionando suas escolhas, suas ideias intelectuais, suas intenções. Ele é "o primeiro espectador" da obra no processo de sua feitura. (FONTAINE, 2017)

Todas as ideias sobre processo e composição no ambiente de dança que surgem no século $X X$ atualizam a noção de dramaturgia. Porém, persistem ainda diversos entendimentos do termo, tanto no teatro quanto na dança, que atravessam a história dessas linguagens. Não pretendemos aqui esmiuçar a historiografia da dramaturgia, mas sim abordar alguns entendimentos acerca desse conceito para compreender como a temporalidade implica modos pelos quais as relações e coerências se estabelecem em dramaturgias contemporâneas de dança.

\footnotetext{
${ }^{59}$ Disponível em: https://www.erudit.org/fr/revues/jeu/2005-n116-jeu1111093/24810ac/ Acesso em: 24.ago.2018.

${ }^{60}$ Entrevista à Tatiana Melitello. "Le dramaturge contribue aux références et collabore à la structuration d'une pensée artistique. La dramaturgie englobe la réflexion sur plusieurs éléments dans la cohérence d'une pensée et sur le rôle des objets, des accessoires, parfois des images et des textes, éléments qui participent des connexions à établir et des logiques d'une conception artistique globale. Le dramaturge de danse établit un dialogue avec le chorégraphe en collaborant avec lui, clarifie et questionne ses choix, ses idées intellectuelles, ses intentions. II est "le premier spectateur » de l'oeuvre en train de se faire".
} 
Enquanto, na dança, a dramaturgia foi designada no século XVIII ${ }^{61}$ como "ação dramática coerente" (HERCOLES, 2005, p.11) com a proposição de Noverre e o dramaturgo Gotthold Lessing (1729-1781), a dramaturgia teatral foi designada no mesmo período como a ação da obra teatral para qualificar tanto o gênero do drama burguês (que foi situado entre a comédia e a tragédia, e seguia regras de determinismo, causalidade, ilusionismo e conflito), quanto o gênero romântico e lírico no século XIX.

No contexto do século XVIII, enquanto a dramaturgia de dança estabelecia relações com a música, mais precisamente com a ópera francesa, a qual usava a palavra recitada, no teatro, as relações eram traçadas por uma estrutura narrativa de um texto. Segundo Pavis (1998), a dramaturgia teatral clássica lida com o trabalho do autor de uma obra, buscando elementos da construção dramática constitutivos do texto clássico, como, por exemplo, o início, o conflito, o final e o epílogo. Para Pavis:

\begin{abstract}
A dramaturgia, em seu sentido mais geral, é a técnica (ou a poética) da arte dramática que busca estabelecer os princípios de construção da obra, a partir de exemplos concretos, ou a partir de um sistema de princípios abstratos. Esta noção pressupõe um conjunto de regras especificamente teatrais cujo conhecimento é indispensável para escrever uma obra e analisá-la corretamente. (PAVIS, 1998, p. 148)
\end{abstract}

Esse sentido clássico de dramaturgia teatral, ligado à narrativa de uma obra literária pelo poeta/autor, traz para a ação dramática a lógica do tempo dos acontecimentos contínuos e sucessivos, "pois a ação deve ser completa, tendo começo, meio e fim" (PALLOTINI, 1988, p. 6), como apresentado pelo tratado de Aristóteles na Poética.

Essa unidade de tempo abordada na Poética possibilita a continuidade e a verossimilhança no rigor da dramática, que atinge o seu ápice no ideal do Renascimento, com o reforço do palco de manter a ilusão cênica. Esse palco se distinguia do teatro grego, aberto e com iluminação natural, que, por sua vez, se

\footnotetext{
${ }^{61} \mathrm{O}$ termo dramaturgia, "no século XVIII, passou a ser utilizado com um segundo significado, suplementar ao sentido aristotélico de composição dramática: o de crítica, ou melhor, o de consciência crítica. Este advém da chamada tradição alemã da dramaturgia e do aparecimento da figura do dramaturgista, ambos protagonizados por G.E. Lessing [...]. Escrita dramática ou composição dramática implicam, naturalmente, um autor e um conjunto de regras" (PAIS, 2016, p. 31) nos quais uma obra deve ser escrita.
} 
diferenciava da atitude dramática no teatro medieval, onde "o tempo é, praticamente, todo o tempo, os estilos se misturam, os personagens se multiplicam [...] com cenários simultâneos e atores à vista" (PALLOTINI, 1988, pp. 55-56).

De todo modo, a dramaturgia, baseada na narrativa de formas literárias por meio de histórias, referindo-se frequentemente aos mitos e a situações primitivas, no século XVIII e XIX, é transformada no século XX. Nesse período, a dramaturgia teatral se atualiza da "arte da composição de obras de teatro"62 para abarcar o caráter autobiográfico, não-representacional e não-narrativo.

Um dos autores renovadores nas artes cênicas, no que tange às experimentações que desmontaram o aparato realista-naturalista do século XVIII, foi o alemão Bertolt Brecht (1898-1956). Ele trabalhou com a dialética, conceitos marxistas e trouxe para a prática da narração a sobreposição de perspectivas, a fragmentação de textos, o desenvolvimento frequentemente modificado e não direcionado ao desfecho. "Ele trouxe uma nova acepção de dramaturgia - a adaptação. Adaptar é manusear um texto como matéria, como ponto de partida para uma alteração profunda na forma, acrescentando-lhe uma leitura própria, um outro ponto de vista" (PAIS, 2016, p. 45).

Essas abordagens permitem observarmos que, em seu sentido mais recente, a dramaturgia transborda os marcos de um texto dramático para englobar realizações cênicas singulares, tendo o corpo como modificador de ritmos, abordagens, qualidades de movimento construídas pelas escolhas específicas que implicam uma visão de mundo.

No ambiente contemporâneo da dança, diferentemente de lidar com a preservação da voz do autor, a dramaturgia explora questionamentos, que, por sua vez, portam singularidades, projetam pontos de vista relacionados ao momento presente de um contexto social e político, conhecimentos e ideias elaboradas pelo corpo acerca do ambiente no qual ele se relaciona. Isso implica lógicas heterogêneas e diferentes percepções, cada vez mais exploradas e estruturadas artisticamente por processos coletivos e relacionais.

Os processos artísticos relacionais têm sido compostos por pessoas de diferentes formações artísticas que buscam se organizar para propor ações artísticas conjuntamente, na elaboração de procedimentos espaçotemporais na

\footnotetext{
${ }^{62}$ Tradução nossa a partir do original: "Según el dicionário francês Littrê, la dramaturgia es el 'arte de la composición de obras de teatro'." (p. 147).
} 
feitura de um trabalho de dança. Nos dias de hoje, há uma notável expansão de propostas artísticas realizadas por coletivos e lógicas heterogêneas que os regem, advindas de campos diversos do conhecimento. Isso contribui para os graus de complexidade e de contaminação de temporalidades por diferentes procedimentos espaçotemporais. Além disso, observamos uma expansão de temporalidades ao testemunharmos um aumento de sobreposições entre outras linguagens artísticas, como, por exemplo, o uso da palavra, do texto, de artes visuais, de elementos do circo, de performances musicais, de vídeo-projeções e novos recursos tecnológicos entremeados a um espetáculo de dança.

Percebemos primeiramente que a expansão de temporalidades acontece nos entrecruzamentos de procedimentos espaçotemporais construídos ao longo de um processo de criação em dança. Mas, além disso, a complexidade de temporalidades parece ganhar novos contornos com a hibridização das linguagens artísticas, que ultrapassam os limites entre os diferentes formatos de apresentação, como, por exemplo, espetáculo, performance, instalação, dança, teatro e conferência.

O que queremos dizer é que os procedimentos temporais de cada um desses formatos cada vez mais se misturam e se entrelaçam em uma apresentação, a qual, para alguns, pode ser de dança, para outros, de performance ou teatro. Percebemos, assim, que a dança vem explorando diferentes temporalidades e diferentes procedimentos espaçotemporais em um processo de criação.

Por outro viés, "mesmo se uma dança utiliza um texto, por exemplo, a utilização desse texto não será a mesma que é feita no teatro", como afirma Fontaine (Informação verbal) ${ }^{63}$. Existem agenciamentos específicos em dança, mesmo no tratamento de materiais advindos de outras linguagens artísticas.

A relação com elementos de outras linguagens artísticas é trabalhada e apresentada por uma elaboração de sentidos próprios de acordo com o campo de cada linguagem. O texto, no teatro, é trabalhado de maneira muito diferente do que na dança, por exemplo. Mesmo que haja a palavra ou o recurso do texto em dança, trata-se de materiais que não serão utilizados da mesma maneira como no sentido do teatro.

\footnotetext{
${ }^{63}$ Resposta à entrevista à Tatiana Melitello. Tradução a partir do original: "Même si une danse utilise un texte, par exemple, l'utilisation de ce texte ne sera pas la même que celle qui en est faite au théâtre. Même quand des mots sont énoncés, c'est dans d'autres enjeux qu'au théâtre".
} 
É preciso lembrar também que a contaminação de temporalidades, na mistura de diferentes artes em um mesmo espetáculo, não é nova. No século XVII, "dança e ópera comungavam uma mesma noção de espetáculo, cunhada no Renascimento, que advogava a fusão de diferentes artes em uma só" (KATZ, 2010, p. 164). E no século XVIII, nos vaudevilles, já eram presentes música, dança e teatro, no compartilhamento de diferentes procedimentos temporais em um mesmo espetáculo.

Mas as especializações das artes provocam outros olhares em relação à hibridização de disciplinas na integração entre os campos do conhecimento e da arte. Por exemplo, das artes visuais, com o desdobramento de categorias bem definidas tais como desenho, gravura, escultura e arquitetura na Idade Moderna, no fim do século XIX, bem como as especializações das linguagens artísticas que se apresentam no século $X X$, com o modernismo.

Em dança, a ação Untitled Event (1952), criada pela iniciativa de John Cage, acompanhado pelo bailarino Merce Cunningham e pelo artista visual Rauschenberg, por exemplo, traz "uma proposição pluridisciplinar que envolve música, poesia, pintura, dança, palavra, projeção de dispositivos..." (ROUX, 2007, p. 25) ${ }^{64}$.

Contudo, compreendemos que é no século XXI que as proposições de dança aumentam a taxa de complexidades entre as disciplinas artísticas. A mistura e a hibridez entre as linguagens trazem novos graus de complexidade às temporalidades. As fronteiras entre as linguagens estão cada vez mais móveis. Ao mesmo tempo em que há especificidades entre as linguagens - por exemplo, da dança e do teatro -, há também uma contaminação entre os procedimentos espaçotemporais de cada uma que alteram linguagens e formatos artísticos anteriormente definidos como natureza desses campos, considerados separadamente.

A característica relacional de temporalidades colabora para outros formatos de apresentação, como podemos observar no espetáculo Emmy + Avenir, do coreógrafo e antigo diretor do Centro Coreográfico Nacional de Tours, Daniel Larrieu. Ele propôs um espetáculo de dança combinado a uma espécie de conferência.

\footnotetext{
${ }^{64}$ Tradução nossa a partir do original: "Untiled Event est une proposition pluridisciplinaire faisant participer musique, poésie, peinture, danse, parole, projection de dispositives..." (ROUX, 2007).
} 
Na ocasião da $40^{a}$ edição do Festival Les Hivernales, de Avignon, na França, no dia 25 de fevereiro de 2017, esse espetáculo foi exibido no Théâtre Glovine. A apresentação foi composta por uma leitura, acompanhada da apresentação de fotos projetadas por vídeo-imagens acerca do trajeto de 30 anos como dançarino. A apresentação, além de contar com a fala de Larrieu nas duas primeiras cenas, trazia ainda a manipulação de um boneco e a interpretação/tradução do dançarino Enzo Pauchet, em uma ideia de transmissão do solo Emmy, criado e interpretado por Larrieu em 1993. O espetáculo de dança foi contaminado pela linguagem de conferência.

Esse é um exemplo de como os formatos espetáculo de dança, conferência, performance, teatro e audiovisual se misturam em uma dramaturgia, numa espécie de desterritorialização das artes. Os procedimentos temporais ultrapassam a fronteira entre as linguagens.

Os procedimentos temporais próprios a determinada linguagem artística cada vez mais têm permeado e atravessado outras linguagens e formatos. Nesse sentido, a expansão de temporalidades e de procedimentos temporais possibilita diferentes modos de apresentar um pensamento artístico, como propôs Larrieu com seu espetáculo de dança entremeado a um formato de palestra.

Nesse sentido, a dramaturgia do corpo não é segregada, ela está no campo da arte e "a arte é, por essência, nômade" (BERNARD, 2001, p. 22). Ela necessariamente interfere em outras formas porque implica uma corporeidade entrelaçada a "uma perpétua viagem, a uma errância infinita" (BERNARD, 2001, p. 22).

As qualidades espaçotemporais que um artista criador organiza partem de elaborações motoras, perceptivas e cognitivas de diferentes informações. São temporalidades que compõem suas escolhas coreográficas e abrem caminho para a singularidade de um modo de se comunicar. Na medida em que um corpo traz um questionamento acerca do ambiente em que vive, um pensamento específico é articulado, uma qualidade de agir é gerada, de acordo com o tempo em que esses questionamentos surgem. Nesse sentido, as temporalidades envolvem singularidades na problematização de procedimentos a partir de experiências vivenciadas e da reflexão sobre elas, questionamentos que ultrapassam formatos. A dramaturgia do corpo lida, assim, com procedimentos e qualidades temporais que podem extrapolar um determinado formato de dança, podendo qualificar-se como 
evento performativo, por exemplo, como veremos mais adiante. Ademais, as temporalidades pensadas por um artista do corpo, elaboradas em uma composição coreográfica, apresentam certas características específicas que abordaremos a seguir. 
2.5 Temporalidades que surgem na e pela composição coreográfica

O processo de agenciamentos de temporalidades se dá por meio de uma composição de dados temporais, ou seja, trata-se, para além de sua criação, de procedimentos combinados, rearticulados, sobrepostos e entrecruzados. A composição de temporalidades é a todo momento atualizada por adaptações e pensamentos que levam em conta as possíveis variações e imprevisibilidades desse processo. Buscamos abordar aqui a ideia de que os procedimentos espaçotemporais apenas podem ser feitos de acordo com os elementos que surgem na composição e pela composição. Isso porque "a composição implica a distribuição de estados e de linhas de força ou de tensão a partir de dados corporais" (LOUPPE, 2012, p. 224). Ela é um exercício que parte da invenção singular do movimento e não se elabora a partir de um vocabulário já fixado (LOUPPE, 1997-2004, p. 211).

De acordo com Fontaine (2017), a composição é fundamental em dança, porque ela consiste em organizar, reunir, arranjar e combinar os elementos coreográficos no espaço e no tempo. Ela trata do tema escolhido, do modo de fazer, da forma futura do espetáculo, assim como ela permite escolher como a dança distribui o tempo da representação (Informação verbal). ${ }^{65}$

Esses entendimentos de composição ajudam a perceber que é no momento da composição que o processo de agenciamentos dos dados espaçotemporais de uma dança vai ganhar forma, ou seja, um modo específico de articulação, e que é no tempo da feitura da composição que as temporalidades irão ser combinadas e estruturadas para o compartilhamento com o espectador. Mas elas não se restringem apenas ao momento da composição, pois na apresentação do espetáculo ocorrem novas relações com o espectador, por meio das quais elas também se atualizam.

De acordo com Lepecki (2011), os arranjos dos elementos coreográficos, tais como a maneira de se mover, a espacialidade do movimento, a coerência de um

\footnotetext{
${ }^{65}$ Fala de Geisha Fontaine em aula no Pôle Enseignement Supérieur Musique / Danse. Bordeaux - França. Dia 10 de outubro de 2017: "la composition est fondamentale en danse, car elle consiste à organiser, rassembler, arranger et combiner les éléments chorégraphiques dans l'espace et le temps. Elle concerne le thème choisi, la manière de faire, la forme future du spectacle. Elle permet de choisir comment la danse distribue le temps de la représentation."
} 
gesto, a construção de um passo ou uma frase de movimento correspondem a uma "tensão que se estabelece entre múltiplos processos de pensamentos e múltiplos processos de atualizações" ${ }^{\prime 66}$ (p. 167).

Mesmo que as compreensões de composição supracitadas nos tragam um entendimento que se relaciona com a dramaturgia, a composição também toma um viés processual dos modos temporais de estruturação que o movimento assume. Esse entendimento de composição difere do entendimento de composição controlada.

Ao longo da história da dança, regras de composição de antemão construídas foram utilizadas por diversos coreógrafos e dançarinos, regras que trazem um entendimento de composição controlada. Mas observar certas normas de composição outrora adotadas permite observar diferenças entre os entendimentos de composição com relação aos dias de hoje. Observar certas regras de composição pode também instigar novas maneiras de disposições dos elementos coreográficos. Isso não quer dizer que há um determinado jeito de combinar temporalidades, até porque existem infinitos modos de criação dos dados temporais de um trabalho e os procedimentos espaçotemporais apenas podem ser feitos de acordo com os elementos que surgem durante a composição, mas observar certas regras de composição amplia a percepção para os modos de articulação temporal já abordados pelos coreógrafos.

Por exemplo, o compositor musical e colaborador da dançarina moderna Martha Graham (1894-1991), o americano Louis Horst (1884-1964), que endossou os princípios da dança moderna, nos apresenta uma ideia de composição controlada que é associada à música. Ele apresenta regras planejadas de antemão que o coreógrafo e o dançarino devem aplicar "quase inconscientemente" (HORST, 1998, p. 46), pela apreensão de formas repetidas.

Segundo Horst (1998), o termo composição significa "colocar ou situar certas partes de um todo em relação a outros elementos" 67 (p. 46). A composição se baseia, para ele, na escolha de um tema e ensaios que devem seguir leis de

\footnotetext{
${ }^{66}$ Tradução nossa a partir do original: "Desde mi punto de vista, la tensión que alimenta y posibilita la dramaturgia como una práctica de la danza, para la danza y con la danza, es la tensión que se establece entre múltiples procesos de pensamiento y múltiples procesos de actualización".

${ }^{67}$ Tradução nossa a partir do original: "Le terme 'composer' signifie poser ou situer certaines parties d'un tout par rapport à autres éléments."
} 
manipulação dos elementos desse tema, tais como: a repetição, a inversão, a amplificação e a contração.

Por exemplo, na forma A B A, há "um começo, um meio e um fim, o tema é anunciado no A, depois é manipulado; B é um tema contrastante e, depois de sua manipulação, o final constitui um retorno ao $A$, provavelmente sobre um aspecto diferente"68 (HORST, 1998, p. 47).

Como exemplo dessa estrutura que ele denomina tema e variações, há o seguinte:

Se A comporta um giro, é necessário outro movimento em B sem giro. Se os movimentos anteriores aparecem no tema original, é melhor focar o tema secundário sobre o chão. A parte $B$ é menos importante que a parte $A$, mas é necessário prevenir de variações, a fim de evitar a monotonia. (1998, p. 48)

Além dessa estrutura global, há outros elementos da composição que o autor considera interessantes, ao adicionar, por exemplo, o elemento C: A B C A B, ou A B C B A, ou de alternância, como A B A C A D A E A F A, ou B C D E. Apontamos esses exemplos para observar diferentes pontos de vista em relação à composição em dança, e perceber um entendimento temporal ligado a essa noção de composição. A ideia de uma composição controlada também é abordada pela dançarina moderna Doris Humphrey (1895-1958), que discorre sobre algumas regras para a composição, dentre elas: evitar buscar a simetria, no que tange à estabilidade do equilíbrio do movimento. A simetria, segundo a dançarina, traz uma forma "sem vida" (1998, p. 52) para a composição.

Para ela, também é importante utilizar todas as dimensões do corpo (HUMPHREY, 1998, p. 53) e evitar ser "escravo" da música. Outro fator que aponta em relação à dinâmica: quando a dança é construída em uma sala ou estúdio, e depois realizada no palco, a distância modifica quase todos os elementos dessa dança. Isso porque, no palco, é possível observar o todo em um relance de olhar, até mesmo sem mudar o ponto focal, o que não acontece no estúdio ou sala de dança, por conta da distância. Segundo Humphrey, os pequenos movimentos e os

\footnotetext{
${ }^{68}$ Tradução nossa a partir do original: "La forme esthétique la plus instinctive est l'A B A ; um début, un milieu et une fin. [...] La premier thème est énonce dans le $A$, puis il est manipulé; $B$ est un thème contrastant et, après sa manipulation, le final constitue un retour à $A$, probablement sous un aspect légèrement différent." (p. 47)
} 
detalhes não são mais visíveis de perto (p. 54). Por conta da distância, eles ganham maior visibilidade de longe, portanto, no momento da composição, é importante observar esse aspecto.

Outra sugestão de Humphrey para coreografias que parecem muito longas é o corte ou a supressão, que podem trazer um material coreográfico mais rico e intenso (p. 55). Além disso, é preciso atentar para o final da composição. Segundo ela, "o fim é uma questão de grande importância; os coreógrafos deveriam se preocupar com isso como fazem os dramaturgos com o terceiro ato" (p. 55). Para ela, um bom fim representa quarenta por cento da dança e, "se ele se junta a uma interpretação imaginativa, esse será duas vezes mais estimulante" (HUMPHREY, 1998, p. 56).

Essa "lista de controle" apresentada por um pensamento da dança moderna possibilita refletir sobre um determinado entendimento de composição, o que nos parece diferente de uma estrutura elaborada pelas informações e devires que o processo de trabalho coreográfico contemporâneo geralmente desenvolve. Mas, ao mesmo tempo, essas "regras" podem agir como disparadores de criação, sugerindo outras formas de se fazer a partir dessas delas. Isso vem ao encontro de questionamentos frequentes de coreógrafos diante da melhor forma de organizar os materiais de uma composição no tempo espaço da cena, na duração de um espetáculo.

Atualmente, a composição é cada vez mais explorada, não por definições a priori, mas por devires imprevisíveis incorporados à composição. O pensamento contemporâneo da dança parece implicar a necessidade de criação de temporalidades, pois o corpo dançante engendra uma duração ordenada de maneira singular pela sua motricidade, uma duração que é engendrada segundo a urgência das necessidades imediatas de cada corpo. Isso porque "o corpo dançante não cessa de se dissolver e de se reconstituir na sucessão dos seus instantes, no fluxo de uma temporalidade não controlável”69 (BERNARD, 2001, p. 80).

Para Bernard, a dança é ato de metamorfoses. Diferentemente de um único jeito de operar, ela lida com a possibilidade de transformação, de multiplicidades e de diversidades de corporalidades. Uma dança é promovida pelas ininterruptas

${ }^{69}$ Tradução nossa a partir do original: "le corps dansante ne cesse de se dissoudre et de se reconstituer dans la succession de ses instants, dans le flux d'une temporalité non maîtrisable qu'il essaie pourtant d'imaginer et même de visualiser. L'instant engendre la forme, et la forme fait voir l'instant." 
metamorfoses nos deslocamentos, movimentos, atitudes e mudanças de direções; em dança, "a dinâmica se oferece como um jogo aleatório e paradoxal de construção e desconstrução, ou melhor, de entrelaçamentos e desentrelaçamentos da temporalidade que explodem a corporeidade em acontecimentos" ${ }^{\text {"70 }}$ (BERNARD, 2001, p. 88).

Contrapondo-se a uma ideia de composição controlável, o bailarino e coreógrafo norte-americano que transformou os rumos da dança moderna, Merce Cunningham $^{71}$ (1919 - 2009), explorou procedimentos temporais relativos ao acaso e ao imprevisível na composição coreográfica. Ele desenvolveu noções temporais de descontinuidade, variabilidade e instabilidade compreendidas na ideia de impermanência em dança.

Para ele, as características do não-permanente, do evanescente e do efêmero são qualidades decisivas na dança. Em seu texto "A arte impermanente", escrito em 1955, Cunningham concebe o elemento da impermanência em sua dança. Segundo ele, "a dança se ancora no instante em que se apresenta, e sua vitalidade, o seu poder e sua sedução provêm justamente do caráter único do instante. Ela é, assim, justa, impermanente como a respiração" ${ }^{72}$ (FONTAINE, 2004).

Para ele, o dançarino lida com durações de permanentes fluxos (1965), pois "dança é movimento, e suas oposições no tempo e no espaço estão em mudança contínua, fato que possibilita sua estrutura, sua permanência na fluidez" ${ }^{73}$ (JOHNSTONE, 1966, p. 2). Cunningham aborda a duração correspondente a um

70 Tradução nossa a partir do original: “C'est le cas plus particulièrement du spectacle chorégraphique dont la dynamique s'offre comme un jeu aléatoire et paradoxal de construction et destruction mieux de 'tissage et détissage' de la temporalité qui fait éclater la corporéité 'en événements"' (BERNARD, p. 88).

71 "Merce Cunningham fornecerá à dança um conhecimento de seus materiais específicos: tempo, espaço, energia, seus componentes e combinações. [...] O coreógrafo rompe assim uma organização cênica que datava de cinco séculos (perspectiva, visão frontal)". Tradução nossa a partir do original: "Cunningham fournira à la danse une connaissance de ses matériaux spécifiques: temps, espace, énergie, leurs composants et leurs combinaisons. [...] Le chorégraphe casse ainsi une organisation scénique qui datait de cinq siècles (perspective, vision frontale)." (CRÉMÉZI, 1997, p. 13).

${ }^{72}$ Tradução nossa a partir do original: "la danse s'ancre l'instant qui se présente et sa vitalité, sa puissance et sa seduction proviennement justement du caractère unique de l'instant. Elle est aussi juste, et impermanente quel la respiration."

${ }^{73}$ Tradução nossa a partir do original: "Dance is movement, and its opposite, in time and space. It is this continuously changing fact that gives its structure - its permanence in fluidity - and provides a fascination that impels a good many people to be concerned with it: choreographers, performers, teacher, ad spectors". 
movimento ou a uma frase de movimentos por encadeamentos, não de modo linear ou métrico, mas sim por temporalidades descentralizadas e policrônicas.

Diferentemente de um tempo global, ele explora construções temporais em um jogo de relações; embora os processos de trabalho ocorram com o emprego do cronômetro, isto é, de uma limitação do tempo, esse tempo cronométrico é desordenado pela construção de procedimentos variados que se desdobram de diferentes maneiras.

Segundo Fontaine (2004), o processo de trabalho de Cunningham se apoia em quatro escolhas que instituem novos modos temporais em dança: a independência da dança e da música apresentada na duração de um espetáculo, a utilização de procedimentos aleatórios, a realização de filmes de dança e a utilização de software na construção de suas coreografias.

\begin{abstract}
Ele recusa o esquema de introdução, desenvolvimento, conclusão. Não constrói uma organização temporal de sua dança segundo a exposição de um tema e o tratamento de suas variações. Ele não privilegia um momento forte (clímax), cada instante é tão importante quanto o outro. As transições entre os movimentos são pouco visíveis em sua dança. Numerosos pequenos acontecimentos aparecem e desaparecem. Todos os acontecimentos parecem importantes. ${ }^{74}$ (FONTAINE, 2004, p. 75)
\end{abstract}

Há, em suas obras, uma diversidade de temporalidades que se entrecruzam, que não são lineares e nem métricas. Ele elabora novos agenciamentos temporais por procedimentos aleatórios e de informática, os quais, na contramão de uma construção linear ou métrica, manifestam uma descentralização do tempo, assim como o artista faz com o espaço. Essa abordagem apresenta uma forma de descontinuidade, questionando um desenvolvimento temporal pré-existente.

Essas temporalidades do acaso e do imprevisível são percebidas por Cunningham sob a perspectiva de que o "instante é um fragmento que contém conexões com outros fragmentos, um ponto onde se pode ver toda a estrutura de um pensamento" coreográfico (SANTANA, 2002, p. 86). A relação entre as atualizações e a dança é íntima porque envolve o movimento pela sua própria

\footnotetext{
${ }_{74}$ Tradução nossa a partir do original: "Il refuse le schéma introduction, développement, conclusion. II ne construit pas l'organisation temporelle de sa danse selon l'exposition d'un thème et le traitement de ses variations. II ne privilégie aucun moment fort (climax), chaque instant est aussi important qu'un autre. Le transitions entre les mouvements son peu visibles dans sa danse. Nombre de petits événements apparaissent et disparaissent. Tout ce qui advient semble important".
} 
possibilidade de mudança. E "toda transformação é signo de um processo temporal"75 (FONTAINE, 2004, p. 119).

Se uma coisa em dança existe em seu tempo e seu lugar, sem a necessidade de uma "representação" ou símbolo dela mesma, como afirma Cunningham, o aspecto temporal em dança não lida com uma continuidade linear progressiva de um evento A que necessariamente seja prosseguido por um evento B. A dança lida com um descentramento temporal de cruzamentos de tempos presentes que incluem o instante, carregado de memórias que se atualizam incessantemente, além do vir a ser.

Cunningham foi um dos precursores na investigação da relação espaçotemporal, trabalhando com o acaso, a não-linearidade e a descentralização. Essa "multidirecionalidade" (AMORIM; QUEIROZ, 2000, p. 100) explorada pelo coreógrafo traz a percepção espaçotemporal de múltiplos sentidos e direções, que se interligam de forma simultânea e mutável.

Ele não lida com uma narrativa de continuidade de uma "representação", que se refere a algo que não está lá no momento presente de sua apresentação, no sentido de a dança residir em outro lugar que não o da própria dança. Ele lida, isto sim, com uma dramaturgia de dança que se concretiza por saltos ${ }^{76}$. "Para Cunningham, o tempo não se sobrepõe ao movimento; ele provém da verdadeira essência do movimento" (LOUPPE, 2012, p. 151). Ou seja, para ele, uma coisa em dança existe em si mesma e em seu tempo e lugar, sem a necessidade de se referir a outra coisa ou ao símbolo. A experiência do dançarino lida com a emergência do movimento, no momento presente de sua elaboração, "se afina de acordo com a vida descontínua, fragmentada do tempo à 'impermanência' descoberta por Cage e Cunningham."77 (LOUPPE, 2007, p. 16).

Nessa perspectiva, o corpo em dança não lida com a previsibilidade de um movimento que necessariamente será causado por outro, não há uma relação de causa e efeito, em termos de definir uma sucessão ou continuidade linear de um movimento para o outro. A ideia de um tempo não linear pode ser percebida na

\footnotetext{
${ }^{75}$ Trad. nossa a partir do original: "Toute transfomation est signe d'un processus temporel".

${ }^{76}$ Disponível em: http://ressources.marseille-objectif-danse.org/IMG/pdf/l_art_impermanent.pdf Acesso em: 14 abr. 2016.

77 "La notion de present scintilla dans l'expérience du danseur, elle est le cadre temporel de l'émergence d'un geste fugitif - et, dans l'improvisation, unique -, sans retouche et non renouvelable. Le present s'accorde en tant que vie discontinue, fragmentée du temps à 'l'impermanence' découverte par Cage et Cunningham".
} 
afirmação do coreógrafo: o corpo em dança articula "informações do passado, reescritas pela sua história, e informações que propiciariam um futuro" (SANTANA, 2002, p. 85).

A construção de temporalidades em dança se realiza, assim, pela característica temporal do imprevisível e do provisório na composição de ações do corpo, elas estão em constante processo de transformação e de adequação, inclusive após a estreia, que implica a relação com o público. Elas são realizadas por um processo ativo e constante de construir informações. A organização de procedimentos temporais abrange desde a composição à apresentação de uma obra. As temporalidades constituídas por qualidades temporais no desenvolvimento de um trabalho artístico intervêm tanto na composição de uma coreografia quanto nos elementos cênicos que essa proposição coreográfica agencia. Diferentemente de um tempo global, as temporalidades assumem uma forma particular de articulações temporais dadas pelo campo de relações solicitadas no próprio processo de feitura da obra. 


\section{Temporalidades percebidas em obras de dança}

Com o intuito de observar como o entendimento de temporalidades proposto nesta pesquisa pode viabilizar uma dramaturgia em dança, abordamos neste momento certos procedimentos espaçotemporais percebidos em quatro obras coreográficas: Danças Passageiras (2013), concebida pela coreógrafa brasileira Zélia Monteiro; Esculturas Breves (2015) e Brevidades (2016), concebidas pela coreógrafa brasileira Helena Bastos e Nó(s) (2016), processo de criação do qual participei como coreógrafa. Com esses exemplos de trabalhos criados no século $\mathrm{XXI}$, percebemos certas questões e noções temporais articuladas em dança atualmente.

Observamos, em tais obras, procedimentos espaçotemporais específicos que portam imprevisibilidades, questionamentos e complexidades com uma capacidade crítica de fazer dança que escapa a formas de antemão determinadas.

No subcapítulo anterior, abordamos alguns entendimentos de composição em dança, um entendimento de composição controlada e uma abordagem de composição promovida pelo acaso, proposta por Cunningham. Mas há ainda a improvisação, que lida com imprevisíveis desdobramentos, tanto para a elaboração de um processo de criação, quanto como modo de composição. A improvisação em dança tende a explorar as temporalidades da atenção, prontidão e escuta de micro e macro mudanças corporais, uma percepção temporal específica implicada nas escolhas e decisões da ação no tempo presente, segundo as articulações e percepções possíveis organizadas por cada corpo. A improvisação como modo de composição está diretamente ligada aos fatores temporais do instante e da gravidade, que, por sua vez, age entre os hábitos que não esquecemos, nas soluções imediatas que o corpo toma e no reconhecimento de cada ação pela consciência, entrecruzando presente, passado e futuro.

A improvisação como modo de composição é trabalhada no solo Danças Passageiras, dirigido e dançado pela bailarina e coreógrafa brasileira Zélia Monteiro. Contudo, há diversos modos de trabalhar a improvisação, justamente porque ela supõe a percepção de alguém, o que coloca em jogo, no momento presente da 
elaboração do movimento, os hábitos de um corpo, suas experiências, habilidades em dança e sua história de vida.

De 1984 a 1992, Zélia Monteiro foi aluna e trabalhou como bailarina e assistente do bailarino, coreógrafo e professor Klauss Vianna (1928-1992), artista da dança de grande referência no Brasil. O trabalho com Klauss em expandir a percepção das tensões musculares sobre a movimentação, em não buscar passos estabelecidos de antemão e "chegar o mais próximo possível de um gesto espontâneo"78, ressoa até os dias de hoje na sólida pesquisa em improvisação voltada para a composição que Zélia desenvolve. Segundo ela, "a atenção na construção do movimento no corpo [...] amplia as possibilidades de continuidade deste gesto de alguma forma iniciado, dando-lhe condições de liberar-se de automatismos" (MONTEIRO, 2008, p. 61) ${ }^{79}$. A exploração do movimento e do gesto no tempo presente, aguçada pela atenção entre o que acontece internamente no corpo e as informações que o cercam, é trabalhada por procedimentos temporais específicos na composição de Danças Passageiras.

As temporalidades implicam questionamentos, que, por sua vez, são produtoras de complexidades. Elas se compõem por uma viscosidade temporal diretamente processada no contexto em que o corpo vive, como é o caso das temporalidades percebidas em Escultras Breves e Brevidades, concebidas e dirigidas pela coreógrafa brasileira Helena Bastos. Nessas obras, o mover artístico é gerado por questionamentos e desafios nas escolhas e decisões de ações performativas com e no ambiente urbano.

Helena Bastos busca um discurso artístico coreográfico contemporâneo baseado no processo. Diferentemente de ter como objetivo um fim, esse discurso se configura através dos próprios meios, que já seriam o seu fim. Em outras palavras, o que interessa não é um resultado final, mas sim as diversas possibilidades do agir nas decisões que o corpo toma na urgência de uma experiência com e no espaço urbano.

As temporalidades desses processos surgem da reflexão e dos questionamentos, ao se debruçar de maneira prática sobre as escolhas e interrogações que vão surgindo: "é no próprio processo que vai desenvolvendo para

\footnotetext{
${ }^{78}$ Disponível em: http://enciclopedia.itaucultural.org.br/pessoa15340/zelia-monteiro. Acesso em: 09 jan. 2019.

${ }^{79}$ Revista Sobre o imprevisível, parte do projeto Sobre o Imprevisível, contemplado pela $7^{\circ}$ edição do Fomento à Dança.
} 
seu criador sobre que discurso está-se aprontando" (BASTOS, 2017, p. 85). Esses trabalhos envolvem um pensamento crítico em dança que não é elaborado por uma mensuração espaço-temporal, isto é, não seguem uma linha que começa em determinado ponto e acaba em outro. Eles são construídos de modo processual, ao longo de cada experiência, transformados a cada vez que as informações da cidade entram em relação direta e imprevisível com o corpo. Em Esculturas Breves e Brevidades, as temporalidades aparecem ao se qualificar ações diante de um ambiente e tempo percebidos por cada um dos performers. Helena Bastos traz questionamentos acerca do tempo atual vivenciado no ambiente capitalista, por meio do enunciado "corpo sem vontade", que, por sua vez, aparece desde 2006 em seu trabalho Vapor, questionando a vontade produtivista que se alinha a parâmetros quantitativos no ambiente.

As temporalidades percebidas por seu caráter relacional também são observadas nos procedimentos construídos no processo de criação de Nó(s), do qual participei como coréografa e dançarina. A construção e a combinação de fatores temporais para o compartilhamento com o outro possibilitaram as estratégias deste trabalho.

As seleção dessas obras abordadas na pesquisa, além de levarem em conta os nomes dos trabalhos que implicam temporalidades, operaram em razão de minhas próprias experiências, afetos e entendimentos de dança, bem como pela admiração pelas artistas Helena e Zélia. Além de ser orientanda da professora Helena, tive a oportunidade de participar das instalações coreográficas de Esculturas Breves e Brevidades. Fui aluna também de Zélia, no período de 2000 a 2004 em seus cursos de balé clássico, e pude assistir a Danças Passageiras ao vivo. 


\subsection{Dramaturgia do instante em Danças Passageiras}

Com o intuito de observar as temporalidades implicadas na dramaturgia de Danças Passageiras (2013), abordamos certos fatores temporais percebidos na obra concebida pela coreógrafa e bailarina Zélia Monteiro. O solo se especifica pela criação e combinação de temporalidades como um pensamento articulado da obra. Segundo ela: "Danças Passageiras é apoiada na questão das temporalidades"

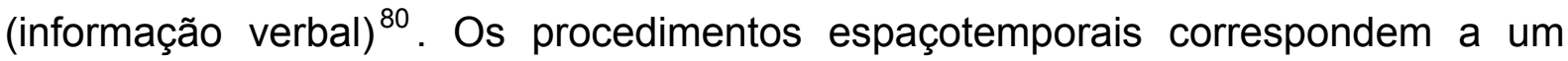
modo específico de pensamento na elaboração dos movimentos dançados, que viabilizam sua dramaturgia do instante.

As temporalidades apresentadas na obra permitem expandir o entendimento de dramaturgia, na medida em que se manifestam sob outros formatos coreográficos, diversos daqueles habitualmente conhecidos através de definições a priori. Danças Passageiras é construída pelas emergências do movimento na improvisação, no momento presente em que essas emergências se processam no instante.

Temporalidades do instante são combinadas na obra com outros fatores temporais, como, por exemplo, a métrica irregular que conecta impulsos e pulsos indeterminados e provisórios. A obra é construída por uma dramaturgia na qual não são definidos de antemão começo, meio e fim na duração do espetáculo, não há uma pré seleção dos movimentos a serem feitos ou um roteiro prévio de espaço. No compartilhamento presente com o espectador, temporalidades do instante são elaboradas a partir da imensa e significativa pesquisa na linguagem da improvisação de Zélia Monteiro.

Além de Zélia ter trabalhado por oito anos como assistente de Klauss Vianna, ela foi aluna e assistente da mestra de balé italiana D. Maria Meló (1911-1993) por nove anos, de 1977 a 1985, em São Paulo. Através dessa experiência, Zélia aprendeu e trabalha até os dias de hoje com a técnica Cecchetti de balé. Justamente a partir dessas referências, apoiadas no desenvolvimento e aprimoramento tanto do balé quanto da improvisação, a coreógrafa tem seu trabalho marcado por especificidades em coreografias solo e como diretora do Núcleo de

\footnotetext{
${ }^{80}$ Resposta à entrevista à Tatiana Melitello Washiya. São Paulo, 2018.
} 
Improvisação de dança.

Uma das singularidades que se destaca na dramaturgia de Danças Passageiras é a exploração do instante baseada na mencionada pesquisa de improvisação de Zélia. Lembramos que a improvisação como um modo de composição é trabalhada por cada coreógrafo de maneira singular. Há diversos modos de trabalhar a improvisação, justamente porque ela supõe a percepção de alguém, o que coloca em jogo, no momento presente da elaboração do movimento, os hábitos de um corpo, suas experiências, habilidades em dança, sua história de vida.

Segundo Zélia, "a capacidade de organizar no instante um discurso coreográfico traz para esse trabalho temporalidades que centram no momento presente, na percepção do que emerge e rompe na instantaneidade" ${ }^{81}$. A instantaneidade de Danças Passageiras é combinada com a memória, pelos gestos elaborados por lembranças, e a partir de imagens que impulsionam seus movimentos.

O instante, a memória e os fluxos imagéticos participam dos impulsos corporais trabalhados na obra. São elementos constitutivos da dramaturgia de Danças Passageiras porque se apresentam como estratégias temporais que organizam a obra.

Esses procedimentos temporais, compostos pela memória, pelo fluxo de imagens, pelo instante e pela duração, envolvem o risco do indeterminado. A indeterminação e a abertura de imprevisibilidades podem levar a um não saber ou mesmo provocar uma reação ansiosa face a essa indeterminação. Em Danças Passageiras, contudo, o risco é trabalhado por constantes decisões, pelas escolhas que a coreógrafa realiza a todo momento na cena.

Embora Danças Passageiras não gire em torno da linguagem do balé, a memória corporal dessa técnica acontece por um conhecimento incorporado no e pelo corpo de Zélia. Além dessa memória incorporada pelo hábito cotidiano de estudos da técnica do balé, a memória em si se configura como um procedimento de criação relevante no trabalho de Danças Passageiras. Isso porque a obra explora o reconhecimento de certas organizações motoras, como, por exemplo, o hábito de andar, comer e se mover. Ela lida com o reconhecimento de uma dinâmica corporal

\footnotetext{
${ }^{81}$ Resposta de Zélia Monteiro, entrevista por Tatiana Melitello, junho 2018.
} 
cotidiana, bem como a percepção e observação das musculaturas mais sutis e profundas do corpo, implicadas em sua memória organizacional motora, ao realizar essas ações.

A memória como uma qualidade de elaboração temporal, aqui compreendida como temporalidade da memória, implica o hábito. O hábito envolve a memória e a repetição, uma relação que "desenvolve, a cada tentativa, movimentos enredados; a cada vez chama a atenção do corpo para um novo detalhe que havia passado despercebido" (BERGSON, 1990, p. 89). Trata-se de uma relação que se atualiza pelo esquema motor assim que o corpo realiza um movimento.

As temporalidades da memória permitem a construção de uma dança porque possibilitam a criação de esquemas mentais (YATES, 2008). São disparadoras de imagens na medida em que a memória opera por meio de cadeias associativas (CARRUTHERS, 2011).

Em Danças Passageiras, a memória corporal de Zélia entra em jogo para suas permanências no instante. A memória age no tempo presente pelos reconhecimentos dos próprio gestos da dançarina. Diferentemente de trabalhar com uma improvisação que se direciona a rupturas de hábitos, ela explora a percepção dos hábitos que interferem nas posturas e musculaturas profundas do corpo, como uma estratégia de duração na improvisação.

O parâmetro temporal da gravidade também age nesse processo. Além de requerer uma qualidade temporal de atenção e escuta do próprio corpo durante o movimento, a gravidade age entre os hábitos que não esquecemos, nas soluções imediatas e no reconhecimento de cada ação pela consciência, entrecruzando presente, passado e futuro. Ou seja, uma ideia que envolve a memória vinculada a um estado presente do corpo.

A gravidade acontece na escuta do próprio corpo: quando tomamos consciência da tensão em uma certa musculatura, por exemplo, o corpo será modificado pela percepção das alterações de seu peso, mas isso leva tempo. A gravidade permite a sustentação, projeção e a resistência com as oposições geradas ao empurrar o chão. Segundo Klauss, esses três elementos que participam da intenção de um gesto invariavelmente implicam a gravidade. Ele explica que "a resistência vai abrindo espaço entre os ossos, seguindo sua direção nas articulações" (VIANNA, 2005, p. 93). O movimento e suas sustentações podem surgir dessas forças opostas. Na medida em que há o trabalho com o chão, espaços 
internos se expandem, permitindo as projeções desse movimento para o exterior.

Duas forças opostas geram um conflito, que gera o movimento. Este, ao surgir, sustenta-se, reflete e projeta sua intenção para o exterior, no espaço. No corpo, esse fenômeno se inicia no momento em que descubro a importância do solo e a ele me entrego e o respeito. (VIANNA, 2005, p. 93)

Além da gravidade, outra questão temporal trabalhada em Danças Passageiras é o impulsionamento de fluxo de imagens, que, no momento presente, carrega passados e expectativas futuras. Não se trata de uma imagem prévia, pronta, como uma fotografia por exemplo. Pelo contrário, as imagens são elaboradas no momento da improvisação, elas são construídas por Zélia a cada espetáculo, variam segundo cada apresentação. Para ela, as imagens são o que se passa na mente no momento da cena, são imagens relacionadas a pensamentos, ideias, lembranças e imaginação.

Em Danças Passageiras, esses impulsos imagéticos atravessam em fluxo os movimentos de Zélia. Segundo ela, são impulsos de toda ordem de imagens, desde a percepção de um pensamento que a atravessa naquele momento, a percepção de sensações como a tristeza, alegria ou o medo, por exemplo, ou mesmo a da fisicalidade de uma transferência de peso, que pode estar distribuído em uma determinada parte do corpo.

Os fluxos imagéticos trabalhados em Danças Passageiras lidam com pensamentos e ideias, e, nesse sentido, são imagens variáveis, que carregam uma temporalidade na medida em que há nelas a característica da metamorfose. Não apenas pelas lembranças, mas também pela imaginação que é produzida, dependendo do sujeito que a configura e reconhece, de acordo com diversas formas de significações. São imagens que variam incessantemente, atuando como uma temporalidade que permite a comunicação com o espectador. Trata-se, assim, de temporalidades que também implicam as percepções do dançarino e do espectador, as quais evidentemente não são as mesmas.

A dramaturgia do instante, nessa obra, torna-se visível pelas estratégias que Zélia desenvolve para se manter no presente. "Eu não coreografo previamente, eu coreografo diante do público, o que eu estudo não só para esse trabalho, mas o que eu estudo em geral é fazer improvisação cênica, que não deixa de ser uma 
coreografia do instante", afirma Zélia (Informação verbal) ${ }^{82}$. Essa temporalidade do instante aparece na dramaturgia de Danças Passageiras como um pensamento de improvisação organizado de modo coerente entre as estratégias corporais e as concepções cênicas, como a iluminação e a sonoplastia.

As concepções de luz e de som são também improvisadas a partir do diálogo entre esses materiais cênicos e as estratégias corporais criadas por Zélia. A construção da dramaturgia é concebida, em todos os trabalhos da coreógrafa, por um processo de diálogo de elaborações de questões conjuntas entre os profissionais que trabalham no espetáculo. Por exemplo, o instante, trabalhado em Danças Passageiras, também se apresenta com uma concepção de iluminação realizada por certas escolhas de ritmos, paletas e recortes de luz em diálogo com as estratégias corporais adotadas por Zélia.

A iluminação do espetáculo é elaborada por um pensamento de construção de imagens que lida com a íris do espectador. A iluminação, juntamente com as ações corporais, provocavam em muitos momentos uma imagem turva ou um efeito embaçado nas cenas, dando a impressão de que a coreógrafa estava suspensa no ar. Esse efeito foi trabalhado com uma luminosidade aberta por um tempo, para que a íris do espectador pudesse abrir e dilatar-se, provocando, junto com a movimentação corporal de Zélia, a impressão de uma temporalidade suspensa. A improvisação da sonoplastia acontece com entradas e saídas das texturas sonoras improvisadas conforme sua movimentação, em escolhas de um determinado elemento sonoro em detrimento de outros.

Todos esses elementos compõem a dramaturgia de Danças Passageiras, conectando e combinando diversos procedimentos temporais, em escolhas que possibilitam um modo de organização.

As escolhas são realizadas no instante, disparadas por uma sensação, lembrança ou informação no momento do espetáculo. São temporalidades que emergem da percepção e consciência de algo no momento presente da elaboração do movimento dançado. A partir de uma escolha feita por Zélia, que envolve uma consciência, ela busca uma certa permanência no instante para que seja possível o prolongamento dessa escolha e o desdobramento das ações corporais em níveis, direções e variações temporais.

82 Resposta à Tatiana Melitello Washiya. São Paulo, 2018. 
Embora o corpo seja instantâneo ao receber milhares de informações a todo momento, ele regulariza mesmo que temporariamente as suas funções. Nesse sentido, Zélia trabalha com o instante não como um modo temporal que a todo momento passa, mas como um jogo com o instante na improvisação. São com as escolhas no instante que ela prolonga uma ação em "uma temporalidade métrica irregular daquela ação no tempo"83 (Informação verbal).

A temporalidade do instante é combinada com uma temporalidade métrica irregular em Danças Passageiras. Zélia compreende uma temporalidade métrica irregular quando o impulso é percebido e realizado por um certo período, em um fluxo de duração que permite o desenvolvimento de um ritmo, de uma repetição e de uma variação, que pode ser mais curta ou mais longa, a partir de uma escolha que se deu no instante, no momento em que os impulsos corporais foram selecionados. Ou seja, a instantaneidade dos movimentos é combinada com uma temporalidade métrica. Mesmo que seja irregular, ela permite uma certa periodicidade no desenvolvimento de ritmos e variações.

Segundo ela, a temporalidade métrica implica uma certa duração, ou seja, o que emerge e o que rompe na instantaneidade é trabalhado em Danças Passageiras também por durações que permitem o prolongamento de uma ação. O instante, mas também a sua permanência, são relevantes para a dramaturgia da obra.

Quando Zélia afirma que lida com uma temporalidade métrica em Danças Passageiras, devemos atentar para o fato de que não se trata de uma métrica regular, como no balé, na qual o espaço e o tempo são definidos por múltiplos de dois, como em 2, 4, 8, 16 ou 32. Embora a métrica seja habitual na prática do balé, Zélia não trabalha com essa regularidade na improvisação.

Segundo ela, se a improvisação ficar apenas nos instantes, ou seja, se ela se der apenas pelas instantaneidades, isso não permite um mergulho na linguagem da improvisação, porque, se os movimentos estiverem circunscritos em um fluxo de mudanças que a todo momento passa, isso pode impedir o desenvolvimento de um impulso. A permanência no instante é uma estratégia que permite que uma informação seja apreendida e que haja, assim, um certo desenvolvimento coreográfico, uma variação ou um ritmo.

\footnotetext{
${ }^{83}$ Resposta de Zélia em entrevista à Tatiana Melitello, junho de 2018.
} 
Nesse sentido, quando Zélia cita uma temporalidade métrica irregular, que implica uma periodicidade de existência dos impulsos criados em combinação com a temporalidade do instante, isso ocorre no sentido de sustentação de uma ideia disparada por um impulso, para que este impulso persevere até que seja novamente atualizado.

Conforme um instante inaugura um impulso, ela o coloca em um certo período, mesmo que irregular. O impulso citado está relacionado a uma ação corporal, ele apresenta um certo estímulo ou uma força que age durante um determinado tempo. Aliás, a palavra impulso está associada a pulso, indicando intensidades rítmicas.

Por exemplo, o pulso de um batimento das artérias em que podemos sentir em intervalos desiguais. Pulso e impulso remetem a um sentido de ritmo, a uma variação do movimento, a suas expansões e recolhimentos, segundo um tempo.

O "corpo humano permite uma variedade infinita de movimentos, que brotam de impulsos interiores e exteriorizam-se pelo gesto, compondo uma relação íntima com o ritmo, o espaço, o desenho das emoções, dos sentimentos e das intenções" (VIANNA, 2005, p. 105). O impulso está relacionado a uma dinâmica temporal implicada em sustentações, resistências e projeções de um movimento.

Por envolver escolhas imediatas, a temporalidade do instante pode acarretar uma "improvisação reativa". Zélia alerta para o fato de que seja preciso atenção para que a reação implicada na instantaneidade não produza uma improvisação baseada apenas nas ações reflexo do corpo. Segundo ela, essa instantaneidade de reação do corpo não colabora para a comunicação das ideias a serem desenvolvidas na improvisação.

A reação como um movimento involuntário, que não chega ao córtex e envolve um tônus alto, trazendo respostas imediatas (como, por exemplo, ao resvalar em algo quente), dificulta um certo desenvolvimento dos impulsos escolhidos para a improvisação. Zélia afirma: "Eu preciso estar na escuta do momento presente bastante intensa para conseguir improvisar com um nível de complexidade um pouco maior, para não ser uma improvisação reativa" 84 (Informação verbal). Ela busca uma corporeidade porosa e permeável, não apenas

\footnotetext{
${ }^{84}$ Resposta de Zélia à entrevista para este estudo.
} 
para perceber diferentes tipos de informações, mas também para lidar e desenvolver cada informação e, com isso, construir um discurso de dança.

Zélia trabalha até os dias de hoje com dois diferentes modos de abordar a dança, no que se refere a termos temporais, pois o balé e a improvisação lidam com uma combinação distinta de temporalidades. O fato de Zélia ter uma formação sólida do balé; que tem como princípio a regularidade, divisões de tempos marcados e definidos de antemão, encadeamentos lineares e sucessivos; e, ao mesmo tempo, possuir um extenso percurso nos estudos em improvisação; que tem como premissas o aleatório, a irregularidade, a não linearidade e a imprevisibilidade, traz para as construções cênicas uma singularidade no que tange ao uso e combinação de uma vasta gama de procedimentos temporais.

Embora haja uma escolha por procedimentos temporais que se relacionem com sua improvisação na dramaturgia de Danças Passageiras, diferentes procedimentos temporais participam da corporalidade de Zélia. Os cruzamentos de temporalidades tão distintas no corpo agem como material para suas danças.

Zélia convidou, para o processo de criação de Danças Passageiras, os coreógrafos e dançarinos brasileiros Isabel Tica Lemos, Marta Soares e Cristian Duarte. Esses artistas colaboraram como propositores no processo para que novos desafios fossem lançados aos modos de dançar de Zélia, na observação e na provocação de seus percursos habituais, com a finalidade de a coreógrafa deixar-se contaminar por diferentes pontos de vista.

Contudo, Zélia costuma trabalhar com parcerias de longa data, que estão presentes em grande parte de suas criações, como, por exemplo, o iluminador Hernandes de Oliveira, que atua com ela há 11 anos. Outros profissionais que trabalham na dramaturgia desse trabalho desenvolvem parcerias de muitos anos com a artista, como, por exemplo, o músico Danilo Tomic e a orientadora dramatúrgica Valéria Cano Bravi.

O instante, a memória, os fluxos de imagens, a consciência de hábitos corporais, as escolhas de rupturas atuam na dramaturgia de Danças Passageiras. Essas estratégias apresentadas no tempo da cena são elaboradas por Zélia a partir de uma trajetória de 20 anos de pesquisa em improvisação. Nesse sentido, a coreografia do instante de Danças Passageiras é apresentada por um conhecimento acumulado sobre as potencialidades na linguagem da improvisação.

São estratégias que requerem muitas camadas de observação para manter a 
atenção no tempo presente. Camadas essas que envolvem sua prática com Klauss Vianna. Zélia conta que, mesmo antes de entrar em cena, ela realiza um aquecimento observando o máximo possível o que acontece no corpo - como, por exemplo, o fluxo de movimentos internos, o batimento cardíaco, a respiração, a temperatura, as sensações, as emoções. Tudo o que se passa no corpo é observado nesse processo de "aquecimento", com atenção dirigida para os elementos que possibilitam o desenvolvimento de sua movimentação (Informação verbal).

Zélia inicia essa prática de escuta do corpo antes de entrar em cena, em um aquecimento que se inicia no chão, com a gravidade, percebendo as tensões, baixando o tônus e entrando em contato com os movimentos internos coordenados pelo sistema nervoso autônomo, como movimentos gástricos, peristálticos, involuntários.

Esse processo, que demanda tempo e requer o trabalho com a gravidade, faz parte do aquecimento de Zélia. Ela parte do processo de abertura a uma permeabilidade das informações que atravessam seu corpo. O espectador que assiste à obra acompanha observando a descoberta e a exploração de seus movimentos realizados de modo preciso e delicado, em estado de permanente investigação. Segundo Zélia, é como se, contando o aquecimento que acontece por 3 horas, antes de ela entrar em cena, o público visse apenas a última meia hora do processo (Informação verbal).

Aqui, o trabalho com a gravidade é fundamental. De acordo com Klauss Vianna (2005), "só quando descubro a gravidade, o chão, abre-se espaço para que o movimento crie raízes, seja mais profundo como uma planta que só cresce com o contato íntimo com o solo" (p. 93). Mas, além disso, o trabalho com a gravidade de Danças Passageiras traz outros fatores temporais, como a dilatação e a suspensão.

Mesmo que Danças Passageiras apresente pausas breves, a temporalidade da suspensão é trabalhada como um modo de contenção do movimento, que agrega as musculaturas, gerando uma tensão corporal específica. Nesse caso, a periodicidade de uma movimentação é interrompida, mas as ações musculares continuam sendo trabalhadas em uma dilatação que justamente acontece porque não está na ancorada na ordem da contagem, ou seja, em uma métrica regular.

A dilatação e a suspensão implicam um estudo do fluxo de movimentos. "Por exemplo: para liberar uma dada articulação, primeiro é necessário prendê-la, 
descobrir a diferença entre o que é prender e soltar" (VIANNA, 2005, p. 101). Quando Zélia elabora a sensação de suspensão temporal, valendo-se da contenção do gesto, ela apresenta um conhecimento, um domínio sobre a articulação e suas possibilidades de movimento nas potencialidades em liberar ou conter um gesto em um fluxo.

A dilatação pode ser criada com a observação perceptiva dos espaços internos do corpo. É na escuta de um trabalho corporal que percebemos os pequenos espaços internos que "passam a se manifestar por meio da dilatação. Só então esses espaços respiram" (VIANNA, 2005, p. 70).

Danças Passageiras apresenta, assim, um modo particular de criação de temporalidades. O instante, a métrica irregular, a memória e o fluxo imagético provocam os impulsos corporais de Zélia. Eles são desenvolvidos segundo uma improvisação que se desdobra pela escuta e pela atenção às informações percebidas no momento presente da cena, em ações corporais elaboradas pelas escolhas de durações, variações, repetições, lembranças e esquemas mentais imaginativos.

Todos os procedimentos temporais de Danças Passageiras são colocados em jogo na dramaturgia do trabalho. Isso porque cada escolha temporal, bem como seus agenciamentos, permitem uma organização dramatúrgica. O trabalho com a gravidade que Zélia inicia antes mesmo de entrar em cena tem qualidades específicas que permitem ritmo, projeções e dinâmicas do movimento. A criação e a combinação dessas temporalidades se dão a ver nos movimentos precisos e delicados de Zélia, assim como nas durações das transições minuciosamente exploradas em um devir que aparece em sua movimentação relacionada a uma emergência. 
3.2 Dramaturgia das instalações coreográficas: Esculturas Breves e Brevidades

Esculturas Breves (2014) e Brevidades (2016), concebidos e dirigidos pela coreógrafa, dançarina e pesquisadora de dança Helena Bastos, colaboram com o entendimento de temporalidades porque permitem observar como o processo de criação e organização de procedimentos espaçotemporais qualificam um modo de agir. As escolhas temporais desses trabalhos apresentam qualidades por meio de um agir em cooperação, elas acontecem em transversalidades por diferentes relações que possibilitam uma experiência expandida do tempo.

As temporalidades se apresentam de modos diferentes em Esculturas Breves e Brevidades. Contudo, elas manifestam questionamentos acerca dos espaços públicos da cidade e da tendência produtivista em que vivemos atualmente. Em ações que se orientam a um mover com propósito, esses trabalhos artísticos implicam uma atitude política, estética e reflexiva que chama a atenção para as responsabilidades do artista.

Esculturas Breves e Brevidades lidam com uma dramaturgia processual em uma espécie de roteiro aberto de compartilhamento de ações. Diferentemente de uma partitura fixa, dada de antemão, elas são processadas no tempo presente do acontecimento de cada experiência na cidade de São Paulo. Cada um dos trabalhos promove uma dinâmica específica na relação criada com os objetos. Essas corporalidades se constituem pela relação com a cidade, pela conexão com os objetos e pelo compartilhamento de ações entre os artistas. Tais relações se dão por arquiteturas móveis em construções provisórias na duração desses trabalhos, expandidos em praças e ruas do ambiente urbano.

Esculturas Breves foi apresentado no Largo da Batata (Pinheiros/SP) e no Vale do Anhangabaú (Centro/SP) por ações estabelecidas no tempo presente que questionam a restrição e o controle. A proposta se constitui por grandes teias tecidas por diferentes corpos entrelaçados por fitas crepes pela cidade. Essas teias permitiam uma organização mútua de fluxos e rupturas. A partir da seleção de um determinado ponto na cidade, cada um dos performers escolhe um local para ser mediado pelas fitas em conexão com os demais. Nesse início, um a um permitia ser restringido pelas fitas. Após todos estarem interligados, cada pequeno ajuste 
corporal era sentido por todos, um breve movimento e rumor afetava todos os entrelaçados, cada respiração somava nessa relação. As percepções temporais de um estar junto viabilizavam a dinâmica dessas teias, que pouco a pouco se expandiam pelo espaço urbano.

Em uma espécie de instalação coreográfica, esses acontecimentos performativos davam a ver grandes teias que interligavam os corpos, construídas por uma certa corporeidade dinâmica composta por temporalidades de escuta e de prontidão em relação ao outro, em transversalidades de diferentes informações e imprevisíveis desdobramentos de um mover em conjunto. Imagens, percepções corporais, lembranças e reconhecimentos espaciais eram a todo momento atualizados em um tempo de duração internalizado por parte de cada um dos performers. As teias são construídas na duração de uma hora em meio à atenção às restrições, necessidades e desejos das corporeidades implicadas nessa dinâmica. Ao mesmo tempo em que as ações se realizam por 60 minutos, cada integrante apresenta uma certa internalização desse tempo de duração pela própria experiência, até o momento final constituído por rupturas, rompimentos e cortes das fitas.

Em Brevidades, o plano de composição também se realiza pelas relações em diversas direções e níveis de comunicação entre os performers, entre os objetos que participam da corporeidade dos performers, entre o espaço urbano e com os passantes. O trabalho cria uma existência móvel e plástica em meio ao fluxo da cidade, com as ações compartilhadas de manipulação com bastões de madeira que transversalizam os corpos e o espaço em diversos sentidos. As arquiteturas móveis expandidas no Largo da Batata são a todo momento construídas pelos performers.

Brevidades inicia-se com uma caminhada por parte de cada performer, a partir de uma ordem sequencial previamente estabelecida. Cada um escolhe uma direção a seguir no Largo da Batata; os performers se implicam na caminhada uns dos outros, observando-os, e posteriormente utilizando os bastões, em uma atitude cuidadosa e precisa. Temporalidades de escuta, atenção e prontidão são solicitadas a cada instante, promovendo novas considerações temporais, em um atravessar o corpo do outro face às condições que ele apresenta no momento presente. Após esse ordenamento temporal de partida, o acúmulo e o peso dos bastões provocam uma corporalidade que suspende a caminhada. A exploração da gravidade - tanto a do próprio corpo quanto a dos bastões - interfere na continuidade do deslocamento, 
e exige pequenos ajustes corporais pela relação com os bastões que se incorporam ao corpo. Nessa situação, transformações singulares são pouco a pouco criadas pelos apoios provisórios de partes do corpo nos bastões. Cada um vai pouco a pouco construindo arquiteturas irreversíveis, uma vez que a sustentação desses objetos de madeira e os seus apoios vão se modificando, seja pelas quedas desses objetos, pela falta de apoio que antes promoviam ou pelo peso do próprio corpo em meio a tais materiais. Isso indica uma impossibilidade temporal de retorno das ações realizadas, até o momento final de soterramento do corpo por parte desses materiais.

A atenção, a escuta e a prontidão solicitadas tanto na interferência no corpo do outro quanto no atravessamento pelos objetos de madeira manifestam percepções temporais próprias. Além disso, as temporalidades também se apresentam pela construção de várias leituras, sem que haja uma intenção ou significação determinada nas imagens criadas. Trata-se de imagens construídas por arquiteturas que os corpos vão adquirindo à medida que são atravessados de modo contínuo pelos bastões.

A variedade das imagens é provocada pelos bastões, por diferentes corpos e pelos diversos modos de se lidar com ele. Essa variedade dá a ver arquiteturas móveis e irreversíveis no espaço. Os apoios de partes do corpo pelos bastões são a todo momento atualizados, mas o peso e a sustentação desses objetos é inevitável no decorrer dessas ações. Ao final, quedas de bastões e do corpo vão inevitavelmente acontecendo, devido ao peso e à sustentação do próprio corpo, entregas à gravidade vão sendo construídas.

Esse modo artístico de estar, se relacionar e ocupar cada espaço da cidade, além de implicar os transeuntes que intervinham nesse processo, envolvia também a claridade do dia. As experiências em fazer a ação de manhã ou no fim da tarde modificavam as relações, as imagens e as estratégias criadas. A instalação coreográfica realizada no crepúsculo do dia trazia percepções completamente diferentes tanto da performance quanto da cidade, se comparadas às ações realizadas durante a manhã. Segundo Bastos, a iluminação mais adequada para os trabalhos era no fim da tarde. "Outro desafio que surge são as chuvas, mas no final, em comum acordo, combinamos de fazer sempre, apesar das chuvas paulistanas. [...] A questão tempo é sempre uma atenção para quem trabalha na rua" (BASTOS, 2017, p. 116). 
As relações com o ambiente urbano e com os objetos cênicos não simplesmente interferem nos corpos, mas os transformam. São relações que modificam o corpo, na medida em que os materiais são incorporados e atuam como sua extensão, em ações corporais que se transformam pelos objetos e pelas informações elaboradas com o ambiente.

São experiências temporais que se organizam e se constituem por relações, uma perspectiva temporal que se estabelece e que se atualiza a todo momento, em razão do modo pelo qual diferentes informações são processadas. Relações criadas por um diálogo temporal de diferentes sentidos, seja na relação entre corpo e rua, na percepção do espectador transeunte, na conexão com os objetos e no compartilhamento das ações entre os performers. Trata-se de temporalidades implicadas em um modo transversal de relações. "A transversalidade implica, pois, um projeto concreto, talvez temporário e precário, mas com um objetivo político, enfeixando as habilidades dos agentes numa linha coletiva de ação" (BASTOS, 2017, p. 115).

Em "Brevidades" o corpo se transforma em possibilidades de breves existências. Vejo arquiteturas provisórias, sustentadas por bastões vermelhos enquanto móbiles sutis no corpo daquele que se dispõe na caminhada ser tocado por conhecidos e desconhecidos pelos bastões. Tudo no corpo deste integrante vira possibilidade de intervenção e sustentação: determinada caminhada, determinado ritmo e determinado ponto na rua. (BASTOS, 2017, p. 115)

A transversalidade implica simultaneamente o sujeito e o grupo em uma única dimensão instaurada pela própria práxis do grupo-sujeito. Ela age como suporte de desejo do grupo entre diferentes níveis de comunicação.

Segundo o autor Félix Guattari:

\begin{abstract}
A transversalidade é uma dimensão que pretende superar os dois impasses, o de uma pura verticalidade e o de uma simples horizontalidade, ela tende a se realizar quando uma comunicação máxima se efetua entre os diferentes níveis e sobretudo nos diferentes sentidos. (GUATTARI, 1985, p. 96)
\end{abstract}

Observamos, nas instalações coreográficas de Brevidades e Esculturas Breves, temporalidades plurais em uma organização coletiva, sustentada por pessoas heterogêneas em uma comunicação que se realiza por diferentes 
perspectivas. Elas se processam em uma transversalidade organizada por arranjos coletivos postos em relação não por igualdades, mas por uma atenção às diferenças desse estar junto.

Em Esculturas Breves, o estar junto se constituía por onze performers que se interligavam. As grandes teias colocavam a dinâmica resultante das percepções e conexões de cada corpo à escuta de desejos e necessidades do grupo. Um conjunto de reverberações corporais entrava nessa escuta dos onze performers: Helena Bastos, Raul Rachou, Lucas Abe, Carolina De Nadai, Beatriz Limongelli, Felipe Rocha, Marcus Garcia, Clóvis Lima, Danilo Sene, Viviane Ferreira e eu. Cada pequeno impulso de um corpo reverbera nos demais. Trata-se de impulsos corporais realizados por certas necessidades e desejos de ajustes e que enfrentavam limites face às fitas e às necessidades do outro, que intervinham nas necessidades individuais de cada um.

Em Brevidades, o convívio de criação coreográfica nos espaços da cidade se deu por sete performers: Helena Bastos, Raul Rachou, Carolina De Nadai, Danilo Sene, Felipe Rocha, Náthália Freitas e eu. Nos movíamos em grupo e em relação a provisórios atravessamentos, apoios e manipulações dos bastões, compondo as instalações móveis.

Além de observar um fator temporal implicado nas negociações com os provisórios apoios, equilíbrios e sustentações pelos ajustes corporais na ação de ceder ao peso tanto do próprio corpo quanto dos bastões, no caso de Brevidades, e fitas, no caso de Esculturas Breves, compreendemos ainda que a escuta e a atenção ao outro também apresentam um modo temporal específico de relação.

A atenção e a prontidão no estar junto imbuem uma relação de cooperação mútua, ou seja, "a capacidade de entender e mostrar-se receptivo ao outro para agir em conjunto" (SENNETT, 2012, p. 10). O estar junto implica a atenção e receptividade ao outro, ou seja, requer a cooperação, que é uma habilidade, como acontece na capacidade de escuta em uma conversa.

A proposta de estar junto tanto em Esculturas Breves quanto em Brevidades, embora seja apresentada por procedimentos espaçotemporais diferentes, enfatiza certas singularidades, como, por exemplo, como cada performer vivencia a própria queda a seu modo.

Ademais, são relações que envolvem diferentes qualidades temporais na escuta e atenção ao próprio corpo e ao outro, mobilizando mudanças corporais de 
todo o conjunto. Os fatores temporais, como a prontidão e a provisoriedade, possibilitavam também temporalidades suspensas e dilatadas, construídas por imagens e metáforas criadas de modo imprevisível, segundo o esquema corporal percebido por cada performer.

As temporalidades de escuta, prontidão e atenção promovem um mover em lentidão, pelas cuidadosas transferências de peso, pela precisão em transversalizar o corpo do outro com os bastões, pelo deslocamento calculado do corpo com a fita crepe para que os outros não caiam (embora em alguns momentos isso fosse inevitável), pelo compartilhamento de informações que reverberam em cada um dos performers. Todas essas ações requerem uma atenção dilatada e expandida que promove um mover em lentidão.

O mover em lentidão também ganha potência com a exploração da gravidade, pelas percepções do peso do corpo, pelo reconhecimento das quedas, pelas perdas de equilíbrio, pelos breves e pontuais deslocamentos, pequenas mudanças do corpo que esgarçam o tempo objetivo dos relógios.

Esse mover em lentidão estabelece um contraponto com o fluxo da cidade. $O$ fato de essas temporalidades serem processadas no espaço aberto e público, em meio ao fluxo de passantes que ocupam e vivenciam a cidade, potencializa outras relações temporais, como a imprevisibilidade e a vulnerabilidade, na medida em que não há um controle total das ações corporais dos artistas e nem da reação dos transeuntes.

Esculturas Breves e Brevidades se apresentam na fronteira entre performance e dança, se manifestam como acontecimentos performativos, em que percebemos temporalidades transversais, suspensas e irreversíveis criadas pelas e nas relações com o outro, com os objetos cênicos, com o espaço urbano e com os passantes na cidade, em uma expansão de diferentes relações.

Trata-se de procedimentos espaçotemporais não exclusivos ou restritos ao formato de um espetáculo, mas de temporalidades que agem na criação artística, pelo modo de articulação das relações. Os procedimentos espaçotemporais elaborados foram apresentados sob outras formas de criação artística, que não exclusivamente o espetáculo de dança concebido para a caixa preta do teatro. São questões temporais elaboradas por um pensamento do corpo, mas apresentadas sob outras formas de criação artística que diferem de uma organização para a apresentação de espetáculo. 
O fato de as temporalidades serem organizadas e estruturadas em um processo coerente de elaboração pelas relações com o ambiente urbano, com as ações corporais, com o outro, com os objetos e com os passantes implica um processo temporal de transformações, atualizações e imprevisibilidades.

Mesmo não sendo apresentados sob o formato de espetáculo de dança, Esculturas Breves e Brevidades apresentam duas dramaturgias baseadas em ações corporais elaboradas por artistas de diferentes corpos e de diferentes formações.

As temporalidades acontecem em Esculturas Breves e Brevidades pelo reconhecimento das múltiplas singularidades que se interseccionam em um estado de prontidão e escuta no todo, mas também na atenção às diferenças por processos de contaminação. Esculturas Breves e Brevidades se compõem pelo diálogo entre diferentes perspectivas como pensamento artístico. Esses trabalhos apresentam atravessamentos em diversos sentidos, além de uma dimensão artística e política.

Segundo o autor Jacques Rancière (2012), a atividade política não está no âmbito do poder, definido em primeiro lugar pelas leis e instituições, mas sim pelo entrelaçamento de lógicas heterogêneas. Uma dimensão política é observada na medida em que o entrelaçamento de lógicas heterogêneas não se realiza por uma hegemonia de consensos impostos, mas sim por singulares posições.

O fato de Esculturas Breves e Brevidades lidarem com escolhas espaçotemporais dilatadas e transversalizadas implica um posicionamento político, uma vez que envolve uma seleção e uma escolha articuladas de acordo com um pensamento artístico. Por exemplo, se em lugar das escolhas espaçotemporais acima descritas fossem manifestas outras escolhas, como a de um fluxo frenético de movimentos realizados em uma sequência coreográfica na cidade, o pensamento que fundamenta a dramaturgia seria completamente diferente e outras relações de sentido seriam criadas.

Esculturas Breves e Brevidades demonstram que as noções temporais criadas, selecionadas e combinadas dão a ver um pensamento artístico do corpo. Elas revelam e expõem posicionamentos, ideias e questionamentos que implicam as ações do corpo. Esses trabalhos sugerem temporalidades moventes pelas e nas relações em bifurcações políticas, artísticas e estéticas. A criação de moveres em transversalidades se estabelece pelas relações tanto entre os performers, quanto pelo fluxo de atravessamentos na e com a cidade. Com esses trabalhos, Helena sublinha a discussão entre corpo e cidade e chama a atenção para a sobrevivência 
do fazer em dança face às políticas culturais públicas, como uma responsabilidade enquanto artista.

Nesse sentido, vale apontarmos certas reflexões que disparam a criação desses trabalhos, porque, de uma certa forma, elas estão implicadas na trajetória do grupo Musicanoar - o qual Helena Bastos dirige desde 1992.

O grupo Musicanoar apresenta abordagens coreográficas contemporâneas que giram em torno de uma dramaturgia processual. Resistindo ao pensamento de um trabalho artístico como produto final, seus trabalhos se relacionam com as ações artísticas enquanto pensamentos produzidos por questionamentos e investigações que atravessam o corpo de Helena desde 1996, quando a artista ingressa na Universidade de São Paulo como professora de dança. Suas pesquisas artísticas surgem "de uma ação (mover a partir de um propósito) específica que, de algum modo, se conecta com o assunto a ser averiguado" (BASTOS, 2013, p. 41). Nesse sentido, Esculturas Breves e Brevidades propõem um pensamento coreográfico estético e político em meio a um movimento de fluxos e contrafluxos na cidade de São Paulo.

Desde 2006, época em que concebe seu espetáculo Vapor (2006), na qual Bastos e Raul Rachou apresentam uma proposição coreográfica acerca da discussão de controle e de restrição, ela vem enunciando um viés artístico, político e estético. Esse viés culmina na discussão do seu livro Corpo sem Vontade (2017), trazendo um olhar para "o qualificar a vontade de um corpo" que implica "uma responsabilidade no como eu vou trazendo determinadas ações" ${ }^{85}$ (Informação verbal).

corpo sem vontade reflete sobre um produtivismo que nos é imposto enquanto artistas e pesquisadores. Vivemos um tempo em que ideias de qualidades estão alinhadas a parâmetros quantitativos e, nesta frequência, quanto mais produzimos, o nosso status parece maior. É essa "vontade" produtivista que questiono. Para verticalizar qualquer pensamento no corpo, precisamos de tempo, e hoje nossa sociedade nos furta o tempo. Desse modo, tendemos a replicar modos de existências na urgência de demandas e não no respeito a tempos em que determinados vazios possam se instalar. Assim, corpo sem vontade não tem vontade de existir nesta tendência produtivista que vivemos hoje. Por isso, nessa ideia a questão do vazio sempre é tocada. Penso que, para transformar em outra coisa, e qualificar um determinado gesto, preciso me esvaziar, perder meu chão e permitir em deriva outras disponibilidades. (BASTOS, 2017, pp. 80-81)

\footnotetext{
${ }^{85}$ Resposta à entrevista para Tatiana. 29 de junho de 2018.
} 
Embora o enunciado "corpo sem vontade" evidencie-se na discussão entre corpo e espaço urbano proposta nos trabalhos Esculturas Breves e Brevidades, Bastos apresenta o interesse em ir para a rua para realizar criações artísticas desde 2013. Esse ímpeto é motivado por um pensamento crítico acerca da memória e do esquecimento dos espaços públicos, além do interesse em ocupar o próprio espaço público observado com as manifestações de rua, como, por exemplo, o movimento Passe Livre. Além disso, o desejo de apresentar Esculturas Breves e Brevidades no Largo da Batata também se deu por um interesse artístico, ético e político direcionado a esse espaço. O "largo sofreu um processo de higienização com a inauguração do metrô Faria Lima em 2010 [...] Isso quer dizer, toda uma cultura nordestina inserida no comércio local foi apagada. Hoje não há vestígios sobre aquelas convivências" (BASTOS, 2015, p. 85).

É nesse contexto que surge o projeto Corpos Transversos (2015), com o intuito de estudar a "relação entre corpo e cidade enquanto um fenômeno coletivo de compartilhamento de espaços por meio de constantes ajustes e acordos" (BASTOS, 2015, p. 83), projeto este que é um desdobramento de Esculturas Breves.

Brevidades também teve esse viés de compartilhamento no e com o espaço público, mas contou ainda com o desdobramento do espetáculo Deslugares (2013), em que Helena e Raul Rachou promoviam relações espaciais utilizando bastões vermelhos. Brevidades (2017) é efetivamente um desdobramento do espetáculo Deslugares (2013), no qual Helena Bastos e Raul Rachou realizam uma coreografia com um foco investigativo entre corpo e espaço, em uma plasticidade estética composta pela manipulação de bastões vermelhos que atravessam seus corpos e transversalizam o espaço em diversas diagonais, desenhando continuamente 0 espaço cênico.

Contudo, em Brevidades (2017) essa ideia ganha outra proporção, tanto por um deslocamento espacial, quanto temporal. Diferentemente da apresentação de Des/ugares, que acontecia em uma sala fechada, em Brevidades as ações são criadas em espaços abertos, expandindo as imprevisibilidades e intervenções. Depois de 5 anos de Deslugares, Brevidades apresenta outros procedimentos espaçotemporais que se desdobram, levando em conta outro ambiente e novos participantes. Embora os princípios sejam os mesmos de Des/ugares, essas novas relações modificam as organizações temporais do conjunto. 
Os espetáculos criados pelo grupo Musicanoar, como Cadeiras de Rosas (2010), Deslugares (2013), Esculturas Breves e Brevidades, são delineados também pelo interesse de Bastos em se aproximar das artes visuais, na medida em que eles apresentam o uso de objetos em conexão com os corpos para criar espacialidades.

Diferentemente dos espetáculos concebidos por Bastos apresentados em espaços fechados, como teatros e galerias, os trabalhos Esculturas Breves e Brevidades assumem outros riscos, como o deslocamento espacial que se expande na e para a rua, novas estratégias temporais de compartilhamentos com mais pessoas e um lançar-se em acontecimentos performativos.

O fato de Helena convidar mais pessoas para participarem dessas duas criações, que pela primeira vez se lançam no estar junto, também foi um desafio, porque Bastos trabalha desde 1992 com parcerias sólidas e frequentes. O nome Musicanoar

surge da ideia de que o movimento, assim como a música, dissipa-se no ar após sua execução, sendo que a friç̧ão por ele produzida gera ruídos, ou seja, música no ar. O Musicanoar nasceu da parceria entre Helena Bastos e o músico Rogério Costa. (BASTOS, 2013, p. 15)

Além dele, a parceria duradoura com Raul Rachou faz parte da conduta investigativa dos 25 anos do grupo.

Brevidades e Esculturas Breves apresentam um viés artístico-político, sob outras formas de dança, por instalações coreográficas que lidam com o tempo e o espaço em que vivemos. Trabalhos que exploram qualidades temporais como a escuta, a prontidão, a atenção ao próprio corpo e ao outro como estratégias de compartilhamentos; temporalidades dilatadas pela percepção da gravidade, em deixar ceder o peso do corpo e pelo mover em lentidão pelos pequenos ajustes de todo o conjunto, em uma experiência de cooperação. Eles envolvem a percepção de necessidades, angústias, restrições, desejos, apoios, transferências e até mesmo o reverberar a respiração do outro. Isso porque o eco de um provoca um deslocamento tanto espacial quanto temporal do outro, cada movimento transforma o movimento do outro. Diferentes percepções corporais da cidade num estar juntos, no tempo presente da cena, por diálogos corporais sutis realizados por temporalidades heterogêneas, de modo transversal, por relações que valorizam as diferenças e acontecem em múltiplas direções e sentidos, em um fluxo de transições sutis de movimentos que modificam o corpo e a rua de maneira simultânea. 


\subsection{Dramaturgia de Nó(s) de temporalidades}

Certas temporalidades construíram o processo de criação de Nó(s), do qual participei como coreógrafa e dançarina. O ponto de partida para esta criação foi pensar procedimentos temporais implicados no movimento para o compartilhamento com o outro e a forma como eles poderiam promover dinâmicas e ritmos em uma dança.

Em linhas gerais, a coreografia é realizada por mim e pelo ator Pablo Perosa. Ela explora diferentes modos de relações entre um homem e uma mulher através de diálogos corporais de entrelaçamentos e desentrelaçamentos, encontros e desencontros, dissensos e consensos, proximidades e distanciamentos. A estrutura acontece por três diferentes nós construídos pelos parâmetros temporais, tais como o fluxo, a defasagem, o uníssono, a gravidade, a repetição e a simultaneidade na composição das ações, permeados pelas noções e questões temporais do trabalho.

Além das temporalidades compostas pelo dueto, as parcerias com o músico Marcelo Castilha, com a vídeo-artista Elisa Damázio, com o fotógrafo Edson Kumasaka, com o iluminador Vinícius Andrade e colaborações artísticas da coreógrafa Helena Bastos, do professor e pesquisador de dança Vagner Rodrigues e do dançarino Petterson Costa, expandiram os procedimentos temporais no processo de criação.

A dramaturgia se deu por um processo coletivo no qual cada um desses artistas trouxe diversas referências sobre as questões temporais e o modo como elas eram agenciadas na composição, com aulas, aporte de livros, músicas, filmes, troca de ideias e pontos de vista. Estabelecemos, com esses artistas, de experiências diferentes e que buscaram estar juntos em uma mesma temporalidade, uma residência de criação que acontecia três vezes por semana, no Centro Comunitário da Vila Madalena, em São Paulo, durante novembro de 2015 a maio de 2016, o que permitiu um diálogo entre variados modos de pensar o tempo em diferentes campos do conhecimento para uma construção cênica.

Os artistas desse processo, que traziam conhecimentos artísticos advindos de outras linguagens, também trouxeram diversas referências temporais no processo de criação. Partir de questões temporais para a criação abre um leque 
infinito de possibilidades, porque as noções temporais estão em tudo, mas considero que é a consciência de como elas surgem em um processo de criação que desdobra e qualifica temporalidades em uma criação artística.

No início do processo, lembro-me de longas conversas sobre a sequência de Fibonacci com o músico Marcelo Castilha, conversas sobre o amor e a saudade com a artista multimídia Elisa Damázio e da discussão com o ator Pablo Perosa sobre as qualidades da rapidez, leveza e multiplicidade abordadas no ínicio da pesquisa com a inspiração da obra literária Seis propostas para o próximo milênio, do escritor italiano Ítalo Calvino.

$\mathrm{Na}$ conversa com o fotógrafo Edson Kumasaka sobre temporalidades, ele sugeriu o título do espetáculo, bem como a grafia: NÓ(S). Nome que se refere ao nó de uma ação. O verbete nó indica questão delicada, teorema, capítulo, momento, contratempo, peso, sentido e resistência, segundo o Dicionário Analógico da Língua Portuguesa (2010); ao mesmo tempo, a palavra nó(s) também indica a primeira pessoa do plural.

Certas questões surgiram no processo, como, por exemplo: que noções temporais emergiam da coreografia? Como elas poderiam promover um diálogo entre os dois corpos? Como elas poderiam estar articuladas na construção do espetáculo como um todo de modo dinâmico? Como apresentar diferenças de procedimentos temporais? Qual seria a melhor estrutura em termos de ínicio, meio e fim na duração do trabalho e por quê?

As noções temporais eram construídas pouco a pouco durante o processo de elaboração e de reflexão, de acordo com as diversas referências temporais que chegavam à criação. Mas eram as ações geradas, dependentes das espacialidades e temporalidades, que possibilitavam o desdobramento e o reconhecimento das temporalidades.

As questões e noções temporais estão entremeadas às ações corporais e foram exploradas no processo de composição em três capítulos, três momentos distintos de acordo com os procedimentos temporais investigados. Descrevemos cada um deles abaixo, considerando que as temporalidades se apresentam pelos corpos que as dançam, pelos modos de relações construídos pelos procedimentos temporais combinados em cada cena e pela seleção de um conjunto de parâmetros temporais trabalhados. 


\section{Primeira cena:}

A primeira cena explora temporalidades com o outro realizadas pelo engajamento ativo e passivo na manipulação entre os dois corpos. As temporalidades deste momento se baseiam no toque, em estar atento à percepção do outro e nos espaços criados com os entrelaçamentos do dueto. O dueto propõe um diálogo de mudanças simultâneas por um tipo de entrelaçamento articular que necessita de uma escuta permanente entre os dois corpos, os movimentos vão sendo criados de modo ativo-passivo e por uma economia de engajamento muscular. Em vez de um líder, os entrelaçamentos corporais requerem um comum acordo de manipulações, realizadas tanto pela percepção da pele, quanto por direcionamentos de fluxo induzidos ao outro pela manipulação e pelo movimento espiral.

Os entrelaçamentos partem da pergunta: quais são as temporalidades que o outro me apresenta e como me relaciono com elas no tempo presente da cena? Tais entrelaçamentos lidam com uma atenção contínua aos equilíbrios e desequilíbrios gerados pelo movimento do outro, aos engates criados, aos espaços reduzidos entre um corpo e outro, ao fluxo que se gera, ao reconhecimento das inspirações e expirações de ambos, às pausas, que permitem acomodar e ser acomodado por partes do corpo do outro. Em suma, trata-se de estar atento ao tempo presente, sem antecipações futuras.

Os entrelaçamentos corporais e as conduções de movimento em espiral foram construídos pelo dueto a partir de princípios de certos golpes do Aikido, orientados pelo dançarino Petterson Costa, e de passos do Tango, trabalhados com o professor Vagner Rodrigues. Após este estudo, realizado através de aulas, o processo de criação se deu pela improvisação de conduções e manipulações que partiram destas práticas. Foi um processo que se deu pela improvisação, a partir da qual notamos a dificuldade de repetir certos encaixes que eram desencadeados pelo fluxo. A percepção dessa dificuldade nos levou a um trabalho de repetição dos movimentos levantados na improvisação - iniciamos um processo de repetição das transições que possibilitavam os encaixes entre os corpos. A memória dos fluxos de cada trajeto de movimento feito por ambos era sistematicamente requerida, para que os nós de entrelaçamentos pudessem ser processados por nossos corpos. A dificuldade neste momento era não colapsar, em razão dos intervalos tão estreitos 
entre os corpos, mas sim permitir um breve espaço com o intuito de gerar um fluxo de ações e de continuidades de entrelaçamentos e desentrelaçamentos articulares. Isso requeria uma escuta e uma atenção permanentes, principalmente nas transições que permitiam formas determinadas de dobras e encaixes.

Esses entrelaçamentos traziam para mim a imagem de grandes árvores que, com seus galhos, se enlaçam em outros galhos e em outras árvores. Elisa e Marcelo trabalharam com essa mesma imagem na construção do vídeo. Eles exploraram, na primeira cena, imagens do céu e de entrelaçamentos entre árvores observados e captados por Elisa, além da captura de imagens de entrelaçamentos de fios urbanos na paisagem do céu, observados por Marcelo.

A coreografia desse primeiro momento explora a lentidão entre nós que favorece micropercerpções e conexões através da escuta ativa, do toque, da respiração, do apoio e do peso do outro, bem como a resistência ou a entrega ao se deixar levar e conduzir. Depois, os mesmos entrelaçamentos acontecem da maneira mais veloz possível, com mudanças espaciais e de direções que modificam a qualidade do toque, das manipulações, das transições e dos movimentos criados anteriormente.

A relação com o outro implica um fator temporal na medida em que é capaz de me transformar, porque a temporalidade do outro pode trazer mudanças. Isso também envolve o espectador, "como uma relação complexa capaz de me temporalizar, um enfoque específico da relação com o outro que diz respeito a uma situação precisamente definida como um face a face [...] corporal na realização mesma do tempo"86 (FONTAINE, 2004, p. 45).

A temporalidade junto do outro implica uma atitude face ao estar presente com esse outro, uma responsabilidade latente no estar juntos, onde aparecem também conflitos, discordâncias e dissensos. Isso porque, longe de uma indiferença em relação ao outro ou de uma igualdade de pensamentos, trata-se de construções justamente feitas pela exposição das diferenças perceptivas entre nós. Diferenças também sentidas a cada ensaio. Por exemplo, num dia, os entrelaçamentos eram feitos de modo amoroso, mas, em um outro dia, pareciam duros e bruscos. Já em

\footnotetext{
${ }^{86}$ Trad. nossa a partir do original : "Emmanuel Levinas s'intéresse à une donnée du temps dont la validité me semble particulièrement efficiente en ce qui concerne le spectacle de danse. Dans Le Temps et L'Autre, il explique que 'la situation de face-à-face serait l'accomplissement même du temps' [...] II aurait un enjeu spécifique de la relation à autrui au regard du temps, dans cette situation précisement définie comme face-à-face."
} 
outro, os vínculos eram suaves e fluídos. Tudo depende de como cada um se colocava presente e da conexão anteriormente criada: micropercepções qualitativas modificam o corpo.

\section{Segunda cena:}

$\mathrm{Na}$ segunda cena, uma temporalidade elástica é desenvolvida pelo movimento relacional, que ativa micropercepções nas transições, nas tensões e distensões dos movimentos mediados por uma corda elástica. Micropercepções são percebidas em cada transição, em cada mudança de direção ou de transferências de níveis de um e de outro corpo. Nessa cena, os equilíbrios e desequilíbrios são intensificados pela percepção de cada puxada, rebote ou distensão da corda, que nos faz questionar: qual a medida necessária para um equilíbrio dinâmico?

A corda elástica que une os dois corpos pela cintura foi explorada depois de muitos ensaios por diferentes tipos de elástico, até encontrarmos o material que possibilitaria os engates seguros necessários. O processo triangular construído pelos dois corpos e pela corda permitia um movimento relacional, num jogo com a gravidade em que quedas, suspensões, apoios e equilíbrios eram realizados pelos corpos e mediados pela elasticidade da corda. A relação a partir da qual nos movíamos era constantemente reformulada, porque as transições não eram estáveis, se realizavam pelas tensões e distensões provocadas pela flutuação da corda e das ações entre os dois corpos.

O processo triangular realizado pelos dois corpos mediados pela corda elástica produz uma elasticidade temporal de uma linha ativa de constantes reformulações que mobilizam um mover em relação. É com essa elasticidade do movimento relacional que vamos conhecendo a forma como nos mover. "Sentir a elasticidade é sempre saber que estamos na borda" (MANNING, 2009, p. 118), ou seja, na extremidade, no limite da propulsão da força elástica que pode estar presente tanto em seu alongamento, quanto na sua contração, trazendo um novo movimento.

Segundo a autora Erin Manning ${ }^{87}$ (2009), "o intervalo criado pelo movimento relacional é plano de composição no qual o movimento envolve dobras de todo o

\footnotetext{
${ }^{87}$ Erin Manning é pesquisadora e professora em Arte Relacional e Filosofia da Faculdade de Belas Artes da Universidade de Corcordia (Montreal, Canada).
} 
seu potencial de passados e futuros" ${ }^{\prime 88}$ (p. 115). O movimento relacional significa mover a relação. Quando isso acontece, uma intensidade é criada, não necessariamente quando uma pessoa se move, mas quando a intensidade do movimento pode ser sentida pelo movimento com o outro. A "elasticidade da relação é perceptível em sua margem afetiva, na emergência do irreconhecível onde, o que se conhece, se estende e contrai em uma propulsão da experiência" (MANNING, 2009).

Em Nó(s), o movimento relacional é mediado por uma elasticidade entre as ações dos dois corpos e da corda elástica, em uma força triangular que gera reformulações qualitativas de percepções ativas nos movimentos e principalmente nas transições.

A elasticidade está associada ao campo das curvaturas que quase inflexionam o próximo equilíbrio, o próximo eixo, o próximo movimento, mas não completamente: esse quase se refere ao movimento que ainda não chegou. Ou seja, "a elasticidade do quase é parte da curva" (MANNING, 2009, p. 114), uma elasticidade na qual o que se experimenta é a sensação rítmica do movimento e sua atualização (MANNING, p. 115).

A ideia de Manning de que o ponto elástico é cheio de acontecimentos encontra ressonância quando observo o processo de criação de Nó(s). De acordo com ela, "o ponto elástico é um nó em movimento ao longo de uma linha flutuante que não tem começo nem fim" ${ }^{89}$ (MANNING, 2009, p. 114). As constantes percepções das variações de equidistância da corda, bem como sua tensão e distensão, também são movimentos.

Quando a corda elástica atinge seu limite máximo de extensão, a elasticidade do quase é percebida por nós como emergência de um movimento. Essa percepção teve colaboração do feedback de Helena Bastos. Ela ajudou a percebermos o desenvolvimento da cena, trabalhando com as curvaturas da corda e sua relação com a movimentação, ao experimentarmos gradualmente a tensão da corda.

A curvatura da corda vai se estendendo e tensionando, tal como acontece com as extensões dos movimentos. A tensão da corda é trabalhada por nuances de

\footnotetext{
${ }^{88}$ Trad. nossa a partir do original: "The interval created by relational movement is the plane of consistency of this circumvolution, elasticity the plane of composition. [...] In the elastic moment, the movement becomes more-than, enveloping in its folds all of the potential of its pastness and its futurity." (p. 115).

${ }^{89}$ Tradução nossa a partir do original: "The elastic point is a travelling node along a fluctuating line that has no beginning nor end".
} 
distensão para que pontos de inflexões e variações possam ocorrer. Ou seja, a inflexão da corda possibilita uma linha ativa de dinâmicas de ações entre os dois corpos. Quando a corda atinge sua extensão máxima, acontece uma tensão e uma busca por equilíbrio que começa a tomar outra forma também nos movimentos dos corpos. Por exemplo, em um dos momentos da cena, a força triangular provocada pelos dois corpos e pela corda em sua máxima elasticidade possibilitava um contrapeso de forças. A partir disso, Pablo e eu sugerimos a imagem na qual estávamos sentados em uma longa mesa de jantar. Nesse momento, pareceu haver uma suspensão onde algo podia acontecer. O próximo movimento ainda não havia chegado, mas esse momento de contrapesos sugere diálogo entre nós.

A ideia de trabalhar com uma corda elástica surgiu com diversas referências sobre tempo. Por exemplo, em uma conversa sobre questões temporais, logo no início da criação, Pablo Perosa sugeriu que assistíssemos ao filme Dolls, título original, Dooruzu, lançado em 2002, do diretor japonês Takeshi Kitano. De modo sucinto, o filme trata de questões temporais, embaralhando três temporalidades diferentes em três histórias criadas por dois personagens que estão condenados a viver amarrados um ao outro por uma corda. Esse filme foi uma das inspirações para que Nó(s) trabalhássemos com uma corda elástica e para todo o desenvolvimento da segunda cena do trabalho. O uso da corda elástica também foi inspirado pela prática de performance urbana ministrada pelo diretor teatral e professor Antônio Araújo, na disciplina "Práticas Site Specific e de Performance Urbana" do Programa de Pós-Graduação da ECA/USP que cursei ao longo de meu doutorado. Nessa disciplina, realizamos derivas na cidade de São Paulo envoltos por um elástico, a partir do qual um grupo de performers deveria se deslocar, assumindo as direções espaciais de forma conjunta. A experiência aconteceu no bairro da Bela Vista.

Outra referência que nos levou a trabalhar com uma corda foi uma das cenas do filme Pina (2009), do diretor Wim Wenders, na qual há apenas uma mulher, a dançarina Tsai-Chin Yu. Em um movimento de vai-e-vem, ela constantemente corre, mas é puxada por uma corda presa a um suporte que fica preso na coxia. Essa cena faz parte da peça Como el musguito en la piedra, ay si, si..., último espetáculo da coreógrafa Pina Bausch.

Todas essas referências possibilitaram a exploração de uma temporalidade elástica em Nó(s), que faz mover em espiral os dois corpos, em um jogo dinâmico provocado pelo movimento relacional. Quando, ao final da cena, acontece o 
encurtamento da corda, provocado pelo emaranhamento do material pelos corpos do dueto, a elasticidade da relação é contraída pela tensão da corda e pela diminuição dos espaços entre os corpos. Isso traz imobilidades e provoca um diálogo de curtos movimentos em um espaço reduzido. A elasticidade das relações no final dessa cena é encurtada, bem como todo o desdobramento de uma gama de variações, quando já não há mais espaços entre nós e outras possibilidades de se relacionar acontecem por micromobilidades, até o desfecho da cena.

\section{Terceira cena}

$\mathrm{Na}$ terceira cena, um jogo entre o uníssono, a defasagem e a repetição permite o diálogo desse momento entre o dueto. Trabalhamos com um outro modo de nos relacionarmos. A relação temporal é aqui guiada pelo uníssono, no qual compartilhamos uma mesma sequência de movimentos de forma simultânea, traçando um mesmo trajeto no espaçotempo da cena. É com esse uníssono que damos a ver outro procedimento temporal, o da defasagem. Esses fatores temporais são orientados pela questão: quais os ritmos de Nó(s)?

A defasagem indica ajuste, deslocamento de tempo ou de espaço, alterações de estrutura, mudança de trajetória, lacuna, falha. Isso não quer dizer que a defasagem opere por uma pausa, mas sim por outra modulação de ritmo que não necessariamente é regular.

A defasagem se configura como um intervalo perceptivo, uma adaptação na qual o corpo se implica em seu meio. Nesse sentido, todos nós estamos em defasagens em relação ao outro. O autor Gilbert Simondon (2008) observa a defasagem a partir de uma constância que assegura a apreensão dos objetos e que coloca em jogo uma atividade de antecipação, "permitindo a identificação de um objeto, [...] permitindo prever as transformações dos sinais recebidos em função do entorno e da ação em curso"90 (SIMONDON, p. 77). O autor nos dá um exemplo de defasagem quando vimos um avião no céu. Visualmente,

o avião está à frente do ponto de onde vem o som, porque o som que chega nesse momento é aquele que foi emitido pelo avião um ou dois segundos mais cedo [..] a imagem intra-perceptiva do avião leva

\footnotetext{
${ }^{90}$ Trad. nossa a partir do original: "La constance au sens haituel du terme est un cas particulier de l'activité d'anticipation à court terme permettant l'identification de l'objet et la réception permanente des signaux permettant de le suivre; [...] (une formule de potentialité permettant de prévoir les transformations des signaux reçus en fonction de l'entourage et de l'action en cours)".
} 
em conta a defasagem entre a localização sonora e a localização visual. ${ }^{91}$ (SIMONDON, 2008, p. 77)

A defasagem entre o que é visto e o que é escutado está implicada em uma modulação da constância.

A defasagem aparece na coreografia do espetáculo Nó(s) como um situar-se de uma outra maneira, apresentando breves desvios dos procedimentos temporais iniciais no fazer conjunto no tempoespaço da cena. Com o uníssono, nós compartilhamos simultaneamente uma mesma movimentação proposta nesta cena, bem como as durações e os caminhos a serem feitos, e instantes de defasagens dialogam com esse uníssono por certas graduações rítmicas que surgem entre nós.

No decorrer dos ensaios, utilizamos um metrônomo para marcar o tempo de cada movimento de ambos. Posteriormente, começamos a afinar temporalmente nossos movimentos sem a ajuda desse objeto exterior, valendo-nos somente da temporalidade da escuta, atenção e prontidão de nossos próprios movimentos e da escuta dos sons de nossos passos pelo chão. A constância desse fazer permitiu identificações, apreensões temporais e um determinado ritmo entre nós.

A experiência rítmica foi realizada por uma constância do uníssono de uma sequência coreográfica e pelas emergentes defasagens. A sequência foi feita de modo simultâneo por movimentos simples de avançar e retroceder, que se desdobram em outra sequência, conforme os deslocamentos vão acontecendo. Concomitantemente à coreografia, há projeções em vídeo que configuram o uníssono e a defasagem com mais dois corpos projetados de forma simultânea a nossos corpos e movimentos.

Quando a coreografia entre os quatro corpos se desdobra, temporalidades em defasagens começam a intervir entre o real (os dois corpos em cena) e o virtual (as imagens projetadas). A defasagem aparece no trabalho entre graduações de velocidades nos deslocamentos espaçotemporais. Ela se multiplica em três camadas da cena: na primeira, os dois corpos, na segunda, as sombras desses corpos, e, na terceira, a imagem em negativo de mais dois corpos. Em cena, seis corpos se apresentam em uníssono, simultaneidades e defasagens.

\footnotetext{
${ }^{91}$ Trad. nossa a partir do original: "visuellement l'avion est en avant du point d'où provient le son, parce que le son qui arrive en ce moment-ci est celui qui a été émis par l'avion une ou deux secondes plus tôt; au bout de quelques essais, l'anticipatin est réadaptée, quand on entend le son d'un avion à réaction au-dessus de la tête, on cherche à le voir plus loin; l'image intra-perceptive de l'avion à réaction tient compte du décalage entre la localisation sonore et la localisation visuelle".
} 
O trabalho Fase, da coreógrafa Anne Teresa de Keersmaeker, que abordaremos no capítulo posterior, nos inspirou para essa cena. Porém, diferentemente de trabalharmos o uníssono implicado no tempo musical, o que orienta o uníssono do espetáculo Nó(s) é o compartilhamento de uma temporalidade de escuta contínua de certos movimentos feitos ao mesmo tempo, em um compartilhamento de espaços e durações de forma simultânea, permitindo que as defasagens façam parte desse diálogo. Em um fluxo, em suma, que possibilita um ritmo provocado pelos dois corpos por uma atenção ativa no espaço.

O fluxo é um parâmetro temporal do movimento relevante para essa cena. Aqui ele possibilita a sensação de autonomia e liberdade, contrapondo as qualidades temporais de restrição, tensão e suspensão provocadas na cena anterior com a exploração da corda. O fluxo aparece desde o início da cena por um continuum dos movimentos de uma sequência que se desdobra, uma modulação temporal de tônus e energia, que acontece num primeiro momento de forma lenta e, posteriormente, em velocidade acelerada pelos movimentos.

Para o fluxo, a imagem da formação e rebentação das ondas do mar que sobem de forma lenta e explodem em rapidez em seu declínio colabora na analogia do lento e do rápido como um fluxo de energia.

O fluxo, o uníssono, a simultaneidade, a repetição, a gravidade, a escuta, as tensões e distensões provocadas pelo processo triangular entre os dois corpos e a corda, bem como os entrelaçamentos articulares da primeira cena, se configuram como os procedimentos temporais realizados na composição. Ao trabalhar com esses procedimentos, novas questões temporais surgem no processo de criação.

Mas esses elementos temporais dependem do modo como são trabalhados e articulados com outros elementos que intervêm no processo. Escolher um procedimento temporal para a criação acaba por envolver outro, são temporalidades que grudam uma à outra: elas não se dão sozinhas porque formam um conjunto de escolhas temporais que possibilitarão um determinado modo de organização.

Nesse sentido, as relações temporais também podem ser processadas, por exemplo, em solos de dança, porque as temporalidades sempre se realizarão por um processo relacional. Todo procedimento temporal criado é uma combinação de diferentes parâmetros e noções temporais. 
Contudo, no espetáculo Nó(s), as temporalidades se processam em relação também a um parceiro de cena. E lidar com temporalidades em relação ao outro implica trabalhar as diferenças.

A partir de junho de 2016, o espetáculo teve circulação, sendo apresentado em diversas cidades: São Carlos, São Bernardo do Campo, São José dos Campos, Jundiaí, Vinhedo, Praia Grande, Ribeirão Preto, Bauru, Botucatu, Diadema e Araras. Apresentamo-nos em diversos teatros municipais, que, em sua maioria, têm a característica de contar com palcos grandes, mas também nos apresentamos em centros culturais, onde o palco era pequeno. Embora o espetáculo acontecesse melhor em espaços maiores, isso provocou a reflexão de como as temporalidades criadas no espetáculo se modificavam em cada lugar, porque cada um deles foi acompanhado de adaptações espaciais, que modificavam os tempos da coreografia.

A dimensão dos espaços cênicos alterava as temporalidades na medida em que o tamanho dos palcos modificava a duração das ações; o tamanho da corda também sofria alterações dependendo do espaço físico, as tensões dos diferentes tamanhos de cordas, utilizadas para cada dimensão de área cênica, influíam na relação e nos movimentos; os trajetos em uníssono da última cena precisavam igualmente ser revistos a cada lugar de apresentação. As reações do público influenciavam a percepção do dueto; os lugares modificavam a duração do ritmo de cada ação em contato com o outro, se esta se prolongava ou não. Em suma, cada espaço modificava consideravelmente as temporalidades trabalhadas no processo.

Embora o roteiro de ações fosse fechado e definido antes das apresentações, as temporalidades eram atualizadas na dramaturgia a cada apresentação, também em razão de que os espectadores de cada um desses lugares traziam retornos variados, que, por sua vez, transformavam nossas intenções para as apresentações seguintes.

As temporalidades elaboradas na criação não se fixam no momento dessa criação, elas são atualizadas na apresentação pelas pessoas que a assistem, pelos espaços físicos e suas atmosferas e pelos contextos e situações que precedem a própria apresentação.

Mesmo que os procedimentos sejam determinados de antemão ou incorporados no período dos ensaios, há diversas variáveis que atualizam esses procedimentos a cada apresentação. Se as temporalidades viabilizam uma dramaturgia, elas não são fixas, porque os procedimentos temporais estão em 
contínuo processo de atualização pelas novas informações que irão surgir nas relações com o espaço e com o espectador.

São procedimentos temporais que irão sofrer modificações porque se deslocam. Uma estrutura cênica, elaborada para o compartilhamento com o espectador, com o intuito de comunicar um pensamento artístico, não para no tempo, porque o pensamento não para; ou seja, são temporalidades provisórias que serão atualizadas na experiência do fazer.

A criação e a combinação de procedimentos espaçotemporais de um trabalho determinam um modo de organização, construção e combinação de temporalidades, em escolhas feitas em detrimento de outras, de acordo com um pensamento artístico. Criar, observar e ter consciência dos procedimentos temporais trabalhados em um processo artístico sem dúvida disparam criações e põem em curso uma dramaturgia. A consciência das escolhas temporais abre espaço para a criação e desdobramentos cênicos. Se a dramaturgia é processual é porque ela está ligada às temporalidades. 


\section{Parâmetros temporais na composição de procedimentos}

4.1 Parâmetros temporais do movimento

Os parâmetros temporais do movimento compõem uma das facetas de temporalidades em dança. De acordo com Fontaine (2017), “a temporalidade é plena de níveis e os parâmetros temporais do movimento correspondem a um aspecto de temporalidades" (Informação verbal). ${ }^{92}$ Segundo ela, não podemos limitar temporalidades apenas como parâmetros do movimento, porque esses parâmetros compõem um dos aspectos de temporalidades na concepção de um pensamento artístico, e há outros elementos que entram em jogo com o movimento dançado.

$\mathrm{Se}$ as temporalidades correspondem aos procedimentos temporais elaborados em uma concepção cênica em sua totalidade, restringi-las ao movimento dançado limitaria sua complexidade, porque a criação de dados temporais assume diversos aspectos na concepção global de uma dramaturgia, como abordamos no capítulo anterior.

Com essa compreensão, a pesquisa seleciona o fluxo, a gravidade, o uníssono, a repetição, a velocidade e a memória como alguns dos "parâmetros temporais do movimento" 93 para a reflexão. Abordamos, nesse capítulo, como cada um deles apresenta especificidades, revela estratégias de criação em dança e varia de acordo com os procedimentos temporais criados em cada coreografia.

Cada criação lida com os parâmetros temporais do movimento de acordo com os procedimentos elaborados num processo, conforme o modo como cada parâmetro será articulado. Por exemplo, vimos que o fluxo se processa de modo

\footnotetext{
92 Entrevista a Tatiana Melitello, realizada com o estágio na França no período de agosto de 2017 a maio de 2018.

${ }^{93} \mathrm{O}$ entendimento de que o fluxo, a gravidade, o uníssono, a repetição, a velocidade e a memória são parâmetros temporais do movimento se desdobrou no laboratório de dança realizado na Universidade de Bordeaux Montaigne, a partir das conversas com a autora e pesquisadora em dança Geisha Fontaine, no período de agosto de 2017 a maio de 2018.
} 
diferente nos três trabalhos abordados no capítulo anterior, bem como a gravidade e a velocidade.

Nesse momento, realizamos uma reflexão acerca de cada um dos parâmetros, observando como eles, além de apresentarem características próprias, são recorrentes em dança. Esse estudo é realizado com a percepção de que eles se tornam relevantes em certas obras coreográficas e com a observação de como sofrem variáveis. Como, por exemplo, o uníssono na obra Tempo 76, dirigido pela coreógrafa francesa Mathilde Monnier e o uníssono na obra Fase: quatro movimentos para a música de Steve Reich, concebido pela coreógrafa belga Anne Teresa de Keersmaeker; o fluxo percebido na obra So Blue, da coreógrafa canadanse Louise Lecavalier e a gravidade subvertida com a obra Men Walking Down on the Side of a Building, da coreógrafa norte-americana Trisha Brown. A escolha dos parâmetros temporais do movimento é abordada no presente estudo com exemplos de obras coreográficas. Eles são observados com a percepção de que tais parâmetros se destacam nas obras citadas, com o intuito de observar como se apresentam de diferentes modos de acordo com um pensamento coreográfico.

O fluxo, a gravidade, a memória, a repetição, a velocidade e o uníssono implicam nuances temporais elaboradas pelo movimento do corpo. Não existe dança que não trabalhe com a gravidade, porque ela atua no corpo a todo momento, mesmo quando estamos de pé ou em uma meia ponta; toda dança articula um certo fluxo, mesmo um corpo parado. O que queremos dizer é que se trata de elementos frequentemente explorados em dança.

Ou seja, são parâmetros temporais do movimento que correspondem a um aspecto de temporalidades e que compõem uma dramaturgia das ações do corpo. Trata-se de parâmetros temporais do movimento que, dependendo do modo como são trabalhados, viabilizam um pensamento artístico, ao tecer as lógicas e coerências de uma proposição cênica pelo próprio movimento dançado. Mesmo compreendendo que a dramaturgia das ações do corpo frequentemente é articulada com outros elementos de uma concepção artística, tais como a música, a iluminação, por vezes palavras e objetos, buscamos focar aqui certos parâmetros temporais implicados no movimento.

Contudo, os parâmetros temporais do movimento não existem em si. É o seu conjunto que possibilitará uma dança, são parâmetros que apenas existem em relação com outros, ou seja, é a sua combinação que viabilizará essa dança. 
As diversas qualidades temporais dependem de como são performadas pelo corpo, de como são geradas pelo movimento. Na medida em que esse processo é alimentado por novas relações durante a criação, essas qualidades geram outras que se desdobram e se especificam. Trata-se de parâmetros temporais do movimento que portam singularidades, são articulados em cada obra de acordo com questionamentos de cada processo. Eles são qualificados e ressignificados de acordo com cada proposição artística.

Com essa compreensão, esse capítulo busca realizar um diálogo entre os parâmetros temporais percebidos nas obras coreográficas e a reflexão acerca de cada parâmetro proposta por certos autores. Buscamos traçar uma conversa, por exemplo, com o fluxo percebido pelo pesquisador André Lepecki e o fluxo percebido pela coreógrafa Louise Lecavalier, ou seja, um diálogo entre as obras observadas e o pensamento de certos pesquisadores acerca dos parâmetros selecionados na presente pesquisa.

Os parâmetros temporais do movimento apresentam diversos questionamentos. Na medida em que variam de "valores" ao longo da história da dança, eles correspondem a um aspecto de temporalidades que também envolvem pensamentos artísticos e políticos, que aprofundaremos no próximo capítulo. Contudo, as temporalidades apresentam infinitos modos temporais qualitativos criados, porque elas abrem espaço para infinitas qualidades que cada coreógrafo ou dramaturgista agrega em suas obras, a depender do próprio processo de feitura de um trabalho de criação. Cada um dos parâmetros temporais do movimento se manifesta de acordo com cada processo. E, mesmo em uma só obra, cada parâmetro do movimento pode se desdobrar de diferentes modos. Observamos que eles portam certas especificidades, ao se constituírem pelas ações corporais e apenas se concretizarem de maneira relacional a cada processo, mas, ao mesmo tempo, apresentam características singulares a cada parâmetro. 


\subsection{A Gravidade e a obra Men Walking Down on the Side of a Building}

Embora poucos autores relacionem a gravidade ao tempo, ela implica um fator temporal qualitativo e singular do movimento dançado. O trabalho sobre a gravidade promove uma atitude atenta ao presente sensório-motor do corpo. A exploração deste parâmetro produz novas considerações temporais que modificam o corpo e seu movimento.

A gravidade está presente na gestão de apoios, equilíbrios, desequilíbrios, nas organizações e transferências de peso, tanto do corpo inteiro, quanto de suas pequenas partes. Ela se realiza pela ação gravitacional na propriocepção dos movimentos do corpo, requer uma escuta do próprio corpo e do seu entorno, além de uma prontidão e atenção ao seu estado presente.

O parâmetro temporal da gravidade envolve as ações corporais na percepção dos ajustes e reajustes do corpo aqui e agora, no momento presente também das transições e de suas constantes atualizações.

A filósofa e pesquisadora em dança Marie Bardet ${ }^{94}$ (2012) ajuda a compreender a gravidade como um fator temporal do movimento. Segundo ela, as temporalidades são promovidas pelos ajustes gravitacionais que partem do movimento do corpo. "Tomada através da experiência da diferenciação gravitacional, a dança se efetua por um descentramento, nas temporalidades que ali se tecem" 95 (BARDET, p. 231). As renegociações dos apoios gravitacionais de cada movimento permitem qualidades e intensidades, em um descentramento temporal, transversal e contínuo de uma duração que constantemente se transforma na intersecção sensório-motriz. Ela nos traz uma ideia de temporalidade que se efetua no fazer do movimento, em um "presente da composição, percebido de maneira singular pela ação gravitacional, através da propriocepção dos movimentos de meu corpo no espaço"96 (BARDET, 2012, p. 215).

\footnotetext{
${ }^{94}$ Marie Bardet é doutora em estética e filosofia contemporânea e professora de dança da Universidade Paris 8.

${ }^{95}$ Tradução nossa a partir do original: "Tomada a través del atravesamiento de la experiencia de la diferenciación gravitatoria, la danza (se) efectúa por un descentramiento en el sentido de la logitud, en las temporalidades que allí se tejen".

${ }_{96}^{6}$ Tradução nossa a partir do original: "allí también un presente en medio de la efectuación, de la composición y de la estimación, en medio del movimiento haciéndose, percibido de manera singular
} 
Segundo ela:

o trabalho sobre a gravidade próprio a uma dança que dirige sua atenção para o solo, para as relações de peso que movem o corpo, permite ver qualidades incomensuráveis, concretas, reais. Elas indicam tendências, qualidades que vão se dando e, por sua vez, se percebendo. A dança trabalharia então o mais próximo possível da percepção, para os bailarinos e bailarinas, e para o público, destas qualidades aparentes, dinâmicas, híbridas em suas texturas espaçotemporais. ${ }^{97}$ (BARDET, 2012, p. 166)

Para Bardet (2012), a temporalidade percebida pela relação com a gravidade, atenção e propriocepção dos movimentos tem o presente como mediador. Em uma atitude temporal caracterizada pelo acordo dos músculos posturais profundos, a sensação de peso e a orientação espacial, que continuamente estão em processo de atualizações, os movimentos (como variações de pesos, massas e forças) se enredam de maneira singular, pelos modos de organização de cada corpo, suas relações com o outro e com os objetos no ambiente contextual.

Além de Bardet, há outros pesquisadores em dança que compreendem a gravidade como uma temporalidade, como, por exemplo, a autora Laurence Louppe (2012). Para ela, a questão espaçotemporal da gravidade envolve o instante da presença, a "qualidade de estar lá", formada pelos cruzamentos de percepções em tempo real, permitindo ao bailarino e ao espectador instantes de experiências. A gravidade se desdobra em um fraseado que "consiste na organização sensorial e motora das durações, no fôlego interior que insufla uma temporalidade singular" (LOUPPE, 2012, p. 157).

Dinâmicas e modulações sutis, expressas com a gravidade, geram qualidades de movimento. Segundo a pesquisadora de dança Celine Roux, a gravidade envolve a temporalidade, na medida em que ela implica um "estar consciente do que se passa aqui e agora" (ROUX, 2007, p. 42). Isso porque a

por una aténcion gravitatoria, a través de la propiocepción de los movimientos de mi cuerpo en el espacio".

${ }^{97}$ Tradução nossa a partir do original: "el trabajo sobre la gravedad propio a una danza que dirige su atención sobre el suelo, sobre las relaciones de peso que mueven el cuerpo, permite ver cualidades, inconmensurables, y sin embargo concretas, reales. Sin ser extendidas de una vez por todas, senãlan tendencias, cualidades que se van dando y a la vez percibiendo. La danza trabajaría entonces este extensivo lo más cerca posible de la percepción, para los bailarines y las bailarinas, y para el público, de estas cualidades aparentes, dinámicas, híbridas en sus texturas espaciotemporales". 
temporalidade implica um estado de consciência ${ }^{98}$ que toma sentido na própria ação corporal, permite apreender os micromovimentos e romper com os automatismos. A temporalidade envolve a tensão, o relaxamento, as suspensões e vibrações do fluxo de energia do corpo. Segundo ela, essas qualidades são frequentemente exercidas, por exemplo, em práticas orientais, como a Yoga, o Tai-chi-chuan, o Aikido e o QiGong, e em práticas ocidentais com o trabalho sobre as intensidades de força de um movimento.

Quando Roux (2007) cita temporalidades imbuídas em práticas corporais, lembramos também de práticas somáticas, como o feldenkrais, por exemplo, que explora de forma intensa a temporalidade da gravidade, na percepção e escuta de cada parte do corpo. Exemplos disso são relaxar uma determinada musculatura ou soltar uma pequenina articulação em uma qualidade de atençao ativa e passiva de uma temporalidade expandida. "Para aprender, sugere Moshe Feldenkrais, precisamos de tempo, de atenção e de discernimento; para poder discernir, devemos sentir. Isso significa que para aprender, devemos afinar nossa aptidão de sentir"99 (FELDENKRAIS apud ROUX, 2007, p. 31).

Frequentemente a atenção à gravidade do movimento do corpo altera a própria percepção do tempo. Por exemplo, somos capazes de, com a gravidade, trabalhar somente as escápulas por quatro horas, sem nos dar conta da duração do tempo transcorrido. Não se trata apenas da forma de um movimento lento, mas da percepção da tensão e do relaxamento do corpo, que, além de produzir qualidades corporais, altera também a percepção temporal deste mesmo corpo.

Tomar consciência do peso do corpo faz parte da prática da dança e, para isso, é preciso tempo para desenvolver qualidades corporais que permitem afinar a aptidão do sentir e da atenção em relação ao próprio corpo. O trabalho sobre isso modifica as percepções temporais. Trabalhar o parâmetro temporal da gravidade implica imprevisibilidades e abertura de possibilidades, porque lida com uma consciência do corpo que não se dá pelo controle, mas sim por negociações com e no próprio corpo. Essas negociações geralmente mudam a percepção tanto do corpo quanto do tempo.

A exploração da gravidade indica um experienciar o movimento, porque ela

\footnotetext{
${ }^{98}$ Abordamos a temporalidade imbuída na consciência no último capítulo da presente pesquisa.

${ }^{99}$ Tradução nossa a partir do original: "pour apprendre, suggère Moshe Feldenkrais, nous avons besoin de temps, d'attention et de discernement; pour pouvoir discerner, nous devons sentir. Cela signifie que pour apprendre, nous devons affiner notre aptitude à sentir".
} 
requer uma atenção ao que se passa no momento presente da elaboração do movimento, no modo como ele é processado, envolvendo articulações, musculaturas, densidades, velocidades etc.

Segundo o autor Michel Bernard (1927-2015), "a gravidade age como um fio magnético que atravessa o corpo dos pés à cabeça, na qual a coluna vertebral tende constantemente a repulsar e atrair" (2001, p. 82). Para ele a "corporalidade dançante" é percebida como uma "dinâmica da metamorfose infinita ao tecer a temporalidade da gravidade" (BERNARD, 2001, p. 100).

Em concordância com o filósofo Paul Valéry, Bernard afirma que o corpo estabelece um diálogo com a gravidade de modo incessante de acordo com suas possibilidades, modulando as forças do corpo conforme suas astúcias.

Contudo, o olhar sobre os parâmetros temporais do movimento varia de uma época para outra - cada momento da história apresenta um determinado entendimento sobre tais parâmetros. Por exemplo, a gravidade foi muito explorada na dança moderna, como rejeição ao balé, que tem como principal característica a verticalidade. A relação entre a "verticalidade que requer resistência à gravidade e a horizontalidade que incentiva a entrega à gravidade" (COPELAND, 2004, p. 204) foi explorada na dança moderna ocidental. Os pioneiros da dança moderna - "de Duncan a Graham - rejeitaram o que eles acreditavam ser artificial no vocabulário do balé (e ortopedicamente destrutivo). [...] Duncan critica o balé por desafiar a lei natural da gravidade e por ligar passos e frases inorganicamente"100 (COPELAND, 2004, p. 64).

Nos tempos atuais, a exploração da gravidade tanto em práticas de estudo do movimento quanto em trabalhos artísticos parece estar relacionada ao desejo de subverter a aceleração das informações que atravessam o corpo cotidianamente, e as novas demandas advindas da quarta revolução industrial. ${ }^{101}$

Contudo, o trabalho com a gravidade envolve uma atenção ao movimento, um

${ }^{100}$ Tradução nossa a partir do original: "The early pioneers of modern dance - from Duncan through Graham - rejected what they believed to be the 'artificial' (and orthopedically unhealthy) vocabular of ballet in favor of movements more in keeping with the 'natural'inclinations of the body. Duncan criticizes ballet for defying the 'natural' law of gravity and for linking steps and phrases together inorganically".

${ }^{101}$ É no século XXI que a $4^{\circ}$ revolução industrial - caracterizada por uma revolução tecnológica, pelo fluxo e fusão de novas tecnologias, como a inteligência artificial, velocidade de informações de rede e novos sensores - possibilita que carros dirijam sozinhos, por exemplo. Essa revolução impactará o "mercado de trabalho, o futuro do trabalho e a desigualdade de renda." Disponível em: https://www.bbc.com/portuguese/geral-37658309. Acesso em: 10 set. 2018. 
modo de organização cotidiano, hábitos e comportamentos adquiridos ao longo da história de um corpo. A gravidade está envolvida na maneira como esse corpo anda, se alimenta e gesticula, e há um nível de percepção corporal diferente para cada um, por se tratar de uma organização que incorpora referências familiares, geracionais e culturais.

No capítulo anterior, abordamos como a coreógrafa Zélia Monteiro utiliza a gravidade em Danças Passageiras. Observamos a gravidade que acontece na gestão de apoios e equilíbrios, na escuta e atenção em sua improvisação, em relação ao fluxo de impulsos imagéticos e na memória de suas experiências passadas.

O parâmetro temporal da gravidade intervém na consciência e distribuições do peso do corpo, requer atenção ao estado presente, à percepção de movimentos e age na percepção de hábitos que replicamos sem nos dar conta.

Tendo em vista que trabalha com o peso, a dança é um poderoso ativador de estados de corpo passados. Ela mobiliza, com efeito, uma memória fundamental [...] inscrita na modelagem plástica dos tecidos que geram a organização tensional do corpo. (SUQUET, 2008, p. 528)

Ou seja, os movimentos percebidos no presente, com a gravidade, envolvem a memória desse corpo, os hábitos corporais que não esquecemos e que se inscrevem nas musculaturas profundas, na respiração, postura corporal e alinhamento articular, muscular e ósseo.

A gravidade frequentemente é trabalhada na improvisação em dança e na exploração de uma movimentação durante um processo de criação. Ela possibilita imprevisíveis desdobramentos na exploração da atenção e escuta das micro e macro mudanças corporais. A improvisação, compreendida como "composição no instante" (BOSSEUR, 1997, p. 52), procura a disponibilidade em capturar os acontecimentos que assolam 0 corpo. As imprevisibilidades que o corpo experimenta, através da exploração do movimento por meio da improvisação, apresentam modos pelos quais esse corpo se organiza, além de possibilitar estratégias de movimentação na construção de uma composição de dança. Entendemos que é com a exploração do movimento por meio da improvisação que surgem elementos que possibilitam uma composição. Esses elementos identificados 
ou descobertos na improvisação não apenas geram materiais para uma composição em dança, como também abrem caminho à construção como um todo.

Louppe (2012) defende que seja preciso distinguir a improvisação em dança das diferentes acepções desse termo em outros campos, tais como a poesia oral e a música tradicional, que trabalham com uma combinação imediata de variações e arranjos de um "léxico" já estabelecido. A improvisação também lida com hábitos e vocabulários corporais que cada corpo incorpora, referentes à sua experiência.

A gravidade está correlacionada ao peso, espaço e tônus do corpo, ela possibilita nuances de percepções ao longo da improvisação. "Improvisar é colocarse em situação de justaposição do presente, juntar nossas experiências e as possíveis em deixar vir e fazer vir um movimento imprevisto. O sentido do Kairós aqui é determinante" (LOUPPE, 2012, p. 165).

Assim, o trabalho sobre a gravidade contribui com a descoberta do movimento e suas singularidades, bem como com a estrutura e a proposição cênicas articuladas em cada obra. Contudo, dependendo de como ela é trabalhada e da época em que um parâmetro temporal do movimento tal como a gravidade é desdobrado, diferentes questionamentos são gerados.

Com o intuito de observarmos como os mesmos parâmetros temporais do movimento, como a gravidade, se desdobram de maneiras totalmente diferentes em cada obra, citamos outro exemplo que explora a gravidade. Trata-se da obra Men Walking Down on the Side of a Building, concebido pela coreógrafa norte-americana Trisha Brown (1936 -2017), que explorou a gravidade de modo a subvertê-la.

Trisha Brown, uma das artistas contestadoras da Judson Dance Theater, questiona nesse trabalho os códigos da representação. Em vez de utilizar o plano de composição horizontal, ela explorou outros chãos, com a caminhada na lateral de um prédio. Em Men Walking Down on the Side of a Building, os dançarinos caminham perpendicularmente pela parede de um prédio de sete andares na cidade de Nova York, em posição horizontal em relação ao chão, pendurados por um equipamento de escalada. Acontece, assim, o paradoxo de uma ação atuando contra outra, um desafio à gravidade. Ou seja, as questões temporais dessa coreografia tratam da própria experiência das ações corporais quando se veem confrontadas com a gravidade.

Os primeiros períodos desta criação de Brown, em torno de 1968 a 1970, acontecem com a proposição de utilizar equipamentos que investem o corpo em 
caminhadas sobre fachadas, colunas e muros. São proposições que estavam em concordância com o pensamento gerado pela Judson Church Danse (1970-1976). Nessa geração, mais do que a coreografia, é a experiência corporal que conta. Mesmo contando com o estudo de uma linguagem formal de coreografia e de composição com Louis Horst, ${ }^{102}$ Brown rompe com essa linguagem formal, apresentando eventos performativos como essa obra, que se manifesta fora de uma sala preta de teatro e desafia a gravidade.

Em Men Walking Down on the Side of a Building, a distribuição usual do corpo é subvertida com o descentramento do peso do corpo em relação às leis gravitacionais e com o imprevisto implicado nessas leis, gerando, além de uma mudança no vetor habitual do corpo do dançarino ao realizar a caminhada, "uma metamorfose de percepção por parte do espectador" (LOUPPE, 1993, p. 14).

Segundo a pesquisadora e coreógrafa Adriana Banana (2012), embora o campo gravitacional se aplique a todos os corpos neste planeta, cada corpo tem uma forma particular na distribuição de sua massa corpórea. "Apesar da similaridade de formas entre os humanos, nem seres co-espécies se movimentam da mesma maneira" (2012, p. 42).

\begin{abstract}
Entender a forma como ocorrem as relações entre corpos e gravidade é uma forma de auxiliar na percepção das diversas formas de dança, bem como das distintas assinaturas coreográficas. Sobre a relação da gravidade na dança, Roger Copeland (n.p., 1976) escreve que a dança clássica lida com a gravidade de forma ilusionista, como se esta não existisse, e a dança moderna exagera na apresentação da gravidade, enfatizando-a como uma força que puxa para baixo. Já Trisha não disfarça nem enfatiza o enorme esforço em realizar tarefas exaustivas. Sem dissimular ou acentuar a existência da gravidade, seus dançarinos apresentam-se como pessoas comuns que realizam tarefas incomuns, a exemplo do descer um prédio inteiro caminhando com o corpo paralelo ao chão. (BANANA, 2012, p. 43)
\end{abstract}

Segundo a jornalista de dança do Le Monde, Rosita Boisseau (2017), os Early Works de Trisha Brown, nos quais os dançarinos caminhavam pelas paredes do museu Whitney, apresentavam uma "progressão de coisas" na concepção da

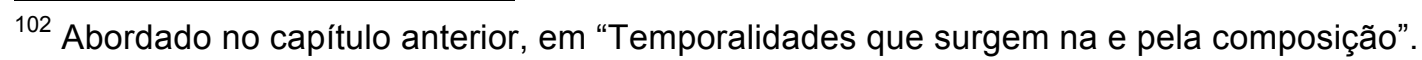


dramaturgia que, segundo Brown, "tinha um começo, um meio e depois um fim."103 (BROWN, 2017, p. 17).

Segundo Fontaine (2004), uma das principais pesquisas de Brown consiste no princípio de acumulação, "que trata de repetir um movimento um certo número de vezes e a ele adicionar um outro, conservando a clareza e a independência de cada movimento"104 (FONTAINE, 2004, p. 210). Esses pontos foram trabalhados em suas obras Accumulation (1971), Accumulation with Talking (1973) e Group Primary Accumulation (1973). Para Fontaine (2004), Trisha Brown elabora uma lógica temporal do movimento que se modifica na medida em que

o começo de um movimento em uma parte do corpo se transporta a outro movimento que ainda não foi terminado, ou, ao contrário, o fim de um movimento corresponde ao começo de um outro [...] uma série de frases pode dificilmente ser decomposta, posto que os começos e os fins se entrelaçam. ${ }^{105}$ (FONTAINE, 2004, p. 121)

Embora haja leituras das obras de Brown que as aproximem de uma abordagem minimalista, "de repetição [...], a distribuição do peso sobre o solo amortece as transferências gravitacionais localizadas e conferem a elas uma qualidade única, um preenchimento macio, de suavidade e de liberdade" (LOUPPE,1993, p.14, 15).

$\mathrm{Na}$ ocasião do $40^{\circ}$ Festival de Avignon, o alpinista Antoine Le Menestrel apresenta, no dia 23 de fevereiro de 2017, o espetáculo de dança Debout (2017), em homenagem à Trisha Brown. Descendo a igreja dos Célestins, a apresentação ocorre na fachada da construção desativada. O dançarino e alpinista, sem pronunciar nenhuma fala, caminhava pelas paredes e pelo teto da igreja, conduzindo o espectador a entrar e sair desse lugar, traçando o começo, meio e fim do espetáculo, pelas conduções de entrada, ocupação e saída do público da igreja. Ele começou fora do prédio, caminhando sobre o teto, depois abriu as portas da igreja

${ }^{103}$ Tradução nossa a partir do original: "marcher sur les murs du Whtney Museum avait un début, un milieu et puis une fin".

${ }^{104}$ Tradução nossa a partir do original: "le principe d'accumulation, utilisé pour une dizaine de pièces, solos et danses de groupe, de 1971 à 1979). II s'agit de répéter un mouvement un certain nombre de fois et de lui en rajouter un autre, en conservant la clarté et l'indépendance de chaque mouvement".

${ }^{105}$ Tradução nossa a partir do original: "La logique temporelle du mouvement est pertubée: le début d'un mouvement dans une partie du corps prend le relais d'un autre mouvement qui n'est pas encore achevé, ou, à l'inverse, la fin d'un mouvement correspond au début d'un autre. [...] Ce mode d'enchaînement crée une continuité inlassable, une série de phrases peut difficlement être décomposée puisque les débuts et les fins s'entrelacent". 
para a entrada do público, caminhou pelas paredes internas, que apresentavam diversos vídeos dos trabalhos artísticos de Trisha Brown, e, ao final, conduziu o público à saída. A gravidade do seu corpo ocupou e foi envolvida por todo o espaço da igreja, sua corporalidade conduziu o olhar do espectador a uma certa direção de caminhada. Uma dramaturgia do corpo foi apresentada num fazer cênico "grandioso", no sentido de dimensão espacial, ao escalar a igreja entrecruzando os campos do circo e da dança.

Observamos um outro desdobramento da gravidade com as obras Brevidades de Helena Bastos. Como abordamos no capítulo anterior, a gravidade neste trabalho atua nas organizações do peso, na relação entre corpo e bastões. Ao final de Brevidades, todos os performers vivenciam suas quedas de acordo com as possibilidades de cada um. A gravidade possibilita uma transversalidade de diversos descentramentos espaçotemporais. O plano de composição tanto de Brevidades quanto de Esculturas Breves, diferentemente de tomar o chão como um espaço neutro, exploram precisamente o chão da cidade. A gravidade em Brevidades e Esculturas Breves permite uma orientação espacial de diversas e diferentes direções e descentramentos temporais, provocados pelo peso dos bastões e reverberações do movimento do outro pelas fitas crepes. A gravidade em Esculturas Breves e Brevidades possibilita transições e atualizações dos movimentos e das imagens que tais trabalhos geram. Nesses trabalhos, a gravidade contribuiu para os questionamentos acerca da demanda imperiosa de estarmos em permanente produção. Como abordamos com os exemplos de Brevidades, Danças Passageiras, Nó(s), Men Walking Down on the Side of a Building e Debout, a gravidade colabora para os questionamentos de proposições artísticas contemporâneas. No contexto atual da sociedade pós-industrial do século $X X I$, em que os questionamentos da dança se orientam em resistência ao fluxo, à rapidez e à flexibilização de uma ordem dominante que prega a produção, a gravidade parece se relacionar diretamente com o fluxo. "A esta noção de fluxo adiciona-se, nos parece, a produção e a necessária resistência para impedir esse ciclo de produtividade cada vez maior" 106 (ROUX, 2007 , p. 9). Mas será que o fluxo estaria apenas vinculado a este contexto?

\footnotetext{
106 "Pour Isabelle Ginot, ces questionnements son à repenser dans une contexualisation plus globale qui déborde le seul champ esthétique et ils développent une résistance face à l'ordre dominant - c'est-à-dire politique et économique - qui prône sans cesse le flux, la rapidité et la flexibilité dans une mondialisation en marche. À cette notion de flux s'ajoute celle, nous semble-t-il, de la production et de la nécessaire résistance à enrayer ce cycle de productivité toujours amplifiée".
} 


\subsection{O Fluxo e a obra So Blue}

O fluxo também é compreendido nesta pesquisa como um parâmetro temporal do movimento, que indica a continuidade do impulso de uma ação. Segundo a pesquisadora Johnstone (1980), "o fluxo em dança revela uma qualidade tensional específica e a maneira como ela é projetada conduzirá sua temporalidade" ${ }^{107}$ (p. 88). O fluxo se revela em toda dança, ao implicar uma dinâmica qualitativa do movimento.

Klauss Vianna (2005) também traz proposições em torno do fluxo. Segundo ele, "para que se consiga tornar fluente o movimento é indispensável o trabalho sobre a liberação de uma dada articulação e o reconhecimento de como suspendêla" (p. 101). Descobrir essas diferenças relativas ao domínio sobre a articulação e suas possibilidades de movimento permitem uma dinâmica corporal.

A ideia de que o fluxo implica qualidades de movimentação também é promovida pelo coreógrafo e artista plástico Rudolf Laban, que desenvolveu e sistematizou seus estudos sobre fluxo, tempo, peso e espaço, no sistema de linguagem do movimento denominado Laban Movement Analysis (LMA) ou Sistema Laban. O fluxo é um fator importante do movimento porque ele corresponde à sua fluência, qualidade que pode ser trabalhada com diversas variáveis de intensidades tônicas. A tonicidade e os músculos intervêm na qualidade do fluxo. Segundo ele, "tanto o fluxo livre quanto o controlado pedem uma tensão muscular" (FERNANDES, 2006, p. 123). Para Laban, o fluxo ganha muito mais uma dimensão espacial do que temporal, na medida em que o fluxo está ligado ao deslocamento do peso do corpo no espaço. Segundo o Sistema Laban (2006), o fator tempo está implicado na ênfase qualitativa que determina se o movimento acelera ou desacelera, o tempo pode ser desacelerado, súbito e acelerado.

O fator tempo relaciona-se com o "quando" do movimento, a intuição e a decisão ao realizá-lo. E os sistemas endócrino e nervoso são os principais responsáveis por esta qualidade de apressar-se rumo ao

107 "Thus, the basis for the flow of force in dance, its dynamics line, is projectional and tensional quality: a sheer force of whatever potency is qualitatively projected, and the manner of its projection will govern its temporality." 
futuro (aceleração, urgência), ou prorrogá-lo (desaceleração). (FERNANDES, 2006, p. 135)

Além da relação entre fluxo e velocidade, ele colabora no entendimento de que o fluxo permite o ritmo. Segundo Laban, o ritmo-tempo lida com o fluxo do movimento. Ele pode ter durações de "um ritmo regular (tempo 2/4) que pode trazer uma qualidade mais monótona do que uma irregular de (3 ou 5 tempos), o ritmo regular é restritivo e o ritmo irregular impulsionador" (LABAN, 1966, p. 208). Esse ritmo também é relacionado aos estados corporais, por exemplo, os "estados expressivos" que se compõem pelo "estado rítmico", no qual estão relacionados os fatores: peso e tempo; "estado onírico" com a combinação de peso e fluxo; "estado de alerta" na combinação de tempo e espaço; e "estado remoto" na articulação dos fatores fluxo e espaço.

Observamos, assim, que o fluxo implica ritmo. "Relembremos a etimologia da palavra 'ritmo', que Benveniste associa à primeira acepção em grego, antes do século IV, segundo a qual ruthmos remete para a 'forma', ou seja, para o modo como um corpo flui no mundo" (LOUPPE, 2012, p. 170).

A pesquisadora Johnstone (1980) acrescenta que, embora o ritmo implique o fluxo como uma força temporal de relação, sua característica em dança é o da não pré-determinação. "Podemos dizer de um fluxo temporal específico de um movimento específico e o tempo da dança como um campo criado por temporalidades e tempo" 108 . Considerando que o tempo não é algo que pré-existe, isto é, ele é criado pela dança mesma, Johnstone explica que o ritmo existe especificamente apenas em relação a um movimento específico.

Para Louppe (2012), o "ritmo é uma espécie de intercâmbio entre os sinais dados pelo ambiente [...] e o corpo que os integra" (p. 168). Para ela, o ritmo não é uma marcação periódica, mas se encontra por meio de nuances da textura muscular, textura nervosa, respiração, alternância de apoios e tonicidade. A "experiência rítmica aproxima-se das variações da experiência emocional e da vida emotiva do indivíduo em geral" (LOUPPE, p. 168), uma variação que está ligada à adaptação ao meio.

\footnotetext{
${ }^{108}$ Tradução nossa a partir do original: "one can speak of the specific temporal flow of a specific movement and the time of the dance as a whole as created temporality and created time. Because time is not a thing which pre-exists and awaits carving up by the dancer, because it is something created by the dance itself, it exists specifically only in relation to a specific movement within the dance."
} 
No capítulo anterior, abordamos o fluxo percebido em Esculturas Breves e Brevidades. Esses trabalhos lidam com um fluxo de movimentos e transições cautelosas no compartilhamento de ações e manipulações de objetos, um fluxo de escuta expandida, justamente na escuta das ações, no ralentar e no silêncio em meio ao espaço urbano, dialogando com um contrafluxo acelerado da cidade.

O fluxo dos impulsos imagéticos percebido em Danças Passageiras parece lidar com a consciência e a memória nas decisões e escolhas a todo momento tomadas, com a intenção de permanecer no instante e liberar-se de automatismos. Percebemos, nesse caso, que as continuidades de um impulso do movimento acontecem por um fluxo irregular.

Mas o fluxo é um parâmetro temporal do movimento que apresenta diferentes pensamentos segundo momentos históricos. Segundo Lepecki (2006), a ideia do contínuo movimento implicada no fluxo faz parte da história da dança. Segundo ele, isso ocorre em um projeto da modernidade no qual o desenvolvimento da dança aparece como uma forma autônoma da arte no Ocidente. Isso ocorre a partir do Renascimento, que se alinha com o ideal da máquina cinética a qual constantemente produz o movimento linear e progressivo, em uma lógica de produtividade.

\begin{abstract}
A maioria dos coreógrafos da dança moderna atribui o ritmo acelerado da vida moderna a uma variedade ou outra doença urbana (isto é a ganância do consumismo, e da aquisição que presumivelmente domina as sociedades voltadas para o dinheiro). Em outra variação sobre o tema do mal-estar urbano, o movimento rápido está associado com [...] o corpo que se torna um instrumento de precisão tecnocrática; e os ritmos da produção de massa industrial são pensados para não terem pena de se impor a isso. Isso ajuda a explicar porque os partidários das técnicas de Graham, Humphrey e Limón ficaram chocados quando encontraram Cunningham usando um cronômetro para trabalhar o tempo com seus dançarinos, na década de $1950 .{ }^{109}$ (COPELAND, 2004, p. 85)
\end{abstract}

\footnotetext{
109 Tradução nossa a partir do original: "Most modern dance choreographers attribute the accelerated pace of modern life to one variety or another of urban ladady (i.e., the ethos of greed, consumerism, and acquisitiveness that presumably dominates money-driven societies). In another variation on the theme of urban malaise, rapid movement is associated with F.W Taylor's assemblyline, time-and-motion efficiency studies (otherwise known as 'scientific management'). The body becomes an instrument of technocratic precision; and the rhythms of industrial mass production are thought to be ruthlessly imposed on in. This helps explain why the partisans of Graham, Humphrey, and Limón technique were so appalled when they first encountered Cunningham using a stopwatch to time his dancers in the 1950s".
} 
Em contraposição à lógica hegemônica da produtividade, Lepecki (2006) propõe a temporalidade do stillness, a partir do still-act proposto por Nadja Seremetakis. Essa temporalidade propõe distintas maneiras de ralentar o movimento pelo desenvolvimento de diferentes meios de desaceleração, silêncio e quietude na dança, além do desenvolvimento de diversas formas de desaceleração do movimento e do tempo.

O "still-act" é um conceito proposto pela antropóloga Nadia Seremetakis para descrever momentos em que o sujeito interrompe o fluxo histórico. Assim, enquanto o still-act (ainda ato) não implica rigidez ou mobilidade isto exige uma performance da suspensão, uma corporeidade baseada na interrupção dos modos de impor fluxo. O still act (o ainda) age porque este interroga economias do tempo, porque ele revela a possibilidade de agenciamentos dentro do controle do regime de capitais, subjetividade, trabalho, e mobilidade. "Contra a fluidez do presente", Seremetakis escreve, T(here) aqui é uma quietude na cultura material da historicidade; aquelas coisas, espaços, gestos, e contos que significam a capacidade perceptiva para criação histórica. A quietude, calma é o momento do falecido, o descartado e a fuga esquecida para a superfície social da consciência. É o momento de saída do pó histórico. (LEPECKI, 2006, p. 15)

Com essa temporalidade da quietude ou stillness, Lepecki (2006) constitui uma crítica à mobilidade permanente do movimento. Ele aponta uma preocupação com a dança que propõe a exibição de corpos em movimento em estado de constante agitação, em contínuo fluxo.

Segundo Cunningham, a quietude é uma temporalidade que age no movimento sem um antes e um depois. E essa temporalidade possibilita uma resistência ao ritmo acelerado da produção do mercado da arte. "Cunningham, em estreita associação com seu parceiro e colaborador musical, John Cage, inspirou-se na variedade de antigas fontes asiáticas, como o I Ching e a prática do Zen Budismo" 110 (COPELAND, 2004, pp. 2-3). A quietude, na obra desse artista, é articulada em relação ao silêncio proposto pelo músico John Cage. Para o coreógrafo, "a natureza da dança é a quietude em movimento e o movimento na

\footnotetext{
${ }^{110}$ Tradução nossa a partir do original: "Granted, Cunningham, in close association with his partner and musical collaborator, John Cage, has drawn inspiration from a variety of ancient Asian sources such as the I Ching and key practices of Zen Buddhism".
} 
quietude"111 (COPELAND, 2004, p. 98). Nenhuma quietude existe sem movimento e nenhum movimento é plenamente expresso sem quietude.

Por outro lado, o fluxo é visto por certos artistas de outros pontos de vista. Não necessariamente como uma crítica à rentabilidade ou ao contínuo movimento progressivo, como a lógica da produtividade, sobre a qual Lepecki nos propõe a pensar. O fluxo é explorado com outros sentidos, como, por exemplo, na obra So Blue (2012), concebida pela coreógrafa canadense Louise Lecavalier. Diferente da ideia de fluxo exposta acima, So Blue trabalha com uma noção de fluxo como um exercício de liberdade, uma supressão de restrições. Nessa obra, subsiste a ideia de, com o fluxo, ultrapassar os limites que o próprio corpo pode impor. Para o coreógrafo Édouard Lock, diretor da companhia La La La Human Steps, a velocidade em fluxo permite ir "para o limite do seu controle". ${ }^{112}$

So Blue ${ }^{113}$ foi criada em 2012 pela dançarina Louise Lecavalier, dançarina da companhia La La La Human Steps, de 1981 a 1999, e interpretada com seu parceiro de cena, Frédéric Tavernini. Para Lecavalier, a obra So Blue apresenta o desejo de "permitir que o corpo diga tudo o que ele quer dizer ou se supreender ao ser revelado, sem censurá-lo". ${ }^{114}$ O fluxo, a rapidez e a simultaneidade das ações corporais são temporalidades percebidas nessa obra. Contudo, a repetição também compõe a sua estrutura: "muito do material em loop coreográfico de Lecavalier [...] evoca treinos: exercícios de permanência transferidos para um corpo dançante. No final de uma sessão, ela se refresca em frente a um ventilador e, depois retoma seus espamos repetitivos" (KOURLAS, 2015), ${ }^{115}$ diz a crítica do jornal New York Times. A obra So blue revela parâmetros temporais do fluxo, da rapidez, da simultaneidade e da repetição, construídos de acordo com a elaboração do pensamento cênico. A combinação e organização destes parâmetros permitem a coerência da dramaturgia

\footnotetext{
111 Tradução nossa a partir do original: "The nature of dancing is stillness in movement and movement in stillness".

112 Disponível em: http://articles.latimes.com/2012/jan/25/entertainment/la-et-edouard-lock20120125. Acesso em: 18 jul. 2018.

${ }_{113}$ Disponível em: https://www.youtube.com/watch?v=F516qFx7zdw. Acesso em: 17 jul. 2018.

114 Disponível em: https://www.nytimes.com/2015/09/11/arts/dance/review-louise-lecavalier-is-atyphoon-of-physicality-in-so-blue.html. Acesso em: 19 jul. 2018.

${ }^{115}$ Tradução nossa a partir do original: "Much of the material in Ms. Lecavalier's choregraphed loops [...] evokes gym drills: endurance exercises transferred to a dancer's body. At the end of one sessession, she cools off in front of a fan and then resumes her repetitive twitching while bowing forward in child's pose, a resting position in yoga." Disponível em: https://www.nytimes.com/2015/09/11/arts/dance/review-louise-lecavalier-is-a-typhoon-of-physicalityin-so-blue.html. Acesso em: 19 jul.2018.
} 
de So Blue.

Observamos assim, diferentes pontos de vista acerca do fluxo. No entanto, ele se constitui como um parâmetro temporal do movimento que revela pensamentos, concepções e questionamentos relacionados ao contexto histórico e ao ambiente onde é elaborado. O fluxo, bem como os outros parâmetros abordados nesta pesquisa, não são dados de antemão, mas criados a cada composição de acordo com diferentes combinações de um processo artístico. 


\subsection{A Repetição em diferentes obras}

Consideramos a repetição outro parâmetro temporal frequentemente trabalhado em dança contemporânea. Compreendemos que ela explora a tensão entre o presente e o devir, em um processo de retomadas e transformações. Ao refazermos algo, uma nova seleção é feita.

A repetição não é compreendida aqui como reprodução do mesmo; repetir implica uma singularidade, uma diferenciação, produzimos alguma coisa nova com a condição de repetir. "Pensa-se como a repetição se tece de um ponto relevante a um outro, compreendendo em si as diferenças" (DELEUZE, 1988, p. 35).

Em relação a um corpo máquina, a repetição pode ser pensada como semelhança idêntica ou equivalência perfeita; porém, o corpo em dança, ao refazer uma ação, passa de uma coisa à outra, de modo que se opere um deslocamento temporal que já o modifique.

Repetir denota acontecer de novo. Em francês, a palavra repetir - répéter significa ensaiar. Em um processo de criação em dança, algo sempre se transforma ao ser refeito. Ao refazer uma ação, novas percepções, ${ }^{116}$ memórias e experiências se conectam com esse acontecer de novo a cada ensaio.

Segundo o sociólogo norte-americano Richard Sennett (2009), a repetição de uma ação permite o desenvolvimento de habilidades, porque a repetição implica a avaliação e o questionamento na busca de aprimoramento. Ao fazer e refazer uma ação específica, novas qualidades são agregadas porque outras informações, conceitos e hipóteses são testados. Ao realizar o que o autor chama de "habilidade artesanal", ou seja, uma atividade específica, são desenvolvidas habilidades diversas que requerem um diálogo entre o fazer e o pensar, na busca por soluções para os problemas e proposições. A repetição permite a construção e o aperfeiçoamento de formulações como pensamento, imagens, imaginação e memórias. Ou seja, é com a repetição que habilidades e ações são qualificadas e requalificadas.

\footnotetext{
116 "Resumidamente, a percepção do movimento caracteriza-se como um sistema sensível à informação, capaz de identificar e discriminar as diferentes qualidades das múltiplas e constantes informações provenientes do meio interno e externo, realizando operações que têm como propósito a adequação e a eficiência adaptativa de nossas ações". (HERCOLES, 2011, p. 26).
} 
Embora a repetição não seja o parâmetro temporal que orienta as ações performativas de Esculturas Breves e Brevidades, nesses acontecimentos performativos percebemos a repetição do hábito de ir para a rua para as experiências artísticas, em um aperfeiçoamento do roteiro aberto das ações e aprimoramento da habilidade de cooperação. De todo modo, a repetição não é muito explorada na performance, porque mesmo a sua própria repetição marca uma diferença, a "performance acontece ao longo de um tempo que não será repetido"117 (PHELAN, 1996, p. 146).

Já no trabalho Nó(s), a repetição é o parâmetro temporal trabalhado principalmente nas sequências coreográficas da última cena, realizada em diferentes trajetos. Ao realizar a cada vez essas frases de movimentos, contudo, elas modificam completamente os estados, a atenção e o nível de comunicação entre o dueto.

A repetição não é uma generalidade, porque compreendemos que "repetir é comportar-se em relação a algo singular, algo que não tem semelhante ou equivalente" (DELEUZE, 2006, p. 1). Segundo Deleuze, o fato de uma coisa passar para outra não as previne de diferenças tipológicas. A repetição de algo em outro contexto ou deslocamento já implica diferenças.

Percebemos que a repetição também não é o parâmetro de Danças Passageiras, trabalho que lida com a improvisação. Porém, as seleções e decisões criadas a partir de novas informações percebidas pelo corpo implicam também uma consciência das ações realizadas pelos hábitos adquiridos, que acontecem justamente por meio da repetição. Percebemos, em Danças Passageiras, que os hábitos são utilizados para deles subtrair algo novo.

A relação entre a memória e a repetição está no hábito que se atualiza pelo esquema motor, a repetição "desenvolve, a cada tentativa, movimentos enredados; a cada vez chama a atenção do corpo para um novo detalhe que havia passado despercebido [...] um movimento é aprendido tão logo o corpo o compreendeu" (BERGSON, 1990, p. 89).

Na obra So blue, que começamos a abordar com o parâmetro fluxo, explora a repetição, por exemplo, de "um movimento de fuga rápida dos pés, que se repetiu ao longo da peça variando intensidades e velocidades, e que formou a coluna vertebral

\footnotetext{
117 Tradução nossa a partir do original: "Performance occurs over a time which will not be repeated. It can be performed again, but this repetition itself marks it as 'different'".
} 
da coreografia"118 (2015).

Em Accumulations ${ }^{119}$ (1971-1975), de Trisha Brown, que começamos a abordar com a gravidade, a repetição parece assumir grande relevo. Além do parâmetro temporal da gravidade trabalhada na estrutura dramatúrgica de Early Works, Trisha Brown também explorou a repetição em Accumulation, "um nome que visa exatamente à condução artística da coreógrafa inspirada pela espiral e pela repetição" ${ }^{120}$, como afirma a crítica de dança Rosita Boisseau, do jornal Le Monde (2017, p. 16). A repetição de movimentos em Accumulation acontece em uma sucessão e fluxo de sobreposições de movimentos, que vão pouco a pouco sendo introduzidos em uma cadência fluída das transferências de pesos e das mudanças espaciais. Brown utiliza a repetição de cada movimento em um fluxo que permite observarmos cada elemento novo que chega à coreografia de Accumulation.

A repetição em uma dramaturgia também pode propiciar ao espectador uma memorização do que ele vê. Com esse recurso, é possível ressaltar um elemento de diferenciação ou mesmo de transformação e desenvolvimento na duração de uma estrutura cênica. De acordo com a autora Peggy Phelan, "cada repetição de uma imagem, por marcar ou remarcar sua perpétua construção e reconstrução" (1996, p. 99), implica a emergência de um novo. A repetição requer uma memória, para que seja possível perceber o que de diferente foi evocado em relação ao que procedeu ou ao que seguiu. Apresentar uma ação habitual de repetição pode ser uma estratégia de cena para evocar a memória do espectador.

De acordo com Fontaine (2004), a repetição explorada na estrutura de uma peça de dança pode propor "um jogo entre a capacidade de reconhecer os elementos utilizados para vê-los de forma diferente ou para ser surpreendido"121 (FONTAINE, 2004, p. 196).

118 Tradução nossa a partir do original: "A motion of quick scuttling feet, which was repeated throughout the piece at varying intensities and speeds, formed the backbone of the choreography". Disponível em: http://globedancer.com/so-blue-louise-lecavalier/. PuSh International Performing Arts Festival, Vancouver. Acesso em: 21 jul. 2018.

119 Diponível em: https://www.youtube.com/watch?v=86I6icDKH3M. Acesso em: 15 jun. 2018.

120 Tradução a partir do original: "Ses performances sont noyautées par la construction lente mais précise de son vocabulaire et de sa syntaxe, qu'elle va regrouper sous le titre générique d'Accumulaions (1971-1975). Un nom qui cible exactement la conduite artistique de la chorégraphe aspirée par la spirale de son geste répétitif."

121 Tradução nossa a partir do original: "La répétition favorise aussi la mémorisation de ce que l'on voit, elle propose un jeu entre la possibilité de reconnaître des éléments utilisés, de les voir différemment ou d'être surpris". 
Uma das coreógrafas que explorou o parâmetro temporal da repetição em suas peças foi a alemã Pina Bausch. Por exemplo, em uma das cenas de Café Müller ${ }^{122}$ : nela, os dançarinos Dominique Mercy e Malou Airaudo executam uma frase de movimentação conjunta composta pelas ações de se beijar, se abraçar e se agarrar, feitas e desfeitas em repetição com a colaboração do terceiro dançarino Rolf Borzik. Logo no início da mesma peça, também há a repetição apresentada em outro sentido completamente diferente, como eco fantasmagórico do ínicio de Café Müller. São repetições que se manifestam com sentidos diferentes na peça, mas que estabelecem diálogo entre as cenas. Em outro trabalho da coreógrafa, exibida numa das cenas do filme Pina, ${ }^{123}$ já mencionado nesta tese, há um modo de repetição que também faz parte da peça Como el musguito en la piedra, ay si, si, si. O título foi retirado de uma canção de Violeta Parra, em homenagem a Victor Jara. Nessas cenas, que inclusive citei anteriormente, a dançarina Tsai-Chin Yu aparece sendo constantemente puxada por uma corda. Tsai Chin corre em uma espacialidade de meia-lua e sempre retorna, em razão de uma corda que fica amarrada em um suporte na coxia do teatro.

Percebemos, assim, diferentes procedimentos que exploram o parâmetro temporal da repetição. Ela age também como estratégia de criação em dança. Além de aparecer na cadência de uma divisão regular do tempo, a repetição pode revelar diferenças, ser usada como estratégia de dramaturgia, além de invariavelmente estar ligada à memória e hábitos adquiridos do corpo.

\footnotetext{
${ }^{122}$ Visualização disponível em: https://www.youtube.com/watch?v=WZd2SkydIXA Acesso em: 15 nov. 2016.

${ }^{123}$ Visualização disponível em: http://www.pina-film.de/en/trailer.html Acesso em: 15 nov. 2016.
} 


\subsection{O Uníssono e as obras Fase e Tempo 76}

O uníssono indica um acordo ou união de diferentes corpos que se reúnem para realizar as mesmas ações, em um mesmo espaço-tempo, de modo simultâneo. O parâmetro temporal do uníssono também é recorrente em dança e se constitui como ponto de partida para criações.

O significado do uníssono refere-se ao campo musical, pela emissão simultânea de um mesmo som, como, por exemplo, o canto coral, no qual o uníssono é composto pela pluralidade de várias vozes singulares. Mas ele também é atualmente frequentemente utilizado no campo da dança contemporânea.

Contudo, segundo Fontaine (2018) "nos anos 1980 e 1990 o uníssono foi pouco utilizado na dança contemporânea por ser considerado muito próximo da dança clássica, do musicólogo e etc" (Informação verbal). ${ }^{124}$ Nesse contexto, a obra Fase: quatro movimentos para a música de Steve Reich ${ }^{125}$ (1982), dirigido por Anne Teresa de Keersmaeker, teve grande relevância ao explorar o uníssono.

O uníssono, em dança contemporânea, é material temporal de tensões de oposição. Ele acontece pelo conjunto, mas também pelas singularidades: indica semelhanças, mas também diferenças. Como exemplo dessas oposições entre singular e plural, semelhante e diferente, que constroem o tempo uníssono, podemos observar a obra Tempo 76 (2007), concebida pela coreógrafa francesa Mathilde Monnier. Sobre o uníssono, a coreógrafa afirma: "Lembro-me de que nos anos 80, época de explosão da dança contemporânea na França, ele representava para a comunidade da dança uma forma relativamente tabu, mas suficientemente utilizável para produzir efeitos espetaculares" ${ }^{126}$ (2018).

\footnotetext{
${ }_{124}$ Entrevista à Tatiana Melitello: "En danse contemporaine, dans les années 1980 et 1990, l'unisson était peu utilisé dans la danse contemporaine parce qu'il était considéré comme très proche de la danse classique, du musicologue, etc".

${ }^{125}$ Link de Fase no Youtube: https://www.youtube.com/watch?v=RTke1tQztpQ Acesso em: 26 out. 2016.

${ }^{126}$ Tradução nossa a partir do original: "Je me souviens que dans les années 80 , au moment de l'explosion de la danse contemporaine en France, elle représentait pour la communauté de la danse une forme relativement taboue mais néanmoins assez utilisable pour produire des effets spectaculaires de fin de spectacle." Disponível em: http://www.cndp.fr/crdpreims/poletheatre/service_educatif/mathilde_monnier.pdf. Acesso em: 21 jul. 2018.
} 
Na obra Tempo 76, os dançarinos dançam, se deslocam, gesticulam, riem, se vestem, executando as mesmas ações ao mesmo momento e no mesmo espaçotempo da cena, mas de maneira totalmente diferente entre si. Mathilde Monnier subverte o uníssono. Segundo ela,

nós vivemos desajeitadamente em uníssono no mundo. Nós tentamos nos ajustar ao rítmo de um mundo que nos ultrapassa. Nós tentamos nos adaptar a um ambiente cada vez mais hostil, cada vez mais rápido, cada vez menos apreensível e compreensível. ${ }^{127}$ (MONNIER, 2008)

Questionada sobre o porquê de ter tomado o uníssono como um príncipio diretor de Tempo 76, Mathilde Monnier responde:

O uníssono é antes de tudo uma forma coreográfica que apresenta essa estranheza de circular tanto no campo do entretenimento (balés aquáticos, shows, pom-pom-girls, music hall... e no campo da disciplina (desfiles militares, esportivos, líderes de torcidas...). Essas formas espetaculares sempre me fascinaram, mas me pareciam como um modelo impossível de utilizar em meu trabalho de coreógrafa e criando um tipo de tensão. É então em torno dessa fascinação plena de contradições que eu escolhi reapropriar a figura do uníssono na tentativa de colocá-lo a serviço dos intérpretes - e não a serviço de uma mensagem ou de uma representação gloriosa. ${ }^{128}$ (MONNIER, 2008)

Outro exemplo de uníssono, em que podemos observar que o mesmo parâmetro temporal do movimento se desdobra de maneira muito diferente de acordo com cada artista e obra, é Fase: quatro movimentos para a música de Steve

${ }^{127}$ Tradução nossa a partir do original: "Nous vivons maladrotement à l'unisson du monde. Nous tentons de nous raccrocher au rythme d'un monde qui nous dépasse. Nous tentons de nous adapter à un environnement de plus en plus hostile, de plus en plus rapide, de moins en moins appéhendable et compréhensible." Tempo 76. Dossie Pedagógico. 2008. Disponível em: http://www.cndp.fr/crdpreims/poletheatre/service_educatif/mathilde_monnier.pdf. Acesso em: 21 jul.2018.

${ }^{128}$ Tradução nossa a partir do original: "L'unisson est d'abord une forme chorégraphique qui présente cette étrangeté de circuler à la fois dans le domaine du divertissement (ballets aquatiques, revues de music-hall...) et dans le domaine de la discipline (défilés miliaires, sportifs, majorettes...). Ces formes spectaculaires m'ont toujours fasciné et accompagné dans ma vie mais elles restaient figées, m'apparaissant comme un modèle impossible à utiliser dans mon métier de chorégraphe et créant même une sorte de crispation, C'est donc autour de cette fascination pleine des contradictions que j'ai choisi de me réapproprier la figure de l'unisson en tentant de la mettre au service des interprètes -et non au service d'un message ou d'une représentation glorieuse". Disponível em: http://www.cndp.fr/crdp-reims/poletheatre/service_educatif/mathilde_monnier.pdf. Acesso em: 21 jul.2018. 
Reich. ${ }^{129}$ Em um dueto, formado por Keersmaeker e Michèle Anne de Mey, as qualidades temporais trabalhadas na obra são apresentadas por meio de uma dinâmica de movimentos estritamente bem marcados e definidos, em concordância com a música minimalista do estadunidense Steve Reich.

Fase: quatro movimentos para a música de Steve Reich é um trabalho coreográfico composto por células de movimentos previamente estruturadas em uma sequência coreográfica definida. O uníssono do movimento aparece em um vocabulário coreográfico simples, que se repete por um sistema algorítmico complexo de acordo com um tempo musical, e esse vínculo é criado com a música minimalista de Reich. A relação entre o movimento e o tempo musical remete ao vocabulário coreográfico dos primeiros trabalhos de Keersmaeker. Ao referir-se aos seus próprios trabalhos, ela afirma: "com eles, consigo ver melhor como posso buscar o máximo que é o mínimo. Quero praticar uma economia dos meios para reduzir o movimento ao que, de fato, interessa. Quero manter tudo muito simples"130 (KATZ, 2011). Fase deu início à sua companhia Rosas. Até os dias de hoje, o vínculo entre música e dança é uma característica que permeia todas as suas criações coreográficas (KATZ, 2011).

A relação entre música e a coreografia de Fase é realizada de modo processual e gradual. Segundo Reich, "o material pode sugerir que tipo de processo deve ser executado - conteúdo sugere forma -, e o processo pode sugerir que tipo de material deverá ser executado através deles - forma sugere conteúdo" ${ }^{131}$ (REICH, 2002, p. 34). Para Reich, o processo musical abordado de forma gradual convida a uma atenção sustentada, como, por exemplo: "ao observarmos o movimento dos ponteiros de um relógio, com ele percebemos um processo gradual do tempo, no qual as mudanças de movimento dos ponteiros são percebidas depois de ficar observando o relógio por um tempo" (REICH, 2002, p. 36).

O tempo musical não se apresenta de modo hierárquico em relação ao movimento, ele é trabalhado em Fase: quatro movimentos para a música de Steve Reich se relacionando com a coreografia. Em Fase, a coreografia, assim como a

${ }^{129}$ Link de Fase no Youtube: https://www.youtube.com/watch?v=RTke1tQztpQ Acesso em: 26 out. 2016 . http://www.helenakatz.pro.br/midia/helenakatz21319549070.pdf Acesso em: 26 out. 2016.

${ }^{131}$ Tradução a partir do original: "Material may suggest what sort of process it should be run through (content suggests form), and processes may suggest what sort of material should be run through them (form suggests content)". 
música, parecem seguir a utilização de uma defasagem gradual de uma mesma ideia sonora, com variações de velocidades nas frases de movimentos que vão se desdobrando e se alterando por introduções discretas. Elas são promovidas a cada novo elemento que, aos poucos, é introduzido, até que predomine, originando uma nova forma de sequência. Os movimentos são simples, mas desenvolvidos de modo complexo por meio da repetição, continuidade, mudanças graduais e acúmulo.

Ademais, esse tempo musical se entrecruza e se sobrepõe às temporalidades da memória trabalhadas pelas dançarinas, como afirma Keersmaeker: "tenho uma profunda convicção de que o corpo questiona a memória das experiências humanas e de que a dança pode tornar as ideias abstratas bem concretas". ${ }^{132}$

Com a apropriação física dos movimentos executados pelas dançarinas em frases coreográficas com máxima precisão que se repetem e se desorganizam nas sucessões de movimentos e encadeamentos das sequências, o uníssono trabalhado por Keersmaeker se concretiza por "um ato de estar junto em um jogo de escuta e afirmação de si, permite a autonomia de um bem comum como a convivência com outros intérpretes"133 (FONTAINE, 2004, p. 190).

O uníssono permite o compartilhamento da textura particular da presença individual de cada bailarino e da presença coletiva em uma mesma cena. Ou, seja uníssono expõe a oposição grupo/indivíduo: se, por um lado, é acordo de compartilhamento de elementos comuns, por outro é diferenciação pelos sinais que cada um apresenta de acordo com sua necessidade. Diferenças singulares apenas percebidas na realização simultânea de um mesmo movimento em um espaçotempo.

Ao mesmo tempo em que esse material espaçotemporal apresenta elementos comuns compartilhados em grupo, o uníssono manifesta diferenciações e necessidades individuais como, por exemplo, o cansaço e a fadiga. Um dos exemplos dessa diferenciação individual que pode aparecer no compartilhamento de elementos comuns em grupo é o sinal de fadiga. Ele denota uma sensação causada pelo esforço continuado e repetitivo de um trabalho intenso, uma insistência e obstinação em questionar, refletir, observar e imaginar, a fadiga exprime a abertura de um questionamento e corresponde a uma necessidade.

\footnotetext{
${ }^{132}$ Entrevista à Helena Katz no Jornal O Estado de São Paulo. Data: 25/10/2011 Disponível em: http://www.helenakatz.pro.br Acesso em: 26 out. 2016.

${ }^{133}$ Tradução nossa a partir do original: "L'unisson, qui est ici la règle, permet l'autonomie de chacune tout autant que sa connivence avec les autre interprètes".
} 
A fadiga, que também indica duração temporal, é uma necessidade que demanda um estado de "repouso", aqui compreendido como "um direito do pensamento; [...] um dos elementos do devir [...] senti-lo no próprio nível da realidade temporal que dá fundamento à nossa consciência e à nossa pessoa" (BACHELARD, 1998, p. 5). Ela é um exemplo de diferenciação de necessidades implicada no uníssono, por exemplo, e colabora para que observemos como um parâmetro temporal pode se desdobrar em uma outra percepção temporal. Outro exemplo é o da fadiga que pode gerar contemplação. "A partir de nossas contemplações, definem-se todos os nossos ritmos, nossas reservas, nossos tempos de reações, os mil entrelaçamentos, os presentes e as fadigas que nos compõem" (DELEUZE, 1998, p. 138). A contemplação composta pela fadiga se configura como uma necessidade que carrega diferenças em um uníssono. $O$ compartilhamento coletivo de uma ação em um mesmo espaçotempo da cena, realizado de modo simultâneo pelo uníssono, desdobra outras noções temporais que o perturbam, como a sensação de fadiga. Trata-se apenas de um exemplo, porque há infinitas percepções temporais implicadas em cada parâmetro temporal do movimento. 
4.6 Parâmetros temporais do movimento no âmbito de curso de dança

Explorar os parâmetros temporais do movimento envolve variados aspectos, que podem ser estudados na construção de um espetáculo, numa prática de dança e também no contexto de um curso de dança. O estudo desses parâmetros se desdobra com funções e sentidos específicos em cada uma dessas atividades. Ou seja, o estudo dos parâmetros temporais do movimento se realiza de modo diferente para a concepção de uma obra artística e para a elaboração de um curso de dança.

Além disso, o estudo dos parâmetros temporais do movimento, como, por exemplo, em uma sequência coreográfica num curso de dança, é diferente dos procedimentos temporais que estruturam uma obra. Os procedimentos temporais que combinam diversos elementos na concepção de uma dramaturgia são fundamentalmente importantes porque eles dizem respeito não apenas ao movimento dançado, mas também ao modo de organização de todo o conjunto do espetáculo. Segundo Fontaine (2017), "é o procedimento que modifica fundamentalmente toda a concepção" (Informação verbal) ${ }^{134}$. Por exemplo, "em Cunninhgam é o procedimento do acaso que irá determinar a ordem das sequências", ou seja, é o procedimento temporal do acaso que orientará a combinação de uma coisa a outra.

Contudo, na elaboração de um curso de dança, o enfoque do estudo do movimento dançado sofre um outro olhar, dirigido à abordagem dos parâmetros temporais do movimento. Com esse entendimento, uma outra perspectiva de temporalidades é tangenciada aqui, sob o viés da elaboração para um curso de dança.

Abordamos, nesse momento, o estudo de parâmetros temporais do movimento observado em dois cursos de dança experienciados por mim durante a presente pesquisa de doutorado. Trata-se de dois cursos práticos de dança contemporânea dos quais participei como orientadora artística em São Paulo, e também de dois ateliês de dança de que participei como aluna, com o estágio de doutorado-sanduíche realizado na França. Esses últimos ocorreram sob a

\footnotetext{
134 "comme en Cunningham quand il utilise le hasard pour déterminer l'ordre de séquence [...] c'est le procède que change fondamentalement".
} 
orientação das coreógrafas, dançarinas e professoras Emmanuelle Huynh e Geisha Fontaine.

Além de cada atividade artística envolver um estudo específico dos parâmetros temporais do movimento, quando os pensamos para um curso, diversas variações e elementos novos intervêm no processo. Por exemplo, se eles são pensados para uma única sequência coreográfica, se seu estudo se dará na transição de um movimento, se eles estão implicados em um movimento curto ou longo, se este apresenta acentos; o que queremos dizer é que há diversos elementos, enfim, que interferem nos parâmetros trabalhados em cada processo.

Os cursos de dança orientados por mim durante a pesquisa tiveram como objetivo abordar e combinar diferentes parâmetros temporais, a fim de estudar a exploração do movimento. As ações se compunham por um aquecimento inicial, com dinâmicas que possibilitavam o reconhecimento do corpo em seu estado presente, trabalhando a percepção da gravidade e do fluxo interno do corpo. Além disso, exercitei a composição de sequências coreográficas, a fim de trabalhar a repetição, a memória, o uníssono e os jogos de velocidade.

Muitas das informações abordadas nesses cursos partiram também de conhecimentos e informações que obtive com diversos professores e coreógrafos que considero marcantes em meus estudos práticos de dança. Entre eles, estão: Cristina Salmistraro, Adriana Grechi, Zélia Monteiro, David Zambrano, Tica Lemos, Lu Favoretto, Key Sawao, Ricardo lazzetta, Liliane Benevento. Também contaram para essas experiências os conhecimentos que adquiri como professora, desde o período em que comecei a dar aulas de dança, em 2005.

Os cursos em que busquei investigar os parâmetros temporais no âmbito pedagógico aconteceram pelo Programa Vocacional, no qual atuei pela quarta vez como artista orientadora de dança, durante o período de abril a julho de 2017 . Houve duas turmas: a primeira, com 12 integrantes, no Teatro Municipal de Santo Amaro o Teatro Paulo Eiró, para estudantes de dança e teatro, jovens e adultos entre 17 a 40 anos; a segunda foi composta por 8 integrantes, com faixa etária entre 25 a 70 anos, no Teatro Municipal da Vila Mariana - o Teatro João Caetano. Ambos os teatros localizam-se na cidade de São Paulo.

A proposta de orientação para as duas turmas partiu do interesse em pesquisar e explorar coletivamente os parâmetros temporais acima citados e noções temporais implicadas na elaboração do movimento, por meio de exercícios e 
dinâmicas individuais, em duplas e em grupos. A experiência com as duas turmas gerou dois diferentes processos de criação e possibilitou observar que as temporalidades acontecem pelo engajamento de relações interpessoais.

No Teatro Paulo Eiró, o processo geralmente acontecia por um aquecimento corporal inicial em roda com todos os participantes. Nele, individualmente, ainda que em uma disposição coletiva, era trabalhada uma série de alongamentos, autotoque, direções ósseas do corpo e exercícios de segmentação para o reconhecimento das possibilidades articulares de cada parte do corpo. Essas dinâmicas, além de implicarem uma consideração temporal específica da concentração e reconhecimento do próprio corpo no tempo presente das ações, também envolviam a percepção da gravidade, ao observar partes do corpo que podiam ceder com o peso. Isso também implicava a percepção de partes que não podiam ceder devido às tensões, restrições e possibilidades de cada corpo. Havia também a percepção do fluxo da respiração, em exercícios com poucas repetições de movimentos, realizados no chão para suas descobertas em diferentes camadas.

A exploração da percepção gravitacional do corpo viabiliza nuances de movimentação, instaura uma outra velocidade de ações e permite uma modificação do estado corporal em relação à chegada do aluno na sala de aula. Ela requer escuta, atenção, concentração e uma baixa de tonicidade muscular. Após a exploração dessa percepção, em ambas as turmas, surgiu a necessidade do fluxo, do deslocamento e de mudanças de velocidade.

O fluxo foi trabalhado por meio dos deslocamentos no espaço e de forma coletiva, com a exploração do chão em ações de empurrá-lo e alcançar o espaço, além de favorecer o estudo das transições espaciais, tanto entre níveis (baixo, médio, alto), quanto entre planos (frontal, sagital, transversal). O fluxo também foi trabalhado por jogos de velocidade que aguçam a prontidão, por exemplo, em duetos: começava-se com alguém indicando os tempos de pausa, de aceleração e de lentidão; outra pessoa deveria, então, seguir o ritmo de velocidade dado pelo parceiro, mas não era necessário o compartilhamento do mesmo movimento, do mesmo nível ou plano. O que contava no jogo era a aptidão para a sintonia do fluxo entre as duplas. Após a inversão de papéis de quem conduz e de quem é conduzido, o jogo acontecia pela percepção entre os dois corpos: não havia mais uma figura definida que indicasse um determinado tempo, as percepções temporais se realizavam pela escuta e atenção dirigidas tanto a si próprio quanto ao outro. 
Esse jogo temporal modificava toda a movimentação, além de propiciar a percepção de diferentes acentos. Essa dinâmica lidava com a autonomia, a apropriação do movimento dançado e a prontidão.

Os parâmetros temporais da repetição e da memória foram explorados por sequências coreográficas, frases e movimentos de antemão determinados, que, após um processo de repetição, sofriam o mesmo procedimento do jogo acima descrito. Nesse momento, no entanto, o jogo era realizado com todos os integrantes, e não mais em duplas. No trabalho com a sequência coreográfica, a repetição e o fluxo provocavam prazer nos movimentos operados pelos participantes; a repetição possibilitava o aprimoramento das transições, projeções, equilíbrios e variações de ritmo.

Durante o processo, lembro-me de ter solicitado a cada participante que trouxesse uma dinâmica para o grupo, uma proposta que, para ele, tivesse a ver com tempo. Algumas das práticas levantadas foram: jogo de histórias coletivo, exercícios de confiança e entrega do corpo ao outro, propostas de manipulação e dinâmicas que implicavam contagens.

Após a apresentação das propostas de cada integrante, solicitei a cada subgrupo uma seleção de dinâmicas realizadas durante o curso. Cada grupo compôs uma lista de dinâmicas consideradas interessantes e prazerosas. Após o exercício de seleção, cada grupo apontou as dinâmicas que, em sua perspectiva, promoviam prazer e se vinculavam ao tempo. Realizamos uma espécie de storyboard, um esboço ordenado e sequencial das práticas selecionadas para as apresentações entre os grupos. Discutimos transições de uma dinâmica à outra em um trabalho de ordenamento do que vinha antes e depois na estruturação das práticas, até elaborarmos uma estrutura que poderia ser compartilhada coletivamente.

$\mathrm{Na}$ apresentação aberta dessa estrutura final, fui surpreendida pelo rumo que tomou uma das cenas, na qual eram realizados contrapesos, explorados de forma frontal, lateral e dorsal por duetos. Ao final dessa exploração, operava-se o contrapeso de costas até que as pessoas sentassem no chão, apoiadas umas nas outras. Elas então deram uma pausa e começaram a conversar, de costas para o seu próprio parceiro, mas de frente para o parceiro do outro. A conversa coletiva foi uma surpresa: a partir de um roteiro de ações previamente combinado, os participantes improvisaram e vivenciaram o tempo da apresentação. Expandiram 
temporalidades na medida em que experienciaram as relações e configurações daquele momento, e desdobraram relações espaçotemporais de modo imprevisível.

Com a turma de dança do Teatro João Caetano, o processo foi totalmente diferente. Sendo o grupo composto em sua maioria por mulheres idosas, o trabalho com a gravidade e a exploração do movimento no chão não foi tão grande quanto com a turma do Paulo Eiró. O grupo do João Caetano apresentou mais o desejo de fluxo do que o da experimentação com a gravidade. Comecei a trabalhar com dinâmicas que envolviam a interação entre os integrantes. Solicitei a cada um que trouxesse uma música ou trecho de música que tivesse marcado algum momento de suas vidas.

Os participantes trouxeram as músicas e contaram um pouco algumas de suas memórias que os marcaram. A partir disso, começamos a pensar certos movimentos que correspondessem às memórias acordadas pela música escolhida. Uma integrante trouxe uma música que, para ela, remetia a alegrias de quando era pequena. Falou também sobre jogos infantis; outra trouxe a memória de um afeto, de um gesto de agradecimento; uma outra senhora ouvia a música selecionada enquanto costurava; já outra trouxe uma música que lhe remetia à ideia de nascimento, vida e morte de uma flor. Assim, o trabalho corporal se deu principalmente com a memória de cada gesto trazido por elas, explorando a intenção de cada movimento; se as ideias seriam melhor comunicadas de forma rápida ou lenta; se deslocamentos se faziam necessários; em quais níveis e planos eles trariam a intenção da lembrança da música; se era necessário acentos, enfim, tratou-se de um estudo que se deu por meio de solos. Entre um solo e outro, uma mesma sequência de movimentos, simples e curta, era compartilhada em uníssono por todos. Essa sequência permeava os solos e foi criada de forma coletiva. A construção se deu por um processo de acumulação, no qual cada pessoa sugeria um movimento, que, por sua vez, era somado a outro movimento sugerido anteriormente, e assim por diante. A sequência em uníssono feita pela repetição provocava ligação e constraste entre um solo e outro.

A memória trabalhada nas duas turmas gerou processos totalmente diferentes. No grupo do Paulo Eiró, ela foi explorada em frases coreográficas, em repetições e na construção de um vocabulário comum ao grupo, com o qual poderiam jogar. No grupo do João Caetano, a memória foi trabalhada pelas histórias de vida de cada integrante. $O$ fato de o número de participantes ser maior no Teatro 
Paulo Eiró também colaborou para a exploração do uníssono, que ressaltava a ideia de grupo. Essa ideia, contudo, não implicava uma massa homogênea. Por exemplo, em outra dinâmica do curso, trabalhamos diferentes modos de falar ao mesmo tempo em uníssono, mas cada um falava de uma forma: um de modo carinhoso, outro nervoso ou irritado; cada um apresentava, dentro do grupo, maneiras diferentes de falar as mesmas frases.

A velocidade acelerada foi relevante para o grupo de jovens e adultos do Paulo Eiró; no grupo majoritariamente de senhoras do João Caetano o dilatamento temporal teve mais relevância nas cenas construídas. Mesmo partindo dos mesmos parâmetros temporais, os dois grupos apresentaram configurações cênicas totalmente diferentes, de acordo com o processo que vivenciaram durante o curso. Mas o fato de um parâmetro temporal estar mais presente em um processo do que em outro também evidencia a diferença entre as dinâmicas. Por exemplo, na apresentação do grupo do João Caetano, a memória foi um parâmetro temporal relevante na estrutura organizada, já no Paulo Eiró, o parâmetro temporal do uníssono se evidenciou de forma proeminente. A exploração mais intensa de um certo parâmetro temporal no processo faz com que ele se evidencie não apenas como estratégia de estudo do movimento, mas também como criação cênica.

Outro exemplo de estudo temporal do movimento no âmbito de um curso de dança foi minha participação como aluna no ateliê orientado pela dançarina e coreógrafa francesa Emmanuelle Huynh, no Centre National de la Danse (CND), Pantin/França, no período de 13 a 15 de março de 2018. O ateliê de dança focou-se em procedimentos temporais do movimento, tais como a lentidão, a permeabilidade, a exploração de zonas de contato em duetos e a produção de imagens. A proposta consistia em conduzir o participante a revisitar o processo de criação da obra Étrangler le temps _ boléro 2 (1996), concebido pela coreógrafa e diretora francesa Odile Duboc (1941 - 2010) e interpretado pela própria Emmanuelle Huynh e por Boris Charmatz. A proposta do ateliê consistia em explorar o estender, o alongar, o aumentar, o dilatar e o distender o gesto no tempo, apoiando-se sobre a obra dirigida por Odile Duboc.

Essas ações temporais foram trabalhadas de modo coletivo. Por exemplo, através de dinâmicas compostas por duetos, em que um, de olhos fechados, era manipulado pelo outro, numa proposta de construção de imagens e formas. Quem era manipulado, de alguma forma, se via surpreendido por um movimento que não 
faria se não fosse pela intervenção direta do outro, que manipulava o seu corpo e o seu movimento.

Nesse workshop, as imagens assumiam uma forma de expressão reconhecível. Vale dizer que grande parte dos participantes do ateliê eram estudantes da Escola de Belas Artes de Paris, onde Huynh leciona, além de estudantes de dança e artes visuais da Paris 8 e do próprio CND.

Além da construção de formas de imagens trabalhadas de olhos fechados, a lentidão foi explorada no estudo do movimento por meio de sequências coreográficas. Os movimentos lentos trabalhados no workshop fazem parte da coreografia do espetáculo Étrangler le temps. Segundo Huynh, nessa obra, há uma obsessão pela lentidão de cada movimento, e isso foi explorado com Odile Duboc. Segundo Huynh, a lentidão produzia uma espécie de zoom em cada entrelaçamento do dueto, como uma lupa de aumento nos movimentos. Em uma conversa durante o ateliê, Huynh comenta que, no deslocamento temporal em relação à época da criação, ela percebe o quanto a lentidão, obcecadamente explorada naquele momento primeiro, parece ser rápido comparando com a observação dela atualmente, através do vídeo e ao refazer a coreografia (Informação verbal). ${ }^{135}$

O trabalho com as imagens promovido no workshop parecia lidar com formas reconhecidas da expressão humana. Essa experiência trouxe para a presente pesquisa a reflexão sobre imagem promovida pelo historiador de arte e teórico cultural alemão Aby Warburg (1866 - 1929). Ela ajuda a perceber que as imagens são tanto objetos materiais como formas de pensamento, modos de conceber e de pensar. Os estudos de Warburg se direcionam à expressão humana e à expressão gestual em uma perspectiva trans-histórica. Os estudos acerca das formas de expressão humana, em especial os da dimensão simbólica envolvida nessas formas de expressão e da memória que opera nos processos de transmissão e transformação, possibilitam pensar de que modo a expressão humana assume a forma de imagens. Segundo o autor, pensar por imagens faz parte da memória que se forma por redes de associações. A construção da memória envolve imagens nas quais vislumbramos uma sensação, um pensamento, uma ideia. Para Warburg, tanto a manifestação de sentimentos, desejos, paixões, temores e angústias, quanto a orientação em meio ao mundo em que se vive possuem uma linguagem gestual.

\footnotetext{
${ }^{135}$ Informação fornecida por Emmanuelle Huynh durante o ateliê "Étrangler le temps. Emmanuelle Huynh e Boris Charmatz", Centre National de la danse (CND), Pantin, França, 2018.
} 
O filósofo italiano Giorgio Agamben (2010) também contribui para essa reflexão. Segundo ele, a imagem mnemônica, auxiliar da memória, tem a capacidade de produzir movimento no corpo. A memória não é possível sem uma imagem, porque "a imagem mnemônica está sempre carregada de uma energia capaz de mover e perturbar o corpo" (p. 14). De acordo com ele, o elemento fundamental da dança não é mais o movimento, mas o tempo.

As temporalidades que possibilitam a criação de uma dança e também sua dramaturgia articulam as memórias, as experiências, as referências e as informações nas atualizações de um movimento. Para tratar da questão colocada pelo autor, "como pode uma imagem ser carregada de tempo?", Agamben (2010) cita o coreógrafo da metade do século XV, Domenico de Piacenza. Esse último enumera, em seu tratado De la arte di ballare et danzare, seis princípios fundamentais da arte: memória, métrica, agilidade, modo, espacialidade e fantasmas. Domenico denomina o fantasma, ou dançar por fantasmas, uma repentina apreensão entre dois movimentos: a medida e a memória de toda a série coreográfica. Para Domenico, a dança é uma operação regida pela memória, uma articulação dos fantasmas em uma série temporal organizada.

Outra experiência que permitiu o presente estudo acerca de temporalidades foi a pesquisa e os cursos práticos e teóricos orientados por Geisha Fontaine, na Universidade de Bordeaux. Em um dos cursos, que ocorreu no período de 6 a 14 de novembro de 2017, Fontaine trabalhou com atividades práticas, entre elas a construção de proposições cênicas elaboradas em grupos. O trabalho com as composições temporais partia de uma palavra selecionada pelo grupo. As composições eram primeiramente trabalhadas como uma ideia a ser desenvolvida pelo movimento dançado e pelo estudo de estrutura, tendo como base as elaborações e as mudanças do começo, meio e fim de cada composição coreográfica. Após esse estudo e a apresentação de uma estrutura selecionada pelo grupo, a orientação era mudar as ordens de disposição da composição: o que seria o meio viria para o começo e o começo seria apresentado como fim. Essas mudanças alteravam a movimentação, as transições e provocavam a reflexão sobre a própria ideia implicada no movimento.

Outras alterações eram também solicitadas em relação à diminuição da duração do tempo da composição, o que nos impelia a fazer um recorte da mesma ideia. Outra alteração era fazer de forma rápida, mas permanecendo na mesma 
duração, o que incitava a pensarmos nuances de velocidade para a ideia de movimento proposta. Todas as mudanças eram elaboradas e apresentadas para todos os grupos, que aportavam materiais tais como livros, textos, imagens, sons e outras referências. Esse processo era acompanhado de uma discussão sobre o porquê das escolhas das referências. Além disso, outra dinâmica também orientada em função do tempo foi elaborar e apresentar uma ideia coreográfica em 15 min, depois em 10 min, e depois em 5 min; após a apresentação, seria preciso alterar o que seria o começo, o meio e o fim da movimentação.

Observei em meu grupo de trabalho que o estudo de cada mudança entre o início, meio e fim de uma mesma estrutura modificava toda a composição. Isso porque cada mudança implicava um ritmo e um caos na estrutura. O processo colocava outros desafios, necessitava de outras transições, que, por sua vez, levavam a um novo desenvolvimento. Esse curso também me fez constatar, em minha pesquisa acerca de temporalidades, que a alternância, tanto dos elementos em uma ordem cronológica temporal, quanto de duração, transforma o modo de comunicar as ideias concebidas em uma proposição coreográfica inicial. Pensar sobre tempo e temporalidades no estudo da movimentação e em uma estruturação cênica desenvolve um processo de escolhas e de aprimoramento sobre o conteúdo e a forma da comunicação a partir do movimento. Percebemos também que o fator experiência é determinante nessas articulações temporais para a construção cênica.

A escolha de música e iluminação também era trabalhada pelos alunos. Os estudos da movimentação implicada em seus fatores temporais e da elaboração de uma estrutura de composição, baseada em mudanças de tempos e de temporalidades, traziam um olhar criterioso para a composição. Além disso, questionar as intenções e a ordem de cada movimentação, bem como questionar a estrutura como um todo, favorecia a comunicação da intenção do coreógrafo para o espectador, colaborando para que a ideia proposta fosse clara em suas diversas camadas. 


\section{Temporalidades: questionamentos de um presente imediato}

\subsection{Dimensão política de temporalidades em dança}

As temporalidades em dança envolvem uma dimensão política na medida em que os dados temporais criados em uma concepção artística se processam em relação ao ambiente, ao contexto histórico e sociocultural em que são elaborados. Considerando que as temporalidades em dança estão vinculadas ao contexto histórico ${ }^{136}$ e à cultura, abordamos neste capítulo certos aspectos sociopolíticos de temporalidades, observando como elas estão imbricadas em relações de poder e nas condições econômicas da dança.

O caráter relacional de temporalidades implica a conexão entre arte e política. Além de as temporalidades viabilizarem-se pela relação com o ambiente onde se processam, elas apresentam singularidades compostas pelo entrelaçamento de lógicas heterogêneas e de dissensos no compartilhamento de experiências comuns. Se as temporalidades portam singularidades e lógicas de dissenso, essas características envolvem certos elementos políticos, segundo os autores Jacques Racière e André Lepecki.

A conexão entre arte e política proposta pelo autor Jacques Rancière (2014) contribui para pensarmos certos aspectos políticos de temporalidades em dança. Para ele, a "política é assunto de sujeitos, ou melhor, de modos de subjetivação" ( $p$.

${ }^{136}$ Como exemplo de que as temporalidades envolvem uma dimensão política e artística de acordo com o contexto histórico e cultural, podemos observar novamente a obra Men Walking Down on the Side of a Building. Alinhados ao pensamento da Judson Church, ao questionar definições de dança, coreógrafos pós-modernos passam a interrogar-se sobre o tempo, o espaço e o corpo em dança, entrecruzando-a com outras artes e incluindo em sua criação jogos e ações simples como andar e correr. Segundo a autora Sally Banes (2002), "os coreógrafos pós-modernos propunham que uma dança era uma dança não por causa de seu conteúdo mas sim pelo seu contexto. Esta abertura da dança foi uma ruptura com a dança moderna. [...] Chamar uma dança de dança pela relação com seu ambiente (mais do que pelas suas qualidades internas de movimento ou de conteúdo) trazia uma mudança em termos da teoria da dança, alinhada com a arte contemporânea" (p. 47). Outro exemplo disso seria o trabalho Brevidades, que, em vez de lidar com o chão neutro de uma sala de espetáculo, lida com o chão do Largo da Batata, que sofreu um processo de higienização. Além disso, a obra parte de questionamentos acerca da demanda imperiosa de estarmos em constante produção. 
49). "Política não é, em primeiro lugar, exercício do poder ou luta pelo poder" (p. 59). Em vez de uma atividade política praticada pelo poder definido, em primeiro lugar, pelas leis e instituições, a política "reconfigura os âmbitos sensíveis nos quais se definem objetos comuns" (p. 59). São diversas singularidades que pensam o poder comum, porque temos, nos dias de hoje, não apenas a voz de um movimento, mas sim entrelaçamentos de lógicas heterogêneas que tentam pensar o poder comum inclusive nos momentos singulares.

Se as temporalidades correspondem ao processo de criação e organização de procedimentos espaçotemporais, elas envolvem qualidades temporais elaboradas de acordo com as experiências perceptivas, motoras e intelectuais de um corpo. Desse modo, elas envolvem modos de subjetivação. "Por subjetivação entenda-se a produção, por uma série de atos, de uma instância e de uma capacidade de enunciação [...] cuja identificação, portanto, vai de par com a reconfiguração do campo da experiência" (RANCIÈRE, 2018, p. 49).

Segundo o autor, "desde que as manifestações de massa não são mais chamadas pelos partidos e sindicatos mas sim por inúmeros micro-coletivos" ${ }^{137}$ (2017, p. 47), as palavras de ordem deram lugar a diversas formas heterogêneas que implicam o dissenso. O dissenso é percebido como uma valorização da diferença, ele está no cerne da atividade política ao produzir ruptura de hábitos e de comportamentos. Diferentemente do consenso, "que suprime todo cômputo dos nãocontados, toda parte dos sem-parte"138 (RANCIÈRE, 2014), o dissenso se constitui como um conflito de encontros heterogêneos; na contramão do entendimento que parte de uma identificação e linguagem de comunicação entre parceiros constituídos sobre objetos ou afins pertencentes.

A questão possibilita que compreendamos que as temporalidades heterogêneas no campo da dança não são formadas por uma hegemonia, ou consensos impostos, mas sim por singulares pensamentos e posições. Se as temporalidades são viabilizadas apenas de modo relacional, a dimensão política se

${ }^{137}$ Tradução nossa a partir do original: "Depuis que les manifestations de masse ne sont plus appelées par les partis et les syndicats mais par d'innombrables micro-coolectifs, les grandes banderoles et les mots d'ordre des avant-gardes ont cédé la place à ces multitudes de pancartes où chacun a risqué ses mots et éventuellement ses dessins."

138 Disponivel em: https://territoriosdefilosofia.wordpress.com/2014/10/19/o-dissenso-jacquesranciere/ Acesso em: 30 out.2018. 
revela porque as relações configuram intersubjetividades de uma época, não como seu reflexo, mas como produção de questionamentos.

Segundo Lepecki (2016), os diferentes pontos de vista implicam singularidades na medida em que a subjetividade é portadora de bifurcações e de atualizações que emergem de inquietações do olhar para problemas políticos, corporais, afetivos e sociais. De acordo com o autor, a singularidade em dança se apresenta como zona de eventos que visam apresentar um problema ou um conjunto de problemas, sem necessariamente almejar uma solução, mas sim gerar um movimento de problematizações (LEPECKI, 2016) ${ }^{139}$.

a palavra 'singularidade' é usada de forma precisa. Não é sinônimo de 'único', de 'particular', de 'singular', e menos de 'individual'. Em vez disso, singularidade é portadora de estranhezas como o filósofo de arte Huberman propõe. Como essencialmente co-extensiva com a estranheza, singularidades são sempre produtoras de multiplicidade, complexidade, bifurcações, e desvios imprevisíveis que implicam todas as dimensões do real. ${ }^{140}$ (LEPECKI, 2016, p. 6)

Temporalidades implicam singularidades pelas diferentes experiências.

Diferentemente do substantivo tempo, o próprio termo temporalidade se constitui como adjetivo, denotando qualidades. E a qualificação de algo sempre envolve um determinado ponto de vista, uma determinada percepção e uma subjetividade ${ }^{141}$ que encontram vias de especificação pelo sistema corporal coletivo.

A expressão temporalidade indica ainda provisoriedade (FERREIRA, 1972, pp. 1164 - 1165), mutabilidade e fluxibilidade (AZEVEDO, 2010, p. 41), o que denota especificidades, reconfigurações e transformações; ademais, sugere ainda

\footnotetext{
139 "I believe dance has such privileged critical position of analysis and resistance in regards neoliberal rationality, corporeality, and subjectivity. [...] In this sense, dance in the age of performance already expresses its singularity: to generate charged and vital problematic fields on which pressing and urgente political, corporeal, affective, and social problems are made visible and gather - not to find a solution, but to further the movement of probletization" (LEPECKI, 2016, p. 8).

${ }^{140}$ Tradução nossa a partir do original: "Throughout this book the word 'singularity' is used in a very precise way. It is not synonymous to the 'unique', to the 'particular', to the 'singular', and even lesse to the 'individual'. Rather, singularity is 'irreducible, and therefore, a bearer of strangeness' as philosopher of art Georges Didi-Huberman proposes (2009, p.81, tradução minha). As essentially coextensive with strangeness, singularities are always producers of 'multiplicity', 'complexity', 'bifurcations', and unanticipated swerves that implicate all the dimensions of the real".

${ }^{141}$ Os filósofos Felix Guattari e Suelly Rolnik (1996) propõem pensar a subjetividade como uma trama de fluxos construídos por um indivíduo a partir de seus processos singulares, subjetividade reconhecida num sistema corporal coletivo. "A subjetividade não se situa no campo individual, seu campo é o de todos os processos de produção social e material" (p. 28). A produção de subjetividade é "uma concepção que não tem nada a ver com postular instâncias intrapsíquicas ou de individuação" (p. 29), "subjetividade que se singulariza e que encontra as vias de sua especificação" (p. 45).
} 
elementos implicados no corpo e nas experiências que ele atualiza no compartilhamento de situações comuns.

As temporalidades se constituem por atualizações, transformações e imprevisibilidades; trata-se de uma noção temporal de constantes requalificações, ao gerar questionamentos pelo e no compartilhamento de situações comuns.

O corpo no ambiente dança sempre está em vias de qualificar um processo artístico para que suas especificações possam emergir e ganhar forma. Além disso, há também constantes requalificações ao longo da profissão de um artista de dança, contínuas reconfigurações de experiências comuns, ou seja, transformações que acontecem no fazer em dança. Quando falamos em transformação, isso implica um fator temporal.

As singularidades produzem diferenças, envolvem necessidades de deslocamentos e constantes atualizações da percepção espaçotemporal no compartilhamento de situações comuns. Esse compartilhamento implica singularidades temporais de um corpo, porque é a partir de compartilhamentos com o outro que percebemos e qualificamos uma determinada maneira de agir e de construir uma dança.

Outro aspecto de temporalidades em sua dimensão política é a de que elas implicam uma relação espaçotemporal em dança que difere de uma percepção temporal linear do tempo, em um espaço mensurável Euclidiano. Diferentemente da percepção do corpo como um móvel evoluindo no espaço cartesiano, diversas relações espaçotemporais são construídas, pois o corpo do qual tratamos "transforma o tempo objetivo dos relógios" (GIL, 2001).

Para o filósofo José Gil (2001), as noções temporais que um corpo articula, não acontecem numa extensão objetiva, numa profundidade mensurável ou no espaço de um corpo fixo e autônomo, mas são promovidas por um dilatamento temporal construído segundo as espacialidades de cada corpo. Desse modo, uma temporalidade da dilatação acontece pelos alargamentos dos espaços do corpo.

A relação entre o corpo cênico e o corpo do espectador, pensada como um encontro, como propõe José Gil (2013, p. 128), "expande potências de agir", porque mobiliza uma força da diferença por outros afetos, espaços, ritmos e plasticidades temporais internas. Nesse encontro, outras profundidades acontecem no "espaço do corpo que nasce da energia” (GIL, 2001, p. 66). Ou seja, essa relação implica 
noções temporais que vão além de uma percepção linear num espaço mensurável e num tempo cronológico.

As temporalidades acontecem nas provisoriedades, imprevisibilidades e reconfigurações das ações corporais num processo de criação e apresentação de uma dança, bem como nas percepções cruzadas do espectador e do dançarino. São temporalidades que diferem do tempo objetivo definido de antemão, implicado no plano da coreografia que surge a priori por uma formatação gráfica ${ }^{142}$. Segundo Lepecki (2010), essa formatação lida com um plano bidimensional, com a percepção de um espaço branco, neutro, chato e livre de rachaduras, e com a ilusão de um lugar perfeito, controlado e sem imprevistos.

Essa coreografia, que utiliza o espaço horizontal por desenhos traçados no chão, implicada no balé de corte em um tempo determinado previamente, sucessivo e linear, por passos previamente determinados, implica também uma dimensão política. Isto é, ela apresenta uma condição na qual "encontrava-se preservada a razão política de perpetuar, como algo incontestável, a relação de dominância da realeza sobre a sociedade" (HERCOLES, 2005, p. 50).

De lá para cá, muitas outras abordagens de espaço e de tempo emergiram, ao longo da história da dança. Não temos a intenção de realizar aqui uma análise historiográfica, contudo, podemos observar que a dimensão política em dança se apresenta por abordagens correspondentes a cada época, aos saberes e conhecimentos de certos momentos da história. Nesse sentido, quando tratamos de temporalidades, de questões temporais em dança percebidas nos dias de hoje e em um contexto ocidental, invariavelmente isso implica uma perspectiva política, porque traz questionamentos de nosso presente imediato no ambiente contemporâneo.

Abordamos, no capítulo 2, em "Dramaturgia que transborda os marcos de um texto dramático", a expansão de temporalidades atualmente percebidas em corporalidades entrelaçadas, em procedimentos temporais que entrecruzam diferentes formatos e linguagens artísticas numa hibridização das artes. Isso, por si, também revela um aspecto político. Segundo Rancière, "uma das características da

142 Lepecki (2010) se refere ao método proposto por Feuillet no qual o "contato com o mundo é reduzido a um ponto geométrico e cuja trajetória desenha uma linha de deslocamento no plano folha/chão" (p. 14). Esse plano de composição, além de denotar um tempo determinado, indica ainda um tempo da linearidade. A notação coreográfica estabelecida na obra de Feuillet é "seguir um caminho traçado com arte". Ele explicita que denomina caminho a "linha sobre a qual se dança" (MONTEIRO, 1998, p. 340), segundo a carta 13 de Noverre. 
arte atualmente é o estabelecimento de conexões transversais entre as práticas normalmente separadas" ${ }^{143}$ (2017, p. 49).

De acordo com o autor, a arte se aproxima da política na medida em que ambas lidam com materiais e formas heterogêneas, que atravessam fronteiras entre atividades e campos. Em vez de manejar unidades constituídas como classes sociais ou artes definidas,

o que aproxima atualmente a arte da política, é se interessar mais por palavras e imagens, pelos movimentos, pelos tempos e pelos espaços e as combinações diversas e moventes desses elementos (performance, encenação, instalação, exposição, etc.) do que uma renovação interna das artes constituídas. ${ }^{144}$ (RANCIĖRE, p. 48)

As práticas artísticas do corpo em dança implicam uma dimensão sensória da experiência que se apropria de fatores da vida em comunidade. Para Rancière

se existe uma especificidade de nosso presente é a atenção às transformações das formas de vida e um mundo da arte que é marcado pelo cruzamento de tipos de expressão e montagem de seus elementos mais do que pelas dinâmicas próprias das artes estabelecidas. $^{145}(2017$, p. 49$)$

A dança se conecta a fatores históricos, culturais, sociais e políticos na medida em que as percepções emergem de nossa experiência corporal. Essa experiência ocorre em "uma relação espaço temporal borrada da qual o final diferentemente retorna para o seu começo" (CASPÃO, 2010, p. 128). Isso não quer dizer que o passado de um corpo desapareça - aliás, o corpo precisa das informações incorporadas para sobreviver. Mas as atualizações promovem novas configurações que vão continuamente interpelando nosso presente.

Segundo Cvejic (2015), a percepção da mudança não está emaranhada com o passado que desaparece, mas, em vez disso, é unida ao passado que persiste no

\footnotetext{
${ }^{143}$ Tradução nossa a partir do original: "On pourrait aller plus loin et dire que l'un des caractères dominants de l'art d'aujourd'hui, c'est l'établissement de liens transversaux entre des pratiques normalmente séparées."

${ }^{144}$ Tradução nossa a partir do original: "Ce qui rapproche aujourd'hui l'art de la politique, c'est de s'intéresser plus aux mots et aux images, aux mouvements, aux temps et aux espaces et aux combinaisons diverses et mouvantes de ces éléments (performance, mise en scène, installation, exposition, etc.) qu'à un renouvellement interne des arts constitués."

${ }^{145}$ Tradução a partir do original: "S'il ya une spécificité de notre présent, elle est dans cem ode de voisinage indécisis entre le militantisme politique, l'attention aux transformations des formes de vie et un monde de l'art qui est marque par le croisement des types d'expression et le montage de leurs éléments plus que par des dynamiques propres aux arts constituídas."
} 
presente. A mudança como um desaparecimento ou oposição binária entre presença/ausência e vida/morte não ajuda a pensarmos a temporalidade porque, de acordo com Cvejic, uma concepção temporal que lida com a mudança como desaparecimento "não engaja os vários registros temporais que reformulariam a temporalidade como um processo" (CVEJIC, 2015, p. 199) ${ }^{146}$.

A dança lida com uma condensação, onde ocorre a tensão entre o que foi, o que poderia ser e o que será necessário para uma decisão imediata. Essa concepção permite pensarmos a dança sob diferentes prismas temporais, como em temporalidades dilatadas que agem na articulação do pensamento na medida em que convocam, no presente, a memória e a história de vida de um corpo.

Para a autora Véronique Fabbri ${ }^{147}$, "o trabalho sobre o desaparecimento na dança não é um trabalho sobre o evanescente do movimento, mas sobre a temporalidade da repetição" 148 (FABBRI, 2007, p. 167). O pensamento apresentado por uma proposição de dança, as memórias, os traços e as repetições dessa experiência produzem um desenvolvimento de ideias e ressonâncias corporais que são articuladas na trajetória de um dançarino ou coreógrafo.

Se a dança contemporânea ${ }^{149}$ lida com referências culturais, institucionais e sociais que marcam o ambiente no qual ela se desenvolve (FRIMAT, 2010, p. 17) ${ }^{150}$, isso traz uma certa perspectiva política, porque implica questionamentos artísticos diversos, construídos e viabilizados em relação a um mercado cultural.

${ }^{146}$ Segundo Cvejic (2015) "a conception of time still revolves around the event as an act, around change as disappearance, and around the binary oppositions of presence/abscence and life/death, it doesn'nt yet engage with various 'temporal registers' that would recast the temporality of performance through another kind of process, divorced from the anthropocentric view of human life. For a processual concept of time in performancewhereby the perception of change isn't entangled with the past that disappears, but that is instead joined eith the past that persists in the present (because the performances construct a continuum of the past into the present, implicating its deferred action into the future)" (p. 199).

${ }^{147}$ Véronique Fabbri é professora de filosofia contemporânea da Paris VIII, suas pesquisas versam sobre dança contemporânea e escritura filosófica.

148 Tradução nossa a partir do original: "Le travail sur la disparition en danse n'est pas un travail sur l'évanescence du mouvement, mais sur la temporalité de la répétition : cette temporalité se maintient dans la présentation du travail final". (2007, p. 167).

${ }^{149}$ Para a autora François Frimat, "o contemporâneo refere-se ao que me preocupa e define os contornos não do atual, mas de uma atualidade que se dá como problemática, considerando-a para além do que me diverte e que está sempre a se resolver". (FRIMAT, 2010, p. 9). Trad. nossa a partir do original: "Le contemporain renvoie à ce qui me concerne et définit les contours non de l'actuel mais d'une actualité qui se donne comme problemátique à considerer par-delà ce qui m'en divertit et toujours à resoudre."

150 Tradução nossa a partir do original : "Décrire l'intention chorégraphique à l'oeuvre dans un corpus d'oeuvres engagées vis-à-vis de l'art contemporain par refus, adhésion ou défi sera donc notre première tache. Par amplification, cet engagement a aussi une dimension politique tant il travaille les repères culturels, institutionnels et sociaux qui marquent l'environnement dans lequel il se déploie." 
De acordo com as autoras Janine Rannou e lonel Roharik (2006), "a atividade profissional dos artistas da dança é um ofício de engajamentos" ${ }^{\text {151 }}$ (p. 15). Elas sublinham que esse ofício, ao mesmo tempo que supõe um comprometimento inscrito na duração da vida profissional de um artista, também envolve diversas situações econômicas que se caracterizam, para um grande número de artistas, por sua brevidade. Para as autoras, o trabalho no campo da dança se baseia em um senso de urgência e em uma relação com o tempo presente exacerbado, tanto pela sua vida pessoal, quanto profissional. Isso traz um presente de permanente tensão entre o fortalecimento de posicionamentos em redes profissionais, preparações de sua dança e preocupações com o devir após a dança, envolvendo constantes escolhas profissionais e artísticas.

De todo modo, temporalidades em dança apresentam um duplo viés que carrega implicações políticas no interior da prática. Por um lado, ela assimila um presente que é efêmero. Por outro, apresenta informações que não se constituem apenas de constantes agoras, porque o presente da dança incorpora memórias, informações históricas e compartilhamentos de situações comuns. A temporalidade do efêmero, além de ser uma característica de elaboração do movimento dançado, implica estratégias artísticas singulares e emergentes que se alinham com o mercado artístico contemporâneo e com os métodos de produção do fazer em dança.

A palavra temporalidades envolve uma dimensão efêmera da dança, que geralmente se passa em uma apresentação. Com muita sorte, ela se estende por uma temporada, que pode durar mais de um mês.

A autora Geisha Fontaine (2004) lembra que a palavra efêmero, de origem grega, significa "apenas por um dia". Ao observar a dimensão efêmera, passageira e evanescente da dança, Fontaine afirma que ela não se inscreve no valor de mercado da durabilidade. Segundo ela, o corpo do bailarino e sua capacidade de movimento se veem tanto sob sua condição mortal, quanto implicados no desejo de duração da obra. Se, por um lado, o valor de mercado está ligado à produção do durável, do permanente, do imortal, por outro, a dimensão efêmera da dança se processa justamente por essa qualidade temporal.

\footnotetext{
$\overline{151}$ Tradução nossa a partir do original: "Danseur, c'est un métier d'engagement".
} 
Segundo ela, o desejo de eternidade, expresso pela busca de uma permanência ou de uma durabilidade do trabalho artístico, implica a vontade de permanência (imortalidade e eternidade). Isso traz a questão da legitimidade, do poder e da força. Fontaine (2004) ainda lembra que todo poder político envolve a construção de monumentos, feitos para durar e marcar o futuro. Nessa situação econômica da arte e da economia cultural, certos quadros de pintura, por exemplo, atingem investimentos consideráveis, em contraste com um valor frágil de mercado, do instante único da representação realizada pelos profissionais das artes cênicas, que se produzem graças a apoios e subvenções. Essa característica efêmera se distingue, por exemplo, da permanência de um CD musical, de um texto dramatúrgico, de um quadro ou pintura. Uma obra de dança se manifesta em uma duração delimitada no momento presente do encontro entre o espectador e o dançarino.

"Se a arte tende a produzir o imortal, a dança se constrói com o corpo mortal na sua capacidade de movimento. O corpo do dançarino é apresentado sob esta dupla injunção"152 (FONTAINE, 2004, p. 23). Embora seja comum a utilização de registros, como cadernos, fotos, vídeos e outros documentos preparados em um processo artístico, eles diferem do próprio movimento dançado.

Segundo Lepecki (2016), um dos elementos constitutivos da dança que a aproxima dos problemas políticos e subjetivos é a efemeridade. Isso porque a "efemeridade também exige uma rearticulação de vetores temporais, uma vez que o efêmero não é o que acaba de passar, mas o que, por passar, assombra a cada segundo o presente como um potencial para o futuro" ${ }^{153}(2016$, p. 15).

\begin{abstract}
A efemeridade impregna os interstícios do tempo com uma dimensão messiânica, graças à qual o próprio passado revela ser não simplesmente feito de tudo o que se passou no tempo presente, mas como uma dimensão da potencialidade da matéria profundamente tecida na estrutura do futuro. ${ }^{154}$ (LEPECKI, 2016, p. 15)
\end{abstract}

\footnotetext{
${ }^{152}$ Tradução nossa a partir do original: "Si l'art tend à produire de l'immortel, la danse se construit avec le corps mortel dans sa capacité de mouvement. Le corps du danseur est mis en scène sous cette double injonction".

${ }^{153}$ Tradução nossa a partir do original: "Ephemerality also begs for a rearticulation of temporal vectors, since the ephemeral is not what has just passed (away), but that which, because it passes, haunts every second of the present with its potential return".

${ }^{154}$ Tradução nossa a partir do original: "Ephemerality impregnates the interstices of time with a messianic dimension, thanks to which the past reveals itself to be not simply made of whatever is gone from present time, but as a dimension of potentiality of matter deeply woven into the fabric of the future. Ephemerality is already dance'safterlife, the promise of an incalculable return without profit".
} 
Para o autor, a efemeridade implica as potencialidades e emergências da criação. O efêmero, dessa perspectiva, não é apreendido como uma noção temporal voltada para a circulação de uma política econômica de fluxos. O entendimento de temporalidade proposto por Lepecki traz a discussão acerca do efêmero que está longe de regimes de mercantilização e fetichização de objetos tangíveis. $O$ autor sugere um entendimento de efêmero que se direciona à subversão de uma lógica hegemônica neoliberal, com o efêmero percebido pelo questionamento, diferenças, estranhezas e mudanças.

O efêmero em dança não se realiza de maneira previsível, em uma continuidade permanente, pois ele "não é o que passa, mas o que não ancora: é puro rizoma, sem porto-seguro nem fundações. O efêmero consiste em acolher o espírito da onda, em aceitar o fluindo e o flutuante" (LINS, 2008, p. 53). O efêmero em dança não é o que se passa como um movimento transitório no espaço, mas o que provoca e implica mudanças.

Quando Louppe (2012) afirma que a "percepção do movimento dançado como efêmero nasce da experiência do sujeito que dança" (p. 164), podemos observar que a temporalidade do efêmero se processa pelas incessantes mutações e atualizações do movimento. Para ela, a dimensão efêmera da dança acontece na experiência do movimento, que pode surpreender até mesmo o próprio corpo dançante.

De acordo com ela, a característica efêmera da dança acontece nas várias percepções cruzadas que se agitam entre corpos e olhares, tanto nas relações coreográficas, quanto no que concerne ao espectador (LOUPPE, 2012, p. 164). A criação no instante presente da elaboração do movimento será de fato nãopermanente: em outro momento, será já outro movimento, o corpo vai se atualizar em outra circunstância espaçotemporal.

Se, por um lado, essas elaborações realizadas em um processo de trabalho aparecem de modo efêmero apenas no momento de sua apresentação (LEPECKI, 2006) ${ }^{155}$, por outro, o processo dá a ver temporalidades como produção de

\footnotetext{
${ }^{155}$ A partir da reflexão de At the Vanishing Point da autora Marcia Siegel, que sugere que a dança existe em um perpétuo (vanishing point), o pesquisador de dança Andre Lepecki ${ }^{155}$, em seu livro, Exhausting Dance (2006), desdobra a reflexão de que, no momento da materialização de uma criação, essa já se foi. Todas as preparações e elaborações para um evento desaparecem no ato de sua concretização.
} 
diferenças, material potencial e emergente de transformação social. Isso implica percebermos as mudanças desejáveis e possíveis na própria experiência.

Segundo Fontaine (2004), se a dança "é uma estética não separada da política, se ela é exploração dos tempos presentes, a dança tem uma chance que é precisamente o risco" (2004, p. 91). De acordo com ela, "o coreógrafo não está na eternidade, ele se expõe no duplo movimento de abandono e desafio" 156 (FONTAINE, 2004, p. 36), nas abordagens técnicas e desafios coreográficos que definem sua dança. Isso porque a dança lida com o material finito do corpo humano. Desse modo, Fontaine afirma: "busco simplesmente seguir o caminho da dança, de sua singularidade: sua insistência sobre o transitório, a aventura dos corpos que se concentram sobre o que vai desaparecer" (FONTAINE, 2012, p. 29).

Além das características do provisório, do efêmero e da singularidade implicadas na temporalidade, sua qualidade relacional e processual tende a valorizar a dança como uma experiência. Isso se oporia à ideia da dança como produto a ser colocado na prateleira de um mercado e utilizada como exercício de poder pelo mercado da arte.

A dança inserida no mercado do espetáculo como um produto é frequentemente pautada segundo critérios da novidade. O novo e o velho são categorias que influenciam no valor do "produto" de um trabalho de dança. "A política da arte é assim marcada por uma estranha esquizofrenia. Artistas e críticos nos convidam a situar o pensamento e as práticas da arte num contexto sempre novo" (RANCIĖRE, 2014, p. 52).

De acordo com Louppe (2007), "se opor a esse valor de mercado faz parte das estratégias dos coreógrafos atualmente" ${ }^{157}$ (p. 17). Para ela, a dança contemporânea tem como valores fundamentais a primazia da experiência sobre o produto e do processo sobre o espetáculo.

Além de o mercado cultural se pautar por critérios como o novo e o velho, ele também envolve uma constante atitude projetiva de um futuro planejado, mas ainda não vivido. A autora Bojana Kunst $(2010)^{158}$ sugere que o lugar contemporâneo da

\footnotetext{
${ }^{156}$ Tradução nossa a partir do original: "Le chorégraphe n'est pas dans l'éternité; au contraire, il est au plus prés de l'écoulement du temps, il s'y expose dans le double mouvement de l'abandon et du défi" (p. 36).

${ }^{157}$ Tradução nossa a partir do original: "S'opposer à cette valeur marchande du dernier produit fait partie des stratégies de chorégraphes d'aujourd'hui".

158 Disponível em: http://www.manifestajournal.org/issues/regret-and-other-back-pages/projecthorizon-temporality-making\# Acesso em: 19 mai. 2017.
} 
arte implica um compartilhamento comum das condições sociais e econômicas que estão diretamente relacionadas ao trabalho artístico. Kunst parte da palavra projeto para abordar a atitude projetiva - sempre, evidentemente, futura - que um artista desenvolve ou irá desenvolver em um processo colaborativo. O labor do artista envolve a realização de constantes procedimentos que visam tornar realizável o que se projetou, almejando, por exemplo, mostras, residências, editais, candidaturas, concursos etc. Trata-se de estruturas que incluem submissão de propostas, atividades que, segundo Kunst, fazem progredir uma corrida no tempo homogêneo para sobreviver no mercado da arte da dança.

Ao mesmo tempo que singularidades heterogêneas se apresentam pelas diferentes e emergentes propostas artísticas, por outro, envolvem também realidades comuns vividas pela comunidade profissional de um dançarino. Por um lado, se há o tempo projetivo que culmina no desejo incessante por um novo projeto, uma especulação sobre o planejado - porém ainda não vivido - futuro (KUNST, 2017) ${ }^{159}$, por outro, esse tempo projetivo implicado em projetos possibilita a viabilização da sobrevivência de artistas no campo de trabalho.

Além desse futuro, que inclui a ansiedade pela busca de sobrevivência do próprio trabalho, Bojana Kunst (2015) nos apresenta outras condições implicadas no trabalho no contexto do capitalismo contemporâneo. Exemplos disso são o dinamismo, estar ativo, participativo, pronto para oposições, gerar ideias novas, prestar atenção nos contextos e nas constantes reflexões acerca dos métodos de produção. Para ela, esses elementos se incorporam como valor de mercado. "O desejo por mudanças e constantes reflexões sobre condições criativas são forças motrizes do desenvolvimento do mundo pós industrial, marcado pela necessidade de revolucionar constantemente os métodos de produção" (KUNST, 2015, p. 6). A criatividade e a imaginação, que são ações tão caras ao trabalho do artista, assumem também valor na produção, são fundamentais em dança, mas também se apresentam como um objeto culturalmente negociável.

Bojana propõe uma "temporalidade que se torna uma imanência consciente. [...] Uma experiência do tempo que, expandido, possibilita as estratégias para

159 Disponivel em: http://www.manifestajournal.org/issues/regret-and-other-back-pages/projecthorizon-temporality-making\# Manifesta journal (Jornal internacional que aborda práticas e teorias contemporâneas). Edição 16. Acesso em: 19 mai. 2017. 
organizar a difusão da percepção em relação ao espectador" ${ }^{160}$ (KUNST, 2010, p. $5)^{161}$. Quando a autora afirma que "a temporalidade está no cerne da produção da diferença. É o material da mudança social e estética" (KUNST, 2012, p. 3), a ideia de temporalidades é percebida por questionamentos e proposições artísticas emergentes. Isso difere do pensamento sobre "o movimento no capitalismo, que está intimamente relacionado com a progressão do tempo e do estabelecimento do novo"162 (KUNST, 2012, p. 3).

O labor em dança não está desvinculado dos modos produção e veiculação de um trabalho. Embora não inscrita no mercado da durabilidade, a dança envolve uma pesquisa constante de recursos e estratégias para continuar sendo cada vez mais organizada por coletivos de lógicas heterogêneas. Isso porque a dança está implicada em um mercado econômico cultural, mesmo que alternativo. O fazer em dança não está desvinculado dos modos de produção porque envolve uma prática de encontros com outros artistas e técnicos, cursos, pesquisa, veiculação de um trabalho, vias de apresentação e difusão e outras atividades de engajamento com o ofício da profissão. Se os dados temporais são determinantes como processo de organização, de estruturação e de coerência de uma criação em dança, isso conduz a fazer planos coreográficos, prática em estúdio, ou seja, esse processo implica uma busca constante de recursos para sobreviver no campo coreográfico.

\footnotetext{
160 “Temporality becomes an imanent, 'conscious' element of the performance, by means of which theatre refers to its own process. The experience of time expansion and, consequently, the various strategies for organizing the spectadator's diffused perception are common characteristics of contemporary performance."

161 Disponível em: https://kunstbody.wordpress.com/2010/12/10/how-time-can-dispossess-onduration-and-movement-in-contemporary-performance/ Acesso em: 19.mai.2017.

162 Tradução nossa a partir do original: "I use the case of contemporary dance to write about the central role of movement in capitalism, wich is closely related to the progression of time and the establishment of new, flexible methods of work, and the same time deeply effects articulation of new bodily practices."
} 
5.2 Relação entre arte, vida e política

Neste momento, buscamos refletir sobre as temporalidades em dança localizadas no contexto brasileiro. É no meio pelo qual elas se desdobram que sua dimensão política se revela. Observar o aspecto sociopolítico de temporalidades é relevante na medida em que ele está diretamente implicado nos discursos coreográficos, que se elaboram segundo o contexto e o período histórico em que o corpo e sua reflexão se situam.

A arte da dança no Brasil se vê às voltas com a velocidade dos acontecimentos políticos e econômicos que ocorrem no país, em meio ao desmonte de diversos setores que sofrem com cortes de verba na cultura, na saúde e na educação; diversas manifestações acontecem no país, não apenas no âmbito da cultura, mas também na luta por direitos humanos e trabalhistas em todos os setores.

Após o golpe contra a ex-presidenta Dilma Rousseff no governo, o índice de desemprego no Brasil atingiu em 2018 o maior nível da série histórica, com uma taxa média de 12,6\% de desemprego, segundo o Instituto Brasileiro de Geografia e Estatística (IBGE). Se, em 2014, no período de seu governo, a taxa era de $6,8 \%$ de desemprego no Brasil, hoje são 13 milhões de pessoas que estão desempregadas no país.

Embora observemos que, mesmo sem estrutura de planejamento e de investimento de recursos na área cultural do Brasil, o país apresenta alta qualidade de produções artísticas, o desejo de resistir ao desmonte da cultura emerge com relevância. Por exemplo, só em 2016 e 2017, a cidade de São Paulo teve o congelamento de $43,7 \%$ da verba da cultura, o que ocasionou o fechamento de diversos espaços culturais e gerou falta de perspectiva por parte dos trabalhadores, produzindo uma enorme dificuldade para que agentes culturais retomem suas atividades, além do cancelamento de inúmeros projetos e locais culturais da cidade.

Acontecimentos como esse, envolvendo mudanças, descontinuidades, rupturas e suspensões ajudam a pensar os acontecimentos vividos no Brasil. Esse é um dos exemplos de eventos que interferem na construção de temporalidades de um corpo em dança, porque envolvem ações políticas imprevisíveis que 
interrompem o planejamento do futuro antes imaginado, alterando a construção do presente de um artista.

Com o intuito de observar como as condições de trabalho do dançarino interferem na produção de suas temporalidades, traçamos uma breve comparação entre Brasil e França, levando em consideração as condições de trabalho do dançarino e do coreógrafo.

Embora as produções artísticas no Brasil sejam de alto nível, se comparadas às realizadas na França, algumas situações favorecem a produção de temporalidades em países que em certa medida investem na cultura a partir de uma estrutura de planejamento, atentando para o crescimento demográfico e para a oferta de empregos na área. Na França, por exemplo, teatros públicos, teatros privados e centros culturais contam com subsídios do governo para a manutenção de suas atividades culturais e sociais.

Os "intermittents du spectacle" constituem uma categoria assegurada dos artistas da cena, uma categoria que busca desenvolver e consolidar competências para a difusão de espetáculos. Há a valorização dos artistas por parte de uma política de governo que colabora para que esses possam exercer e continuar em sua profissão. Por exemplo, no Théâtre des Salinières, em Bordeaux, um teatro privado, onde acontecem 17 peças por ano (pelo menos 2 diferentes por semana), todos os atores trabalham em proporcionalidade, em uma espécie de rodízio, assegurando que todos os artistas recebam mesmo quando não estão em cena, de acordo com a instituição pública de empregos.

Os profissionais franceses da cena, tais como atores, dançarinos, coreógrafos, músicos, iluminadores e sonoplastas, por exemplo, podem receber um subsídio no período em que não exercem sua profissão. Mas não se trata de um "seguro desemprego", no qual não há perspectiva para que os profissionais retomem seus trabalhos, e sim de um estatuto que assiste a esses profissionais. Tanto os artistas com duração de contrato de trabalho determinado $\left(\operatorname{CDD}^{163}\right)$, quanto de

${ }^{163}$ Embora haja esses tipos de contrato de trabalho, há vantagens e desvantagens por parte dos dançarinos, conforme o depoimento de alguns: "O CDD de um ano de trabalho é problemático. Além do fato de que a cada ano seu futuro está em jogo. O que obriga você sempre a dar o melhor de si mesmo, mas também a ir além de suas possibilidades físicas e psicológicas no momento, ou seja, de colocar-se em perigo, o CDD coloca problemas na vida cotidiana. Assim, é muito difícil apresentar um CDD de un ano, de obter um crédito junto a uma instituição bancária". (RANNOU, ROHARIK, 2006, p. 28). 
contrato de duração indeterminado $\left(C D I^{164}\right)$, possuem acompanhamento do governo francês de forma planejada, seguido pelas instituições culturais e pela categoria dos "intermittents".

Outro exemplo: só em Bordeaux, por volta de 60 alunos passaram para o curso de Diploma de Estado de Professor de Dança Contemporânea 2018. Muitos não conseguiram passar, mas são pessoas interessadas que visualizam mercados de trabalho nesse ambiente. Este ano, em 2018, o festival de Avignon, fundado em 1947 pelo ator e diretor teatral francês Jean Vilar, comemorou 40 anos como festival de dança. Em 2017, a programação off foi composta por 1.000 espetáculos alternativos. Acontecem também, na França, muitos projetos e trabalhos por encomenda por parte de instituições privadas, embora haja diversos grupos artísticos que optam por não aceitar essa natureza de trabalho.

De todo modo, esses exemplos demonstram que o planejamento e a valorização da arte e da cultura colaboram para que os profissionais da área artística estejam assegurados e continuem no labor e na existência da profissão. Isso é radicalmente diferente das situações que descrevemos acima sobre o contexto brasileiro, em que as ações políticas, em vez de abrirem novos espaços e valorizarem a cultura, fecham espaços culturais, não preveem verbas para a manutenção de equipamentos culturais já existentes e cortam verbas para a cultura, alterando e até mesmo interrompendo a construção do presente de diversos artistas e profissionais do campo cultural.

O fluxo de acontecimentos imprevisíveis, que apresentam um futuro com poucas perspectivas de continuidade de trabalho, permite observarmos que as temporalidades do corpo dançante se implicam em descontinuidades, rupturas e suspensões. Temporalidades imbuídas de "vetores temporais de derivação" (FOUCAULT, 2008), vetores temporais que derivam de outros sem que se possa determinar uma ordem de sucessão, na qual a primeira advenha da segunda. Eles não se constroem por uma ordem cronológica de acontecimentos lineares, muito menos por uma ordem dedutiva ou de causalidade. Um modo temporal que não se

\footnotetext{
${ }^{164}$ Depoimento de um dançarino sobre o CDI: "Eu trabalhei no Ballet X. Esse balé passou por uma grande crise. O coreógrafo tem uma grande responsabilidade no desenrolar desse conflito [...]. Mas o fato de os dançarinos estarem no CDI também colaborou. Existiam situações fixas [...] Existia um ambiente ruim no nivel geral e sem renovação". (RANNOU, ROHARIK, 2006, p. 28). Trad. nossa a partir do original: "J'ai travaillé au Ballet X. Ce ballet a connu une grosse crise. Le chorégraphe a une grande responsabilité dans le déclenchement de ce conflit [...]. Mais le fait que les danseurs soient en $\mathrm{CDI}$ a aussi joué. II y a des situations figées, des danseurs qui sont là alors qu'ils n'ont aucune envie de travailler. II ya une mauvaise ambiance au niveau général et pas de renouvellement."
} 
distribui como uma longa cadeia de consequências, mas sim por "redistribuições recorrentes que fazem aparecer vários passados, várias formas de encadeamento, várias hierarquias de importância, várias redes de determinações, várias ideologias" (FOUCAULT, 2008, p. 5), à medida que o presente se modifica.

Essa viscosidade temporal está implicada em relações de trabalho que refletem a economia atual. Cada vez mais os trabalhadores da área artística, sem contar com o "solo tradicional que as instituições costumavam oferecer" (GIELEN, 2015, p. 38), se encontram de modo competitivo em uma cultura mundial de seleção e de concursos, quando eles acontecem. Mas há também associações de diferentes artistas que apresentam estratégias efêmeras, reunindo temporariamente outras pessoas para compor as necessidades de um projeto ou ação. Nesse contexto, "quando o projeto criativo termina, as relações são postas de lado. Elas estão finalizadas, mas potencialmente podem ser reativadas. Elas estão de certa forma suspensas" (GIELEN, 2015, p. 50).

Esse contexto integra a lógica neoliberalista em que vivemos, a qual, segundo o professor de política cultural Pascal Gielen, tem como base para todas as culturas o valor da moeda, do mercado e a acumulação do lucro, e que, por contradição, está constantemente criando leis para restringir a criação. Segundo o autor, na lógica capitalista, o mercado da arte precisa da mensuração para evitar riscos, quantificando tanto a produção de um artista, quanto o público que esse ou uma instituição envolve, por exemplo. Segundo ele, a mensuração serve a mecanismos de controle do sistema produtivo. Ao medirem-se segmentos e perfil de interesses, são traçadas metas para alcance de públicos e atividades. As condições de trabalho que, no passado, eram duráveis, hoje se apresentam como acordos empregatícios temporários que seguem uma mensuração de formalidades a cumprir em seus trabalhos. Tudo isso visando à produção: mesmo no tempo livre, diversos profissionais são sobrecarregados de modo a tornar inviável o tempo para a reflexão e criatividade. "O homem constantemente em rede e constantemente produzindo [...] está gradualmente sendo roubado de tudo o que permite a ele ser realmente criativo" (GIELEN, 2015, p. 107).

As temporalidades do corpo lidam, assim, com uma viscosidade temporal do próprio contexto em que esse corpo vive. Se não atentarmos para a percepção das diferenças no sistema político econômico, ou seja, "da reclamação da parte dos que não têm parte" (RANCIĖRE, 2017), é provável que, em vez de aprofundarmos a 
ação do qualificar, especificar, atentar às diferenças e às singularidades, a sobrevivência do artista tenda a beirar a indeterminação. De todo modo, diante dos diversos planos de acontecimentos, o artista em dança lida invariavelmente com estratégias que estão conectadas com a vida, com o contexto, com o ambiente e com o mercado da arte no qual ele se vê envolvido. 


\subsection{Temporalidades inscritas pela consciência}

Nos tempos duros que estamos passando com a realidade política, social e econômica do Brasil, vislumbrar situações melhores e possíveis nos impele a abordar o desejo e a imaginação, temporalidades emergentes que implicam a consciência e o inconsciente, ao criar situações que estimulam ações futuras.

A temporalidade, sob a ótica da esperança, lida com uma consciência dos desejos, que nunca desaparecem, e do "imaginar que traz à presença o que está ausente" ${ }^{165}$ (BOURIAU, 2003, p. 8). Essa temporalidade da consciência das necessidades e dos desejos se articula em camadas profundas. São temporalidades que implicam o "inconsciente" (GIL, 1997), trazem potências para a criação e para as ações no presente. Operam de modo diverso da temporalidade da expectativa, da espera de um futuro ainda não vivido, segundo métodos de produção dentro do capitalismo contemporâneo, como abordado no início deste capítulo.

Segundo Michel Bernard, "a temporalidade, trama de nossa corporeidade, se submete aos jogos imprevisíveis do imaginário que todo dançarino busca tornar visível" $^{166}$ (2001, p. 14). Para ele, a temporalidade em dança se constitui pela produção de ficção, ou seja, de uma invenção que coloca em jogo uma dinâmica sensorial e que possibilita a diversidade de materiais empregados para uma dança. Essa temporalidade é a todo momento construída pela urgência de necessidades imediatas do corpo e pelas percepções criadas por ele. Isso porque "o corpo dançante não cessa de se dissolver e se reconstituir na sucessão de seus instantes, no fluxo de uma temporalidade não controlável que tenta portanto imaginar e mesmo visualizar"167 (BERNARD, 2001, p. 80). A dança lida com o imaginário porque ele gera exploração de sensações e atua como dispositivo nas operações de sentido.

\footnotetext{
165 Tradução nossa a partir do original: "En son sens le plus general, l'imagination se définit comme la disposition à presenter les choses en leur absence. Imaginer, c'est amener à la présence ce qui est absent."

166 "Or, la temporalité radicale, trame de notre corporéité, n'est-elle pas ce que cherche à rendre visible, à orchestrer et, d'une manière générale, à soumettre aux jeux imprévisible de son imaginaire, tout danseur?"

${ }^{167}$ Tradução a partir do original: "Dès lors, le corps dansant ne cesse de se dissoudre et de se recontituer dans la sucession de ses instants, dans le flux d'une temporalité non maîtrisable qu'il essaie pourtant d'imager et même de visualiser : l'instant engendre la forme, et la forme fait voir l'instant."
} 
Segundo ele (1993), nós não imaginamos a partir da sensação - o imaginar está dentro da sensação. "A imaginação é o motor profundo da sensação, e por isso mesmo o motor da dança" (BERNARD, 2001, p. 61). O imaginar ou a produção da ficção está no interior do sistema sensorial que é trabalhado por um processo de simulação na descoberta de um objeto comum, identificável, num simulacro que aparece pelo desejo do sentir, como um tatear, muito mais do que querer identificar ou rotular.

Para o filósofo Michel Guérin (1995), a imaginação faz assumir um modo, uma maneira, um gesto inventado pelo gerenciamento das sensações que emergem de um contexto espacial: "não é a realidade que se transporta para a ficção, é a ficção que faz ver a realidade" ${ }^{168}$ (GUÉRIN, p. 74). A arte da dança vem do desejo compatível com um objetivo, apresenta um presente que é atenção composta por memória e projeções futuras.

O desejar e o imaginar situações correspondem às necessidades de um corpo e participam das expectativas futuras, são temporalidades que implicam uma consciência, "que interfere no jogo subtil e microscópio das pequenas percepções" (GIL, 2001, p. 159). Elas são justamente realizadas pelas noções temporais articuladas por um indivíduo ao longo de sua vida, a partir de suas experiências no ambiente em que vive.

Katz (1994) nos lembra que

a mente consciente estabelece relações com o mundo lá fora. Para tal, emprega, pelo menos, dois movimentos: usa o passado para realizar suas análises e, de posse delas, prepara suas ações futuras. Ou seja, a consciência se inscreve na temporalidade. (KATZ, 1994, p. 88)

Segundo ela, a consciência inscrita na temporalidade diz respeito à habilidade da criação, das escolhas e do encadeamento de conceitos elaborados por um sujeito: "para alguns cientistas cognitivos, a consciência se refere a uma situação de escolha entre sequências alternativas futuras" (KATZ, 1994, p. 87).

A consciência se inscreve na temporalidade ao envolver projeções futuras, mas essa consciência também advém da experiência vivida e da memória de ações passadas. A consciência se inscreve na temporalidade em dança porque é um

\footnotetext{
${ }^{168}$ Tradução nossa a partir do original: "Ce n'est pas la réalité qui se transporte dans la fiction, c'est la fiction qui fait voir la réalité".
} 
processo construído no qual o sujeito articula o tempo presente com o passado e com as projeções futuras, uma consciência que possibilita elaborar estratégias de criação.

Para o autor José Gil (2001), não apenas a consciência age em direção à identificação e à satisfação de necessidades, mas também o inconsciente tem o poder de transformação, o devir perceptivo e sensitivo de um corpo, que desorganizam a unidade da consciência. Embora Gil centre seus escritos na questão do espaço, para ele, as temporalidades ${ }^{169}$ podem ser percebidas na atmosfera de um encontro entre pessoas vindas de contextos diferentes. Por exemplo, uma tensão, um estado de tristeza ou outras percepções que, embora não sejam visíveis, são sentidas na atmosfera da relação. Trata-se de percepções temporais sutis que envolvem a consciência e o inconsciente.

Para o autor, o poder de transformação e de devir do corpo age nas afetividades $^{170}$ e projeções futuras, que são também organizadas pelo inconsciente, pois, "é através do inconsciente que o corpo age sobre a consciência" (GIL, 1997, p. 173). Os conteúdos psíquicos atuam tanto na consciência quanto no inconsciente, porque são portadores de energia e de afetos que se transportam para o movimento em um dinamismo próprio: "aquilo que se move no pensamento quando pensa o movimento" (2001, p. 165) traz uma presença, uma consciência.

O "sentir cinestésico - o movimento do corpo visto do interior - supõe um espaço topológico, não euclidiano onde as oposições não definem necessariamente distâncias" (GIL, 2001, p. 166). Segundo ele, os sentimentos, os desejos e a afetividade se misturam à consciência, provocando defasagens e atualizações necessárias. É nessa exploração de sensações dos movimentos cinestésicos que o corpo percebe o seu sentido e o seu contexto.

Segundo Gil, a dança, além de implicar a temporalidade da consciência, também envolve "o inconsciente que age em direção à satisfação de necessidades" (GIL, 1997, p. 187). O inconsciente põe em fluxo o presente, o passado e o futuro de modo indeterminado. Nesse sentido, o imaginar e o desejar participam do inconsciente. Segundo ele, é através do inconsciente que o corpo age sobre a

\footnotetext{
${ }^{169}$ Entendimento de temporalidades segundo a entrevista realizada com o professor e filósofo José Gil em 20 de abril de 2018 em Portugal.

170 Tradução nossa a partir do original : "A afectividade é o modulador global que integra uma multiplicidade de segmentos numa sequência individuada: tem a propriedade de abarcar um conjunto numa totalidade - uma forma - singular" (GIL, 1997, p. 42).
} 
consciência, o "insconsciente do corpo não é mais do que o resultado da inscrição, no interior como na pele, de conteúdos psíquicos - imagens, afectos, pensamentos - que não encontraram expressão verbal" (GIL, 1997, p. 183).

De todo modo, a "narrativa" que o dançarino constrói lida com as estruturas imaginadas ou desejadas pelo inconsciente. Diferentemente de um tempo objetivo dado de antemão, o corpo em dança constrói temporalidades imprevisíveis, não controladas totalmente. A prática do corpo lida com o inconsciente e com a consciência a partir das experiências vividas, o que promove entendimentos temporais os quais entrecruzam presente, passado e futuro de uma maneira não linear entre esses registros temporais.

Além de participar de projeções futuras, e de um presente daquilo que é necessário, o desejar e o imaginar partem também da memória que está "entre as artes do pensar, envolvidas especialmente na promoção das qualidades que hoje reverenciamos sob os nomes de imaginação" (CARRUTHERS, 2011, p. 34). A memória agencia imagens e esquemas mentais imaginativos. "Como de costume as imagens da memória não são ilustradas nem são claramente descritas. Nós temos de construir nossas próprias regras"171 (YATES, 2010, p. 117).

Os desejos se inscrevem tanto na consciência quanto no inconsciente. São temporalidades que se desdobram como potência ao experimentar agenciamentos que se atualizam constantemente em um processo de dança. De acordo com Gil (2001), o desejo cria agenciamentos, mas o movimento de agenciar abre-se sempre em direção a novos "agenciamentos", ou seja, "criar novas conexões entre materiais heterogêneos, novos nexos, outras vias de passagem da energia, ligar, pôr em contacto [...] tal é o que significa agenciar" (GIL, 2001, p. 70).

Para criar novos agenciamentos corporais, torna-se necessário o desejar, contudo, criar novos agenciamentos implica também se desviar de percursos habituais. A consciência envolve o estado presente de atenção no contexto em que se vive, as percepções que o corpo em dança elabora e a sua memória. A temporalidade inscrita na consciência diz respeito ao pensamento, à presença de diferentes estados corporais, podendo revelar urgências, prorrogações, alegrias, tristezas, medo, contemplações, fadiga etc. Em suma, trata-se de temporalidades que intervêm na dramaturgia do corpo que dança.

\footnotetext{
171 Tradução nossa a partir do original: "As usual the memory images are not illustrated nor are they very clearly described. We have to construct our own from the rules".
} 


\section{Conclusão}

Ao longo de quatro anos desta pesquisa, investiguei certos entendimentos de temporalidades e suas relações com o fazer coreográfico, com o objetivo de refletir sobre noções temporais que mobilizam a criação em dança.

A principal hipótese é de que temporalidades viabilizam uma dramaturgia do corpo em dança. Na trajetória desta pesquisa, distintas temporalidades são percebidas em obras coreográficas, assim como certos parâmetros temporais do movimento.

Desenvolvo o entendimento de que "temporalidades" correspondem ao processo de composição, organização e estruturação de procedimentos espaçotemporais de uma concepção coreográfica, desde sua composição até sua apresentação, contribuindo assim para as coerências que estruturam uma dramaturgia do corpo.

Se toda transformação implica um processo temporal, o corpo é ele mesmo trama de temporalidades. A todo momento o corpo processa experiências temporais nas elaborações e atualizações de informações em relação ao ambiente de existência, ou seja, temporalidades estão relacionadas ao corpo e ao espaço.

Essas temporalidades do corpo desdobram ainda outras temporalidades: as que se constituem como procedimentos espaçotemporais em uma obra de dança. Um processo no qual são criadas e combinadas as variações temporais de um trabalho cênico. Trata-se de temporalidades observadas por problemáticas artísticas produzidas pelos movimentos dos corpos na elaboração de um pensamento cênico.

A metodologia foi realizada a partir de exemplos de diferentes obras coreográficas, tais como: Danças Passageiras (2013), Esculturas Breves (2015), Brevidades (2016) e pela experimentação do processo de criação intitulado Nó(s) (2016). Nas temporalidades percebidas em Danças Passageiras, concebida pela coreógrafa brasileira Zélia Monteiro, observamos estratégias de permanências no instante, temporalidades métricas irregulares, a memória e fluxos imagéticos como noções temporais construídas e combinadas que dão a ver uma dramaturgia. Em Esculturas Breves e Brevidades, concebidas pela coreógrafa brasileira Helena Bastos, observamos temporalidades como um processo transversal de relações que 
qualifica modos de agir. Trata-se de relações que se processam em diferentes níveis e sentidos pelo compartilhamento de ações corporais suspensas e dilatadas, temporalidades que incluem a gravidade, a escuta e a prontidão em meio ao fluxo da cidade. No processo de criação de Nó(s), do qual participei como coreógrafa, construímos um trabalho artístico a partir de dados temporais que se valeram de procedimentos tais como: temporalidades elásticas e combinação de certos parâmetros temporais do movimento, como o fluxo, o uníssono, a gravidade e a repetição. Com esses exemplos analisados, observo a criação de dados temporais que qualificam modos de agir, portam singularidades e revelam estratégias de criação, confirmando nossa ideia de que temporalidades permitem a elaboração de um pensamento cênico e viabilizam uma dramaturgia de dança.

Os exemplos das obras coreográficas abordadas na pesquisa permitem observar que as temporalidades compõem uma dramaturgia, visto que essa trata da coerência e da organização interna que estruturam uma obra de dança. Cada um desses trabalhos porta questionamentos e singularidades, na medida em que apresenta procedimentos temporais específicos que concretizam um determinado pensamento artístico.

Abrangendo os parâmetros temporais do movimento como um dos prismas de temporalidades, selecionei o fluxo, o uníssono, a gravidade, a repetição, a memória e a defasagem para a reflexão na pesquisa. A análise de tais parâmetros é observada em certas abordagens coreográficas, possibilitando examinar como cada obra explora de maneira diferente esses parâmetros.

Os parâmetros temporais do movimento foram analisados com exemplos de obras coreográficas que ressaltam cada um deles, como o fluxo e a simultaneidade observados em So Blue (2012), concebido pela coreógrafa canadense Louise Lecavalier; o uníssono trabalhado na obra Tempo 76 (2007), da coreógrafa francesa Mathilde Monnier e na obra Fase (1982), da coreógrafa belga Anne Teresa de Keersmaeker; e a subversão da gravidade em Men Walking Down on the Side of a Building (1970), da coreógrafa norte-americana Trisha Brown.

Os parâmetros temporais do movimento podem ser pensados no âmbito da construção de um espetáculo, na prática de dança e no contexto de um curso de dança, contudo, o estudo de cada uma dessas atividades não revelará as mesmas funções e sentidos. Desse modo, abordo também os parâmetros temporais do movimento selecionados na presente pesquisa analisando-os no âmbito de cursos 
de dança, com exemplos que possibilitam observar que eles agem como procedimentos metodológicos para o estudo do movimento.

Outra faceta de temporalidades é a sua dimensão política. Essa noção de tempo, que qualifica modos de agir e revela elaborações temporais construídas em um trabalho artístico, está diretamente vinculada aos aspectos sociopolíticos de um ambiente e aos questionamentos temporais implicados no mercado cultural, na medida em que esses reconfiguram a experiência da criação.

Constatamos ainda que as temporalidades em dança contemporânea vêm se expandindo da segunda metade do século XX até os dias de hoje. Testemunhamos, atualmente, um aumento na complexidade das sobreposições e simultaneidade de diferentes qualidades espaçotemporais, nas abordagens de criação em dança. Ou seja, verificamos, com os exemplos, uma expansão da contaminação de diferentes procedimentos temporais entre linguagens artísticas e formatos de apresentação. As temporalidades permeiam outras linguagens e formatos artísticos, contribuindo para uma dramaturgia do corpo.

Contudo, o processo de composição, organização e estruturação de procedimentos espaçotemporais elaborados pelo corpo que dança apresenta temporalidades específicas desse campo do conhecimento. Os fatores temporais estão diretamente vinculados às ações corporais que, por sua vez, nunca cessam de se transformar. Além disso, o procedimento diz respeito ao modo de composição de toda uma concepção cênica, a combinação dos diversos elementos de uma dramaturgia de dança implica no como eles são agenciados, nesse sentido as temporalidades modificam toda uma dramaturgia.

A análise, discussão e os dados observados não esgotam, evidentemente, a pesquisa acerca das questões temporais em dança; ao tomar como base outras pesquisas sobre o assunto, considero que o estudo sobre o tempo no fazer coreográfico pode ser desdobrado também sob outros aspectos.

Acredito, todavia, que esta investigação pode contribuir para a prática profissional de dançarinos, coreógrafos, performers, atores e professores das artes cênicas que lidam com o corpo e o movimento. Isso porque as temporalidades implicam a seleção e as estratégias de uma criação. Identificar e reconhecer, bem como ter consciência dos fatores temporais de um trabalho artístico são gestos que colaboram para as coerências de uma dança, potencializando o que o artista intenta enunciar a partir do corpo numa proposição cênica. 


\section{Referências bibliográficas}

ABBAGNANO, Nicola. Dicionário de Filosofia. $2^{\circ}$ Ed. Trad. Alfredo Bosi. São Paulo: Martins Fontes, 1998.

ADOLPHE, Jean-Marc. La dramaturgie est un exercice de circulation pour tenir le monde a l'écart. In: Nouvelles de Danse $n^{\circ} 31$, Bruxelles: Contredanse, 1997. pp. 3134.

AGAMBEN, Giorgio. O que é o contemporâneo e outros ensaios. Ed. Trad. Vinícius Nicastro Honesko. Chapecó, SC: Argos, 2009.

AMORIM, Gícia; BERGSON, Queiroz. Merce Cunningham: Pensamento e técnica. Lições de Dança 2. Rio de Janeiro: UniverCidade Editora, 2000. pp. 81-109.

AZEVEDO, Francisco Ferreira dos Santos. Dicionário analógico da língua portuguesa: ideias afins / thesaurus. 2. ed. atual. Rio de Janeiro: Lexikon, 2010.

BACHELARD, Gaston. A dialética da Duração. Trad. Marcelo Coelho. São Paulo: Editora Ática, 1988.

BARDET, Marie. Pensar con mover: Un encuentro entre danza y filosofia. Argentina: Editora Cactus, 2012.

BASTOS, Maria Helena F. A. Dança: Fronteiras uma ponte entre a prática e teoria, num diálogo entre arte e ciência. Dissertação (Mestrado). PUC-SP, São Paulo, 1999.

. Variâncias: O corpo processando identidades provisórias. Tese (Doutorado) PUC-SP, São Paulo, 2003. 
. DançaCorpos ViraCorpos Trânsitos Compartilhados. In: Revista Sala Preta, Revista do PPG da Faculdade de Artes Cênicas da ECA/USP. São Paulo, n 10. 2010. pp.155-162.

- Musicanoar Corpo e Cidade: Moveres entre aproximações e distanciamentos. São Paulo: Cooperativa Paulista de Dança, 2015.

. Corpo sem vontade. São Paulo: Cooperativa Paulista de Dança, 2017.

BERGSON, Henri. Durée et Simultanéité: A propos de la théorie d'Einstein. 7. Ed. Press Universitaires de France: Paris, 1968.

. Matéria e Memória: Ensaio sobre a relação do corpo com o espírito. Trad. Paulo Neves da Silva. $4^{\circ}$ ed. São Paulo: Martins Fontes, 2010.

BERNARD, Michel. De la création choréographique. Paris: CND, 2001.

. Sens et Fiction, ou les effets étranges de trois chiasmes sensoriels. In: Nouvelles de Danse $n^{\circ}$ 17. Bruxelas: Contredanse: 1993, pp. 56-64.

BERTHOZ, Alain. Lições sobre o corpo, o cérebro e a mente: as raízes das ciências do conhecimento no Collège de France. São Paulo: EDUSC, 2005.

BOISSEAU, Rosita. Trisha Brown: No limits. In: Nouvelles de danse $n^{\circ} 70$, Bruxelles: Contredanse, 2017. pp. 16-17.

BOSSEUR, Jean-Yves. Du Jeu à l'écrit ou de l'écrit au jeu. L'improvisation en musique contemporaine. In: Nouvelles de Danse n³0, Bruxelles: Contredanse, 1997, pp.51-58.

BOURIAU, Christophe. Qu'est-ce que l'imagination? Paris: Chemins Philosophiques, Librairie Philosophique, 1975. 
BRITTO, Fabiana Dultra. Temporalidade em Dança: parâmetros para uma história contemporânea. Belo Horizonte: FID Editorial, 2008.

CARRUTHERS, Mary. Machina memorialis: Méditation, rhétorique et fabrication des images au Moyen Âge. França: Gallimard, 2002.

CASPÃO, Paula. Stroboscopic Stutter: On The Not-Yet-Captured Ontological Condition Of Limit-Attractions. In: LEPECKI, André; JOY, Jenn. (Ed.) Planes of composition. Dance, Theory and the Global. New York: Seagull Books, 2009. pp. 123-129.

COOLS, GUY. De la dramaturgie du corps en danse. 2005. Disponível em: https://www.erudit.org/fr/revues/jeu/2005-n116-jeu1111093/24810ac/

COPELAND, Roger; CUNNINGHAM, Merce. The Modernizing of Modern Dance. Nova York: Routledge, 2004.

CRÉMÉZI, Sylvie. La Signature de la Danse Contemporaine. Paris: Editions Chirons, 1997.

CVEJIC, Bojana. During and After Performance: Processes, Caesuras, and Resonances. In: Choreographing Problems. Expressive Concepts in European Contemporary Dance and Performance. New York: Macmillan, 2015. pp. 195-214.

DELEUZE, Gilles. Conversações. 3. Trad. Peter P. Pelbart. São Paulo: Editora 34 (Coleção Trans), 1992.

- Mil Platôs Capitalismo e Esquizofrenia. Vol. 1. Trad. Aurélio Guerra Neto e Celia Pinto Costa. São Paulo: Editora 34, 1995.

. Diferença e repetição. Trad. Luiz Orlandi, Roberto Machado. Rio de Janeiro: Graal, 1988. 
DIDI HUBERMAN, Georges. A imagem sobrevivente: História da arte e tempo dos fantasmas segundo Aby Warburg. Rio de Janeiro, Contraponto, 2013.

ELIAS, Norbert. Sobre o tempo. Trad. Vera Ribeiro. Rio de Janeiro: Jorge Zahar, 1998.

FABRI, Véronique. Danse et Philosophie: Une pensée en construction. Paris: L'Harmattan, 2007.

FERNANDES, Ciane. O corpo em Movimento: o sistema Laban/Bartenieff na formação e pesquisa em artes cênicas. São Paulo: Annablume, 2006.

FERREIRA, Aurélio B. H. Novo Dicionário da Língua Portuguesa. Rio de Janeiro: Nova Fronteira, 1986.

. Pequeno Dicionário Brasileiro da Língua Portuguêsa. São Paulo: Companhia Editora Nacional, 1972.

FILHO, Clóvis de Barros. Tempo e temporalidades. 2016. Disponível em: https://www.youtube.com/watch?v=yKwEKVpAo0c.

FONTAINE, Geisha. Les danses du temps. Centre National de la danse. França: Pantin, 2004.

. Conferência em CNDC d'Angers. 2016. Disponível em:

http://www.milleplateauxassocies.com/ouvertures/conferences/

FOSTER, Susan Leight. Corporealities: Dancing Knowledge culture and power. Londres: Routledge, 1996.

. Worlding Dance. Nova York: Palgrave Macmillan, 2009.

FOUCAULT, Michel. Vigiar e Punir: Nascimento da Prisão. Trad. Raquel Ramalhete. Rio de Janeiro: Vozes, 1987. 
- Arqueologia do Saber. Trad. Luiz Felipe Baeta Neves. Rio de Janeiro: Forense Universitária, 2008.

FRIMAT, François. Qu'est-ce que la danse contemporaine? Paris: Press Universitaires de France, 2010.

GIELEN, Pascal. Criatividade \& Outros Fundamentalismos. São Paulo: Annablume, 2015.

GIL, Fernando. Encycopedia Einaudi. vol. 29. São Paulo: Imprensa Nacional Casa da Moeda, 1993.

GIL, José. Movimento Total: O corpo e a dança. Trad. Miguel Serras Pereira. Lisboa: Relógio D'Água Editores, 2001.

- Metamorfoses do Corpo. $2^{\circ}$ ed. Lisboa: Relógio D'Água Editores, 1997.GREINER, Christine; KATZ, Helena. Por uma teoria do Corpomídia. In: O Corpo: pistas para estudos indisciplinares. São Paulo: Annablume, 2005.

O corpo em crise: novas pistas e o curto-circuito das representações. São Paulo: Annablume, 2010.

GREINER, Christine. Indagações sobre o que pode (ser) um processo. In: GREINER, Christine et al. (Org.) Cartografia. Rumos Itaú Cultural Dança 2009-2010, Criações e Conexões. São Paulo: Itaú Cultural, 2010. pp. 79-84.

GUATTARI, Félix. Micropolítica Cartografias do Desejo. Petrópolis: Vozes, 1996.

GUÉRIN, Michel. Philosophie du Geste. Paris: Actes Sud, 1995.

HERCOLES, Rosa. Epistemologias em Movimento. In: Revista Sala Preta. Revista do PPG da Faculdade de Artes Cênicas da ECA/USP. São Paulo, nº 10. 2010. pp. 199-203. 
. Formas de Comunicação do Corpo - novas cartas sobre a dança. Tese (Doutorado) Universidade Católica de São Paulo - PUC-SP, São Paulo, 2005.

HEWITT, Andrew. Social Choreography: ideology as performance in dance and everyday movement. Durham and London: Duke University Press, 2005.

HORST, Louis. Les Règles Fondamentales de la Composition - Condition Préalable à n'importe quelle chorégraphie. Trad. Carole Guth. In: Nouvelles de Danse. La Composition, Bruxelles, n 36/37: Contredanse, 1998, pp. 46-50.

HUMPRHEY, Doris. Liste de Contrôle. In: Nouvelles de Danse La Composition, Bruxelles, no 36/37: Contredanse, 1998, pp.51-64.

JAPIASSÚ, Hilton; MARCONDES, Danilo. Dicionário básico de Filosofia. $5^{\circ}$ Ed. Rio de Janeiro: Jorge Zahar, 2008.

JOHNSON, Mark. The meaning of the body: aesthetics of human understanding. Chicago \& London: The University of Chicago Press, 2007.

JOHNSTONE, Maxine Sheets. The phenomenology of dance. Estados Unidos: The University of Wisconsin Press Madison and Milwaukee, 1966.

KATZ, Helena. Por uma dramaturgia que não seja uma liturgia da dança. In: Revista Sala Preta. São Paulo: Universidade de São Paulo, 2010, pp. 163-167.

. Um, dois, três. A dança é o pensamento do corpo. Tese (Doutorado) PUCSP, São Paulo, 1994.

KERKHOVE, Marianne Van. Le processus dramaturgique. Nouvelles de danse, Dossier Danse et Dramaturgie, n. 31, p. 18-23, Bruxelas: Contredanse, 1997. 
KOURLAS, Gia. Review: Louise Lecavalier is a typhoon of phisicality in "So Blue". 2015. Disponível em: https://www.nytimes.com/2015/09/11/arts/dance/review-louiselecavalier-is-a-typhoon-of-physicality-in-so-blue.html

KUYPERS, Patricia. Introduction. In: Nouvelles De Danse. La Composition, Bruxelles, n 36/37: Contredanse, 1998. p. 5-10.

KUNST, Bojana. On the Temporality of Making. 2012. Disponível em: http://www.manifestajournal.org/issues/regret-and-other-back-pages/project-horizontemporality-making\#

How time can dispossess on duration and movement in contemporary performance. $2010 . \quad$ Disponível em: https://kunstbody.wordpress.com/2010/12/10/how-time-can-dispossess-on-durationand-movement-in-contemporary-performance/

LABAN, Rudolf. The language of movement: a guidebook to choreutics. British: Macdonald and Evans Ltd., 1966.

LECAVALIER, Louise. So blue. 2015 Disponível em: https://www.nytimes.com/2015/09/11/arts/dance/review-louise-lecavalier-is-atyphoon-of-physicality-in-so-blue.html

LEPECKI, André. Planes of Composition Dance, Theory and The Global. Edited by André Lepecki and Jenn Joy, New York: Seagull Books, 2009

. Cartografia: Rumos Itaú Cultural Dança 2009-2010, Criações e Conexões. GREINER, Christine et al. (Org.). São Paulo: Itaú Cultural, 2010. pp. 13-20. . Singularities Dance in the age of Performance. New York: Routledge, 2016. 
Repensar la dramaturgia: Errancia y transformación. Espanha: CENDEAC Editorial: Centro de Documentación y Estudios Avanzados de Arte Contemporaneo, 2011.

. Exhausting Dance: Performance and the politics of movement. New York e Londres: Routledge Taylor \& Francis Group, 2006.

LINS, Daniel. "Deleuze: o surfista da imanência". In: LINS, Daniel; Gil, Jose (Org.). Nietzsche/Deleuze: Jogo e música. Rio de Janeiro:Forense Universitária; Fortaleza, 2008. pp. 53-75.

LOUPPE, Laurence. Poética da Dança Contemporânea. 1. Ed. Lisboa : Orfeu Negro, 2012.

- Qu'est-ce qui est politique en danse? In. Nouvelles de Danse. $\mathrm{n}^{\circ} 30$, Bruxelas: Contredanse: 1997, pp. 36-40.

- Voyage dans l'oeuvre de Trisha Brown. In: Nouvelles de Danse $\mathrm{n}^{\circ} 17$. Bruxelas: Contredanse: 1993, pp. 13-18.

. Poétique de la danse contemporaine: la suite. Bruxelas: Contredance, 2007.

- Quelques Visions Dans Le Grand Atelier. In: Nouvelles de Danse. La Composition, Bruxelles : n 36/37 Contredanse, 1998. p.11-32.

Avant-Propos Émergence Des Corps Critiques. In: Poétique de la danse contemporaine: la suite. Bruxelles : Contredanse, 2004.

MANNING, Erin. The elasticity of the almost. In: Planes of Composition. New York: Seagull Books, 2009, pp.107-121.

MARTINS, Cleide. Improvisação Dança Cognição Os Processos de Comunicação no Corpo. Tese (Doutorado) PUC/SP, São Paulo: 2002. 
MASSI, Domenico De Masi; PEPE, Dunia. As palavras no tempo: vinte e seis vocábulos da Encyclopédie reescritos para o ano 2000. Rio de Janeiro: Editora José Olympio Ltda, 2003.

MONNIER, Mathilde. Tempo 76. Dossie Pedagógico. 2008. Disponível em: : http://www.cndp.fr/crdp-reims/poletheatre/service_educatif/mathilde_monnier.pdf

MONTEIRO, Marianna. Noverre: Cartas sobre a Dança. São Paulo: Edusp, 1998.

MONTEIRO, Zélia. Sobre o imprevisível. São Paulo: $7^{\circ}$ edição do Fomento à Dança, 2008.

. ENCICLOPÉDIA Itaú Cultural de Arte e Cultura Brasileiras. São Paulo: Itaú Cultural, 2019. Disponível em: http:enciclopedia.itaucultural.org.br

PAIS, Ana. O Discurso da Cumplicidade: Dramaturgias Contemporâneas. $2^{\circ}$ Edição. Edições Colibri. Lisboa: 2016.

PALLOTTINI, Renata. Introdução à dramaturgia. São Paulo: Editora Ática, 1988.

PAVIS, Patrice. Diccionario del teatro. Trad. Jaume Melendres. Barcelona: Paidós Ibérica S.A, 1998.

PRIGOGINE, Ilya; STENGERS, Isabelle. Entre el tempo y la eternidade. Buenos Aires: Alianza Editorial, 1991.

RANCIĖRE, Jacques. O espectador emancipado. São Paulo: Martins Fontes, 2014.

- 0 Dissenso. Disponível em Territórios da filosofia: https://territoriosdefilosofia.wordpress.com/2014/10/19/o-dissenso-jacques-ranciere/ 
. O Desentendimento: política e filosofia. $2^{\circ}$ Edição. Coleção TRANS. São Paulo: Editora 34, 2018.

. En quel temps vivons-nous? Conversation avec Eric Hazan. Paris: La Fabrique éditions, 2017.

RANNOU, Janine; IONELA, Roharik. Les Danseurs: Un métier d'engagement. Paris: La Documentation française, 2006.

RIBEIRO, Mônica. Cognição e afetividade na experiência do movimento em dança: conhecimentos possíveis. In: KATZ, Helena; GREINER, Christine. (Org.) Arte \& Cognição. São Paulo: Annablume, 2015.

ROUX, Céline. Danse(s) performative(s). Paris: L'Harmattan, 2007.

SANTANA, Ivani. Corpo Aberto: Cunningham, dança e novas tecnologias. São Paulo: Educ, 2002.

SENNETT, Richard. O Artífice. Trad. Clóvis Marques. Rio de Janeiro: Record, 2009. . Juntos. Trad. Clóvis Marques. Rio de Janeiro: Record, 2012

SIMONDON, Gilbert. Imagination et Invention. França: La Transparence, 2008.

SUQUET, Annie. O corpo dançante: um laboratório da percepção. In: História do Corpo - 3. As Mutações do olhar: O século XX. Org. Jean-Jacques Courtine. Petrópolis: Editora Vozes, 2008. pp. 509-540.

VIANNA, Klauss. A Dança. São Paulo: Summus, 2005.

WARBURG, Aby. Histórias de fantasma para gente grande: escritos, esboços e conferências. Org. Leopoldo Waizbort. Trad. Lenin Bicudo Bárbara. $1^{\circ}$ Ed. São Paulo: Companhia das Letras, 2015. 